\title{
Nitretação e Carbonitretação por Plasma em aços inoxidáveis e suas influências nas resistências à corroção e ao desgaste
}

\author{
Antonio Maia de Oliveira
}

USP/IFSC/SBI

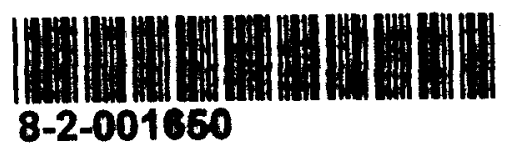

Tese apresentada à Área Interunidades em Clência e Engenharia de Materiais, da Universidade de São Paulo, para obtenção do título de Doutor em Clências e Engenharia de Materiais.

Orientador: Prof. Dr. Luiz Carlos Casteletti 
Oliveira, Antonio Maia de

"Nitretação e Carbonitretação por Plasma em aços e suas influências nas resistências à corroção e ao desgaste" Antonio Maia de Oliveira - São Carlos, 2005

Tese (Doutorado) - Interunidades Ciência e Engenharia de Materiais da

Universidade de São Paulo, 2005 - páginas: 117

Área: Ciência e Engenharia de Materiais

Orientador: Prof. Dr. Luiz Carlos Casteletti

1. Nitretação e Carbonitretação por Plasma, Aços Inoxidáveis, microdesgaste abrasivo, corrosão por pites.

1. Título 
Universidade de São Paulo

Ciência e Engenharia de Materiais

Fone (16) 3373-9589 - Fax (16) 3373-9777

MEMBROS DA COMISSÃO JULGADORA DA TESE DE DOUTORADO DE ANTONIO MAIA DE OLIVEIRA APRESENTADA A ÁREA INTERUNIDADES CIENCIA E ENGENHARIA DE MATERIAIS, UNIVERSIDADE DE SÃO PAULO, EM 14/01/2005.

COMISSÃO JULGADORA:

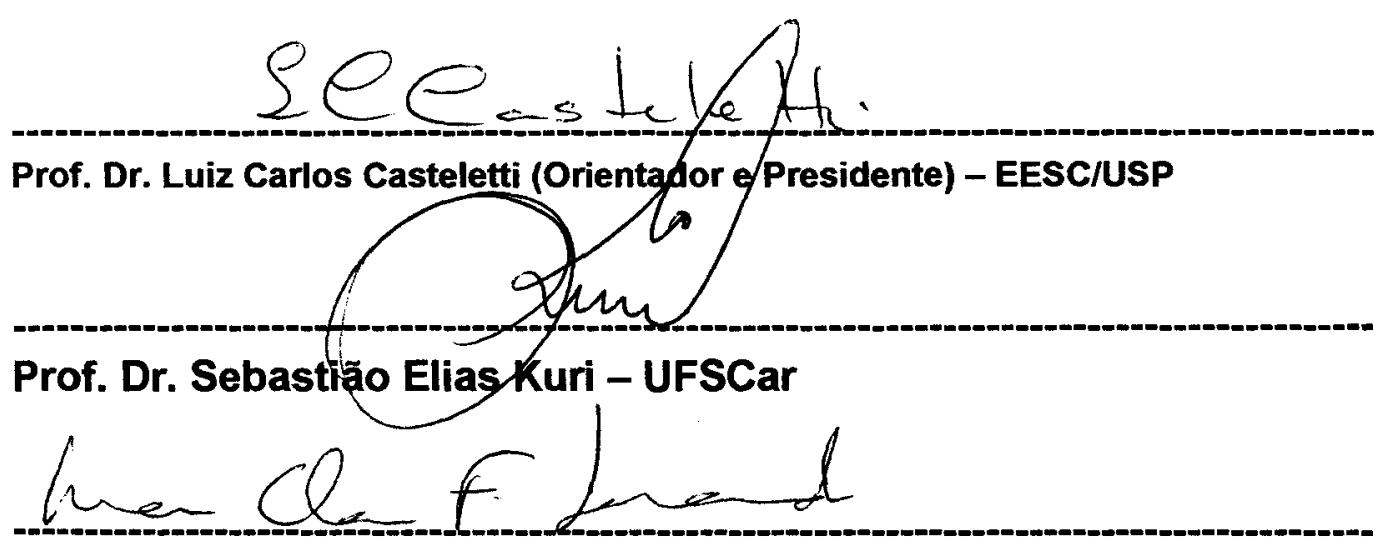

Profa. Dra. Maria Clara Filippini lerardi - UNICAMP

Profa. Dra. Lauralice de Campos Franceschini Canale - EESC/USP

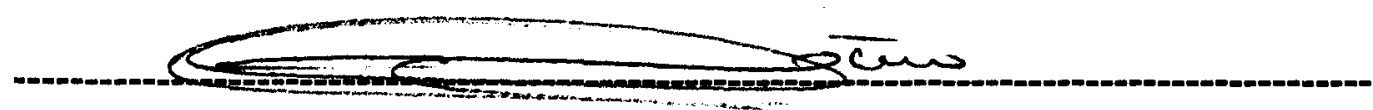

Prof. Dr. Artur de Jesus Motheo - IQSC/USP

USP - Educação para o Brasil

IFSOUSF 
À minha esposa Mírian e aos meus três filhos Ramon, Rômulo e Filipe pelo apoio e compreensão. 


\section{AGRADECIMENTOS}

Ao professor Dr. Luiz Carlos Casteletti, pela orientação, pelo apoio, amizade e incansável e valiosa orientação durante a realização deste trabalho.

A todos os amigos e colegas da pós-graduação que direta ou indiretamente contribuíram para a conclusão deste trabalho.

Aos funcionários do Departamento de Materiais, Aeronáutica e Automobilísticas da EESC-USP, pela amizade, apoio e colaboração no decorrer deste trabalho.

Aos técnicos e professores do Departamento de Materiais, Aeronáutica e Automobilísticas da EESC-USP pela amizade e compreensão.

A CAPES e ao CEFET-Ma, pelo apoio financeiro durante o meu curso de doutorado. 


\section{SUMÁRIO}

LISTA DE FIGURAS i

LISTA DE TABELAS iv

LISTA DE ABREVIATURAS, SIGLAS E SIMBOLOS v

RESUMO vi

SUMMARY vii

$\begin{array}{ll}\text { 1- INTRODUÇÃO } & 01\end{array}$

2- REVISÃO BIBLIOFRÁFICA 05

$\begin{array}{ll}\text { 2.1- AÇOS INOXIDÁVEIS } & 05\end{array}$

2.1.1- Aços inoxidáveis austeníticos $\quad 06$

$\begin{array}{ll}\text { 2.1.2- Aços inoxidáveis ferriticos } & 07\end{array}$

2.1.3- Aços inoxidáveis duplex $\quad 08$

2.2- NITRETAÇÃO E CARBONITRETAÇÃO POR PLASMA 10

2.2.1- Reações que ocorrem no interior do plasma 14

2.2.2- Nitretação e carbonitretação por plasma de aços inoxidáveis 16

2.2.3- Fases presentes nas camadas nitretadas e carbonitretadas 17

2.2.4- Difusão do nitrogênio na austenita, ferrita e na camada de compostos $\quad 20$

2.2.5- Vantagens e limitações da nitretação e carbonitretação por plasma

2.3- CORROSÃO DOS AÇOS INOXIDÁVEIS 22

2.3.1- Aspectos gerais da corrosão nos aços inoxidáveis 24

$\begin{array}{ll}\text { 2.3.2- Passivação } & 25\end{array}$

2.3.3- Formação de pites 30

2.3.4- Ocorrência dos pites 31

2.3.5- Pites metaestáveis e estáveis $\quad 32$

2.4- DESGASTE MICROABRASIVO DE REVESTIMENTOS DUROS 33

2.4.1- Mecanismos de desgaste microabrasivo 34 
3.1 - EQUIPAMENTO PARA NITRETAÇÃO E CARBONITRETAÇÃO

3.3.1- Seccionamento das amostras a serem tratadas

3.3.2- Lixamento e polimento das amostras

3.3.3- Limpeza das amostras 48

3.3.4- Tratamentos de Nitretação e Carbonitretação por plasma 49

3.3.5- Caracterização das amostras 50

3.3.6- Ensaio de Microdureza

3.3.7- Ensaios de Desgaste

3.3.8- Microscopia Eletrônica de Varredura (MEV) e EDX 52

3.3.9- Curvas de polarização anódicas

3.3.10- Difração de raios $X$

4.1- Análises Micrográficas e Medidas de Microdurezas das

Camadas Produzidas

4.1.1- Amostras Nitretadas

4.1.2- Amostras Carbonitretadas

4.2- Microscopia Eletrônica de Varredura e Microanálises por EDX

4.2.2- Amostras Carbonitretadas 
4.5- Análise da Resistência à Corrosão

4.5.1- Amostras Nitretadas 93

4.5.2- Amostras Carbonitretadas $\quad 97$

$\begin{array}{ll}\text { 5- CONCLUSÕES } & 104\end{array}$

6- SUGESTÕES PARA TRABALHOS FUTUROS 106

$\begin{array}{ll}\text { 7- REFERÊNCIAS BIBLIOGRÁFICAS } & 107\end{array}$

$\begin{array}{lr}\text { 8- TRABALHOS PUBLICADOS } & 114\end{array}$ 


\section{LISTA DE FIGURAS}

Figura 01 - Reações superficiais que ocorrem durante a nitretação por plasma

Figura 02- Diagrama de equilíbrio Fe- N

Figura 03- Representação esquemática de formação e crescimento do filme de óxido em meio aquoso ou meio atmosférico

Figura 04- Curva de polarização anódica esquemática para aços inoxidáveis

Figura 05- Mapa do mecanismo de desgaste microabrasivo para aço ferramenta usando esfera de aço

Figura 06- Diagrama esquemático mostrando, (a) equipamento experimental e (b) detalhes da interface de contato e alimentação do abrasivo

Figura 07- Diagrama esquemático mostrando a geometria da calota formada pelo ensaio microabrasivo com uma esfera de raio $(R)$,

(a) no substrato e (b) na camada

Figura 08- Fluxograma da seqüência dos procedimentos experimentais realizados neste trabalho

Figura 09- Esquema do equipamento de nitretação e carbonitretação por plasma utilizados nos experimentos

Figura 10- Foto do equipamento de nitretação e carbonitretação por plasma utilizado no trabalho

Figura 11- Micrografias óticas e curvas de microdurezas para o aço AISI $316 \mathrm{~L}$ nitretado a diferentes temperaturas

Figura 12- Micrografias óticas e curvas de microdurezas para o aço super duplex ASTM A890 Gr 5A nitretado a diferentes temperaturas

Figura 13- Micrografias óticas e curvas de microdurezas para o aço AISI 409 nitretado a diferentes temperaturas

Figura 14- Espessura da camada nitretada em função da temperatura (a) AISI 316L e (b) super duplex ASTM A890 Gr 5A

Figura 15- Micrografias óticas e curvas de microdurezas do aço AISI 316L carbonitretado a diferentes temperaturas

Figura 16- Micrografias óticas e microdurezas do aço super duplex ASTM A890 Gr 5A Carbonitretado

Figura 17- Micrografias óticas e curvas de microdurezas do aço AISI 409 Carbonitretado a diferentes temperaturas 
Figura 18- Varredura em linha do aço AISI $316 \mathrm{~L}$ nitretado a $500^{\circ} \mathrm{C}$

Figura 19- Varredura em linha do aço AISI $316 \mathrm{~L}$ nitretado a $450^{\circ} \mathrm{C}$

Figura 20- Varredura em linha do aço AISI $316 \mathrm{~L}$ nitretado a $400^{\circ} \mathrm{C}$

70

Figura 21- Varredura em linha do aço AISI 409 nitretado a $500^{\circ} \mathrm{C}$

Figura 22- Varredura em linha do aço super duplex ASTM A890 Gr 5A nitretado a $500^{\circ} \mathrm{C}$

Figura 23- Varredura em linha do aço super duplex ASTM A890 Gr 5A nitretado a $450^{\circ} \mathrm{C}$

Figura 24- Varredura em linha do aço super duplex ASTM A890 Gr 5A carbonitretado a $500^{\circ} \mathrm{C}$

Figura 25(a)- Perda de massa em função da distância percorrida

Figura 25(b)- Calota obtida na amostra AISI $316 \mathrm{~L}$ nit. $500^{\circ} \mathrm{C} / 20 \mathrm{~min}$

Figura 26(a)- Perda de massa em função da distância percorrida

Figura 26(b)- Calota obtida na amostra AISI 409 nit. $500^{\circ} \mathrm{C} / 20 \mathrm{~min}$

Figura 27(a)- Perda de massa em função da distância percorrida

Figura 27(b)- Calota obtida na amostra super duplex ASTM A890 Gr $5 \mathrm{~A}$ nit. $500^{\circ} \mathrm{C} / 20 \mathrm{~min}$

Figura 28(a)- Perda de massa em função da distância percorrida 78

Figura 28 (b)- Calota obtida na amostra AISI $316 \mathrm{~L}$ carb. $500^{\circ} \mathrm{C} / 20 \mathrm{~min}$ 78

Figura 29(a)- Perda de massa em função da distância percorrida 79

Figura 29(b)- Calota obtida na amostra AISI 409 carb. $500^{\circ} \mathrm{C} / 20 \mathrm{~min}$

Figura 30(a)- Perda de massa em função da distância percorrida

Figura 30(b)- Calota obtida na amostra super duplex ASTM A890 Gr 5A carb. $500^{\circ} \mathrm{C} / 20 \mathrm{~min} 500^{\circ} \mathrm{C}$

Figura 31- Esquema da obtenção da calota no ensaio de desgaste Microabrasivo

Figura 32- Análise de difração de raios $X$ das amostras do aço AISI 316L (a) substrato; (b) Nit. $400^{\circ} \mathrm{C}$, (c) Nit. $450^{\circ} \mathrm{C}$ e (d) Nit. $500^{\circ} \mathrm{C}$ durante 5 horas

Figura 33- Análise de difração de raios $X$ das amostras do aço super duplex: ASTM A890 Gr $5 A$ (a) substrato; (b) Nit. $400^{\circ} \mathrm{C}$, (c) Nit. $450^{\circ} \mathrm{C}$ e (d) Nit. $500^{\circ} \mathrm{C}$ durante 5 horas 
Figura 34- Análise de difração de raios $X$ das amostras do aço AISI 409:

(a) substrato; (b) Nit. $400^{\circ} \mathrm{C}$, (c) Nit. $450^{\circ} \mathrm{C}$ e (d) Nit. $500^{\circ} \mathrm{C}$ durante 5 horas

Figura 35- Análise de difração de raios $X$ das amostras do aço AISI 304 nitretado por plasma nas temperaturas de 350,380 e $410^{\circ} \mathrm{C}$ durante 5 horas

Figura 36- Análise de difração de raios $X$ das amostras do aço AISI 316L:

(a) substrato; (b) Carb. $400^{\circ} \mathrm{C}$, (c) Carb. $450^{\circ} \mathrm{C}$ e

(d) Carb. $500^{\circ} \mathrm{C}$ durante 10 horas

Figura 37- Análise de difração de raios $X$ das amostras do aço AISI 409

(a) substrato; (b) Carb. $400^{\circ} \mathrm{C}$, (c) Carb. $450^{\circ} \mathrm{C} \mathrm{e}$

(d) Carb. $500^{\circ} \mathrm{C}$ durante 10 horas

Figura 38- Análise de difração de raios $X$ das amostras do aço super duplex: ASTM A890 Gr $5 \mathrm{~A} \mathrm{(a)} \mathrm{substrato;} \mathrm{(b)} \mathrm{Carb.} 400^{\circ} \mathrm{C}$, (c) Carb. $450^{\circ} \mathrm{C}$ e (d) Carb. $500^{\circ} \mathrm{C}$ durante 10 horas

Figura 39- Curvas de polarização anódicas potenciodinâmicas do aço inoxidável super duplex ASTM A890 Gr 5A solubilizado e nitretado por plasma nas temperaturas de $400^{\circ} \mathrm{C} 450^{\circ} \mathrm{C}$ e $500^{\circ} \mathrm{C}$, obtidas em solução de cloreto $3,5 \%$ a temperatura ambiente e $\mathrm{pH}$ igual a 7

Figura 40- Curvas de polarização anódicas potenciodinâmicas do aço inoxidável AISI 409 solubilizado e nitretado por plasma nas temperaturas de $400^{\circ} \mathrm{C}, 450^{\circ} \mathrm{C}$ e $500^{\circ} \mathrm{C}$, obtidas em solução de cloreto $3,5 \%$ a temperatura ambiente e $\mathrm{pH}$ igual a 7

Figura 41- Curvas de polarização anódicas potenciodinâmicas do aço inoxidável AISI 316L solubilizado e nitretado por plasma nas temperaturas de $400^{\circ} \mathrm{C}, 450^{\circ} \mathrm{C}$ e $500^{\circ} \mathrm{C}$, obtidas em solução de cloreto $3,5 \%$ a temperatura ambiente e $\mathrm{pH}$ igual a 7

Figura 42- Curvas de polarização anódicas potenciodinâmicas do aço inoxidável AISI 409 solubilizado e carbonitretado por plasma nas temperaturas de $400^{\circ} \mathrm{C}, 450^{\circ} \mathrm{C}$ e $500^{\circ} \mathrm{C}$, obtidas em solução de cloreto $3,5 \%$ a temperatura ambiente e pHigual a 7

Figura 43- Curvas de polarização anódicas potenciodinâmicas do aço inoxidável AISI 316L solubilizado e carbonitretado por plasma nas temperaturas de $400^{\circ} \mathrm{C} 450^{\circ} \mathrm{C}$ e $500^{\circ} \mathrm{C}$, obtidas em solução de cloreto $3,5 \%$ a temperatura ambiente e pHigual a 7

Figura 44- Curvas de polarização anódicas potenciodinâmicas do aço inoxidável super duplex ASTM A890 Gr 5A solubilizado e carbonitretado por plasma nas temperaturas de $400^{\circ} \mathrm{C}$ e $500^{\circ} \mathrm{C}$, obtidas em solução de cloreto $3,5 \%$ a temperatura ambiente e pHigual a 7 


\section{LISTA DE TABELAS}

Tabela 01- Fases presentes no sistema Fe-N e solubilidade máxima do nitrogênio a $500^{\circ} \mathrm{C}$

Tabela 02- Coeficiente de difusão do nitrogênio nas diversas fases

Tabela 03- Composição química em porcentagem peso das ligas

Tabela 04- Condições de tratamentos para nitretação por plasma

Tabela 05- Condições de tratamentos para carbonitretação por plasma

Tabela 06- Medidas dos valores de microdurezas para os materiais ensaiados 66

Tabela 07- Medidas das profundidades das calotas obtidas por meio dos ensaios de desgaste nas camadas e nos substratos

Tabela 08 - Medidas da densidade de corrente de corrosão e de formação de pites potencial de corrosão e do potencial de pite dos aços inoxidáveis austenítico AISI 316L, ferrítico AISI 409 e super duplex ASTM A890 Gr 5A 


\section{LISTA DE ABREVIATURAS, SIGLAS E SIMBOLOS.}

\begin{tabular}{|c|c|}
\hline AISI & American Iron and Steel Institute \\
\hline$\gamma_{N}$ & Austenita expandida ou Fase "S" \\
\hline$\mu \mathrm{m}$ & Micrometro \\
\hline PREN & Pitting Resistance Equivalent Number \\
\hline $\operatorname{Ccc}$ & cúbico de corpo centrado \\
\hline Cfc & cúbica de face centrada \\
\hline$\gamma$ & Austenita \\
\hline$\alpha$ & Ferrita \\
\hline SDSS & Aço Inoxidável Super Duplex \\
\hline SCC & Corrosão sob Tensão Fraturante \\
\hline$\varepsilon-\mathrm{Fe}_{2 \cdot 3} \mathrm{~N}$ & Nitreto Épsilon \\
\hline$\gamma^{\prime}-\mathrm{Fe}_{4} \mathrm{~N}$ & Nitreto Gama Linha \\
\hline $\mathrm{Cr}_{2} \mathrm{~N}, \mathrm{CrN}$ & Nitretos de Cromo \\
\hline $\mathrm{D}_{\alpha}$ & Coeficiente de Difusão do Nitrogênio na ferrita $\left(\mathrm{cm}^{2} / \mathrm{s}\right)$ \\
\hline $\mathrm{D}_{\gamma}$ & Coeficiente de Difusão do Nitrogênio na Austenita $\left(\mathrm{cm}^{2} / \mathrm{s}\right)$ \\
\hline$D_{\gamma^{\prime}}$ & Coeficiente de Difusão do Nitrogênio no Nitreto Gama Linha $\left(\mathrm{cm}^{2} / \mathrm{s}\right)$ \\
\hline$D_{\varepsilon}$ & Coeficiente de Difusão do Nitrogênio no Nitreto Épsilon $\left(\mathrm{cm}^{2} / \mathrm{s}\right)$ \\
\hline $\mathrm{Ph}$ & Potencial de Hidrogênio lonte \\
\hline $\mathrm{E}$ & Potencial \\
\hline I & Densidade de Corrente \\
\hline$I_{\text {corr }}$ & Densidade de Corrosão \\
\hline$E_{\text {corr }}$ & Potencial de Corrosão \\
\hline$E_{p p}$ & Potencial de Proteção \\
\hline$I_{\text {pass }}$ & Densidade de Corrente Passiva \\
\hline $\mathrm{EO}_{2}$ & Potencial de Evolução de Oxigênio \\
\hline$E_{t}$ & Potencial Transpassivo \\
\hline$E_{\text {pite }}$ & Potencial de Formação de Pites \\
\hline R & Raio da Esfera \\
\hline$\kappa$ & Coeficiente de Desgaste $\left(\mathrm{Nm}^{-1}\right)$ \\
\hline S & Distância Percorrida \\
\hline $\mathrm{N}$ & Força Normal \\
\hline $\mathrm{h}$ & Profundidade da Calota \\
\hline$V_{t}$ & Volume de Desgaste total \\
\hline$V_{s}$ & Volume de desgaste do Substrato \\
\hline$V_{c}$ & Volume de desgaste da Camada \\
\hline$\kappa_{\mathrm{s}}$ & Coeficiente de Desgaste do Substrato \\
\hline$\kappa_{\mathrm{c}}$ & Coeficiente de Desgaste da Camada \\
\hline t & Espessura da camada \\
\hline a & Diấmetro Interno da Camada \\
\hline b & Diâmetro Externo da Camada \\
\hline EDX & Espectroscopia por Difração de Raios X \\
\hline
\end{tabular}




\section{RESUMO}

Oliveira, Antonio Maia de (2004). Nitretação e Carbonitretação por Plasma em Aços Inoxidáveis e suas Influências nas Resistências à Corrosão e ao

Desgaste. São Carlos 2004. 131p. Tese (Doutorado) - Escola de Engenharia de São Carlos, Universidade de São Paulo,

Visando-se determinar as temperaturas mais adequadas de nitretação e carbonitretação por plasma dos aços inoxidáveis austenítico AISI 316L, ferrítico AISI 409 e super duplex ASTM A890 Gr 5A e suas influências nas resistências ao desgaste e à corrosão, amostras desses aços foram tratadas a 400,450 e $500^{\circ} \mathrm{C}$, e submetidas a ensaios micrográficos, de raios $X$, ensaios microabrasivos e de corrosão.

Todas as temperaturas de tratamentos utilizadas nos vários aços estudados produziram camadas com grande regularidade, que tiveram suas espessuras e durezas aumentadas com o aumento da temperatura de tratamento.

Em todos os casos, ocorreu um grande aumento nas resistências ao desgaste microabrasivo das amostras nitretadas ou carbonitretadas, em comparação com o substrato, comprovando a efetividade da fase " $S$ ", produzida nas temperaturas mais baixas, no aumento das durezas e resistências ao desgaste. No caso das amostras tratadas em temperaturas mais elevadas, o nitreto de cromo foi o responsável principal pelo aumento dessa resistência.

Verificou-se por meio dos resultados das curvas de polarização anódicas das camadas nitretadas e carbonitretadas a $400^{\circ} \mathrm{C}$ que, para os três tipos de aços em estudo, tais camadas apresentaram comportamentos semelhantes e superiores aos dos substratos, devido a formação de austenita ou ferrita expandidas. No caso das temperaturas de tratamentos de 450 e $500^{\circ} \mathrm{C}$, as amostras carbonitretadas apresentaram desempenho superior ao das nitretadas e, próximos aos dos substratos, não tendo ocorrido degradação dessa propriedade.

Os tratamentos de nitretação e carbonitretação por plasma, realizados nas temperaturas adequadas definidas no presente trabalho para os principais tipos de aços inoxidáveis, produziram camadas com elevadas durezas e resistências ao desgaste, sem perdas nas características de corrosão, que inclusive melhoraram em alguns casos, permitem a ampliação do uso dos aços inoxidáveis para situações que requeiram aquelas propriedades. 


\section{SUMMARY}

Oliveira de, Antonio Maia (2004). Plasma Nitriding and Carbonitriding in stainless steels and their Influences in the Corrosion and Wear Resistances. São Carlos 2004. 126p. thesis (Doctorate) - School of Engineering of São Carlos, University of São Paulo,

Aiming to determine the most appropriate temperatures of plasma nitriding and carbonitriding of the AISI 316L austenitic stainless steel, AISI 409 ferritic stainless steel and ASTM A890 Gr5A super duplex steel and their influences in the corrosion and wear resistances of those steel samples, they were treated at 400 , 450 and $500^{\circ} \mathrm{C}$, and submitted to micrography analyses, X-ray diffraction, microabrasive wear and corrosion tests.

All treatment temperatures used in the several studied steels produced layers with great regularity, which increased their thickness and hardness with the increase of the treatment temperature.

In all the cases, a great increase occurred in the micro-abrasive wear resistance of the nitrided and carbonitrided samples, in comparison with the substrate, proving the effectiveness of the "S" phase, produced in the lowest temperatures, in the increase of the hardness and wear resistances. In the case of the samples treated at higher temperatures, the chromium nitride was the main responsible one for the increase in the wear resistance.

It was verified through the results of the potenciodinâmicos corrosion tests of the nitrided and carbonitrided layers at $400^{\circ} \mathrm{C}$, that for the three types of steels in the study, such layers presented similar and superior behaviors to that of the substrate, due to austenite or expanded ferrite formation. In the case of the treatment temperatures of 450 and $500^{\circ} \mathrm{C}$, the carbonitrided samples presented superior performance to the nitrided one and similar performance to the substrates samples, without the occurrence of any degradation of that property.

The plasma nitriding and plasma carbonitriding treatments, carried out in the temperatures defined in the present work, for the principal types of stainless steels, to produce layers with high hardness and wear resistances, without losses in the corrosion characteristics, which even got better in some cases, allow to expand the use of the stainless steels in situations where those properties are required. 
1 - INTRODUÇÃo

O rápido progresso da ciência e da tecnologia requer desenvolvimentos constantes de novos materiais e na engenharia de superfícies. A produção de superfícies endurecidas em componentes, para obtenção de melhor resistência à fadiga, ao desgaste e à corrosão, constitui-se num persistente desafio tecnológico.

O impulso para o desenvolvimento da engenharia de superfícies no início da década de 80 deveu-se à disponibilidade comercial de várias tecnologias de superfícies, tais como laser, feixes eletrônicos, técnicas termoquímicas por plasma e implantação iônica. A adoção destas novas tecnologias pela indústria manufatureira, juntamente com as inovações constantes em engenharia de superfícies, permitiu a prática de tratamentos térmicos modernos, de caráter não poluente e baixo custo do processo. Dentre estes tratamentos, destacaram-se a nitretação e a carbonitretação por plasma, pela efetividade, bem como pelo custo relativamente baixo e características não poluentes.

Um dos principais tratamentos utilizados industrialmente para aumentar a resistência ao desgaste e/ou corrosão consiste na eletrodeposição de cromo. No entanto, devido às crescentes restrições em termos de danos ambientais, tal processo tem sofrido obstáculos crescentes à sua utilização, uma vez que o cromo hexavalente, presente na solução de tratamento, é cancerígeno e altamente poluente. Tal fato abre um vasto campo de pesquisa de processos alternativos para 
a obtenção de camadas superficiais que ofereçam características adequadas a aplicações específicas, principalmente quanto ao desgaste e à corrosão.

Os processos termoquimicos de nitretação e carbonitretação por plasma são as técnicas de engenharia de superfície mais promissoras para aumentar a dureza superficial e resistência ao desgaste dos aços inoxidáveis austeníticos, sem deteriorar sua resistência à corrosão. A nitretação ou carbonitretação convencional, líquida ou gasosa, desses aços é normalmente realizada em temperaturas superiores a $500^{\circ} \mathrm{C}$. Neste caso, a formação de nitretos de cromo é inevitável, o que apesar de produzir endurecimento da camada nitretada ou carbonitretada, leva a um esgotamento do teor de cromo no substrato austenitico, assim reduzindo significativamente a resistência à corrosão da camada nitretada, Edenhofer (1974); Sun et al. (1999); Zhu et al. (2000) e Li (2001). A nitretação por plasma dos aços inoxidáveis, que pode ser realizada em temperaturas mais baixas, não apresenta esse inconveniente, consistindo num grande incentivo comercial para as indústrias, reduzindo os custos da produção, produzindo menor distorção e promovendo a obtenção de uma camada superficial dura e resistente ao desgaste sem perda da resistência à corrosão do material, Edenhofer (1976); Fewell et al. (2000-(a)).

Aços com teores de cromo, solubilizado na matriz, superiores a $11 \%$ têm a capacidade de formar película superficial aderente, não porosa e auto-regenerativa, chamada de película passiva; tal película protege o aço da ação de agentes corrosivos (atmosfera, meios aquosos ou orgânicos), e confere a resistência à corrosão daí, a denominação de inoxidável. Além disso, a adição de outros elementos de liga (como Mo, Ni e N) aumenta ainda mais a resistência à corrosão, Sedriks (1996).

Alguns elementos, como $\mathrm{Cr}$, Si e Mo, têm a capacidade de atuar como estabilizadores da fase ferrita (de estrutura cristalina cúbica de corpo centrado); outros, como $\mathrm{Ni}, \mathrm{Mn}, \mathrm{Cu}, \mathrm{C}$ e N, são estabilizadores da austenita (de estrutura 
cristalina cúbica de faces centradas). A introdução de elementos com o intuito de aumentar a resistência à corrosão leva a estabilização de uma ou outra fase, resultando em diferentes comportamentos mecânicos, Solomon e Devine (1982).

Além da resistência à corrosão, esses aços apresentam, dependendo do tipo, outras características importantes, como por exemplo, excelente conformabilidade, alta tenacidade à temperatura ambiente e criogênica, boa resistência à descamação, excelente resistência à oxidação e fluência a altas temperaturas. O cromo é o elemento de liga que confere a resistência à corrosão aos aços inoxidáveis sendo que outros elementos podem ser adicionados para estabilizar outras fases e aumentar a resistência à corrosão ou melhorar as propriedades mecânicas.

Os aços inoxidáveis austeníticos, ferriticos e duplex não podem ser endurecidos por meio de tratamentos térmicos e assim, elementos de ligas e tratamentos termomecânicos são utilizados para minimizar a formação de fases prejudiciais à resistência à corrosão ou tenacidade. Nos aços inoxidáveis austeníticos, a resistência mecânica pode também ser elevada por trabalho a frio, 0 que pode ainda causar a formação de martensita induzida pela deformação. Os aços inoxidáveis martensíticos podem ser tratados termicamente por têmpera e revenido para aumentar a dureza e a resistência mecânica.

Devido à sua resistência à corrosão os aços inoxidáveis são largamente utilizados nas mais diversas aplicações, tais como: indústrias químicas, de alimentos, petroquímicas, de geração de energia, automobilística, dentre outras. Para um número considerável de aplicações, suas características de desgaste e de dureza são relativamente baixas, o que torna necessário em muitas delas, o reforço da superfície por meio de tratamentos de endurecimento superficial do material. Dentre as possibilidades de endurecimento superficial dos aços inoxidáveis, a 
nitretação, a carbonitretação e a cementação por plasma são as técnicas mais promissoras e utilizadas Óbrien e Goodman (1991).

Os aços inoxidáveis apresentam uma ampla aplicabilidade industrial, principalmente em condições severas de resistências à corrosão e, os tratamentos de nitretação e carbonitretação por plasma, apresentam uso crescente, devido às camadas obtidas apresentarem tanto excelente resistência à corrosão quanto ao desgaste, o que justifica a escolha dos mesmos para este trabalho.

As determinações das variáveis adequadas de tratamentos de nitretação e carbonitretação por plasma (tais como, temperatura, pressão e composição da mistura gasosa), são fundamentais para a obtenção de camadas "otimizadas" sem o comprometimento da resistência à corrosão e ao desgaste dos aços inoxidáveis. No caso desses aços nitretados, ocorre na atualidade um grande esforço no sentido de caracterizar adequadamente as camadas e fases produzidas e, no caso da carbonitretação, praticamente inexistem trabalhos nesse sentido. Com o intuito de se avaliar a influência dos tratamentos de nitretação e carbonitretação por plasma sobre os principais tipos de aços inoxidáveis, quanto a estas características, no presente trabalho, foram produzidas e caracterizadas camadas nitretadas e carbonitretadas por plasma nos aços inoxidáveis austenítico AISI 316L, ferrítico AISI 409 e super duplex ASTM A890 Gr 5A. 


\section{2 - REVISÃO BIBLIOGRÁFICA}

\section{1 - AÇOS INOXIDÁVEIS}

Os aços inoxidáveis são ligas resistentes à corrosão e, apresentam um teor mínimo de cromo de $11 \%$, necessário para conferir ao mesmo tal propriedade. Outros elementos de ligas também elevam a resistência à corrosão, como o $\mathrm{Cu}, \mathrm{Al}$, $\mathrm{Si}$, Mo e, particularmente o $\mathrm{Ni}$, que é um dos principais elementos de liga dos aços inoxidáveis austeníticos.

Os aços inoxidáveis são classificados em quatro grupos de acordo com a microestrutura básica e com a possibilidade de endurecimento por tratamentos térmicos, que são:
a) Aços inoxidáveis austeníticos;
b) Aços inoxidáveis ferriticos;
c) Aços inoxidáveis duplex;
d) Aços inoxidáveis martensíticos. 


\subsection{1 - Aços Inoxidáveis Austeníticos}

Os aços inoxidáveis austeníticos constituem a família mais importante dos aços inoxidáveis em termos de número de tipos e aplicações. Estes aços apresentam excelente resistência à corrosão e à oxidação devido à formação de uma fina camada superficial de óxido, porém, suas características de desgaste e de dureza são relativamente baixas, Davis (1994); Padilha (1994). Contudo, muitos trabalhos têm demonstrado que os tratamentos superficiais de nitretação e carbonitretação por plasma em temperatura relativamente baixa (abaixo de $500^{\circ} \mathrm{C}$ ) resultam na produção de uma camada superficial, responsável pelo aumento da dureza e resistência ao desgaste sem diminuição da resistência à corrosão, que pode inclusive ser aumentada. Esta camada, denominada de fase "S" ou austenita expandida, constitui-se numa fase termodinamicamente metaestável com uma supersaturação de nitrogênio que permanece em solução sólida resultando numa estrutura cúbica de face centrada distorcida Blawert et al. (1996); Menthe and Rie (1999); Menthe et al. (2000); Zhu et al. (2000); Bell (2002); Dearnley (2002).

Nos anos 80 , Zhang e Bell (1985) foram os primeiros pesquisadores a estudarem a nitretação por plasma em baixa temperatura, que também foi estudada independentemente por Ichii et al. (1986). Por meio de suas investigações, eles descobriram que a nitretação por plasma dos aços inoxidáveis austeníticos AISI 304 e 316 a temperaturas próximas a $400^{\circ} \mathrm{C}$, resultaram na obtenção de uma camada nitretada com até $20 \mu \mathrm{m}$ de espessura, a qual apresentou alta dureza e excelente resistência ao desgaste, bem como boa resistência à corrosão, uma vez que baixas temperaturas de tratamento impedem a formação de nitretos de cromo, o que deterioraria as propriedades de corrosão. O grande aumento na dureza e conseqüentemente na resistência ao desgaste é devido à supersaturação de 
nitrogênio e/ou carbono na camada nitretada ou carbonitretada, que produz uma elevada densidade de discordâncias e tensões compressivas, que podem adicionalmente aumentar a resistência à fadiga de peças submetidas a esses tratamentos. A resistência à corrosão pode ser mantida ou até aumentada por esses tratamentos, principalmente a corrosão por pites em meios à base de cloretos, devido ao elevado aumento no PREN (Pitting Resistance Equivalent Number), ocasionado pelo nitrogênio, que é o elemento químico existente mais efetivo quanto a esse efeito, dado pela relação; $(\operatorname{PREN}=(\% \mathrm{Cr})+3,3(\% \mathrm{Mo})+$ $16(\% M)$. O teor atômico de nitrogênio no substrato austenítico é no máximo $8,7 \%$, enquanto que na austenita expandida varia de 20 a $45 \%$. Grandes esforços têm sido feitos para investigar o fenômeno da nitretação por plasma a baixa temperatura dos aços inoxidáveis austeníticos, objetivando um melhor entendimento da estrutura nitretada e a otimização do processo para produção de camadas de alta qualidade, Zhu et al. (2000) e Bell (2002).

\subsection{2 - Aços Inoxidáveis Ferríticos.}

Os aços inoxidáveis ferríticos, que contêm de 11 a $29 \%$ de $\mathrm{Cr}$ e outros elementos de liga em teor variável, possuem estrutura cúbica de corpo centrado (CCC) e são magnéticos a temperatura ambiente. As ligas ferríticas com $11 \%$ de $\mathrm{Cr}$ possuem menor resistência à corrosão, baixo custo e grande aplicação em sistemas de exaustão da indústria automobilística, reservatórios e outras aplicações funcionais. As ligas $\mathrm{Fe}-\mathrm{Cr}$ nesta faixa são totalmente ferríticas até a sua fusão e, portanto, são não alotrópicas e não endurecem por meio de tratamentos térmicos. Sua microestrutura pode consistir de ferrita, fase sigma e carbonetos $M_{23} C_{6}$, (onde 
"M" indica metal), e outras fases também podem se formar devido à exposição a altas temperaturas. A fase sigma, que é uma fase intermetálica, aumenta a dureza, mas, por outro lado, diminui a ductilidade, tenacidade ao entalhe e resistência à corrosão. A fase sigma é dissolvida a temperaturas acima de $900^{\circ} \mathrm{C}$, Aksoy et al. (1997); Aksoy et al. (2001).

Os aços inoxidáveis ferríticos não são usados em condições requerendo resistência ao desgaste devido a sua baixa dureza. Porém, materiais resistentes ao desgaste podem ser obtidos ou pelo reforço das fases moles com fases mais duras ou por meio de processos de endurecimentos superficiais. Dentre esses processos de endurecimento superficial, destaca-se a nitretação por plasma, pela sua efetividade, bem como pelo seu custo relativamente baixo e não poluente.

\subsection{3 - Aços Inoxidáveis Duplex}

Os aços inoxidáveis duplex são ligas a base de $\mathrm{Fe}, \mathrm{Cr}$ e $\mathrm{Ni}$ com uma microestrutura ferrítica-austenítica à temperatura ambiente. Solomon e Devine (1982) definem uma liga duplex como aquela constituída de duas fases microestruturais. As fases estão presentes em frações volumétricas proporcionais e bem definidas, ao contrário da situação onde uma fase está presente como um fino precipitado dentro de uma fase maior. Um aço inoxidável duplex é uma liga onde as duas fases são inoxidáveis, possuindo pelo menos os $12 \%$ de Cr necessários para formar um filme passivo que protege a liga contra a corrosão em muitos meios onde são utilizados, Krainer (1995). As fases inoxidáveis mais comuns são a austenita cúbica de face centrada, denominada de fase gama $(\gamma)$, e a ferrita cúbica de corpo centrado, ou fase alfa ( $\alpha$ ) Bian e Griffiths (1927). 
As composições químicas básicas dos aços inoxidáveis duplex, segundo Pohl (1995), variam entre $21 \%$ e $28 \%$ de $\mathrm{Cr}$ e $5 \%$ a $7 \%$ de $\mathrm{Ni}$. Além do $\mathrm{Cr}$ e $\mathrm{Ni}$, outros elementos de liga como o $\mathrm{N}, \mathrm{Mo}, \mathrm{Cu}, \mathrm{Si}, \mathrm{Mn}$ e $\mathrm{W}$ podem ser adicionados em pequenas quantidades para controlar o equilíbrio estrutural e melhorar a resistência à corrosão, Bian e Griffiths (1927); Pohl (1995). De acordo com Solomon \& Devine (1982), a composição química dos aços inoxidáveis duplex varia entre 17\% e 30\% de $\mathrm{Cr}$ e $3 \%$ a $13 \%$ de $\mathrm{Ni}$, aproximadamente $0,5 \%$ a $2,0 \%$ de $\mathrm{Mn}$ e Si, principalmente para a desoxidação, e outros elementos tais como $\mathrm{Mo}, \mathrm{Cu}, \mathrm{Nb}$ e teores de $\mathrm{C}$ abaixo de $0,08 \%$. Classificam a liga duplex em aço inoxidável duplex (DSS) convencional, com composição química básica de $22 \%$ de $\mathrm{Cr}, 5 \%$ de Ni, $3 \%$ de $\mathrm{Mo}$ e $0,17 \%$ de $\mathrm{N}$, e aço inoxidável superduplex (SDSS) de alta liga com composição química básica de $25 \%$ de $\mathrm{Cr}, 7,5 \%$ de $\mathrm{Ni}, 4,0 \%$ de $\mathrm{Mo}$, e $0,3 \%$ de $\mathrm{N}$, que são utilizados para situações de corrosão por pite e corrosão sob tensão fraturante (SCC) em ambientes contendo cloretos. Os aços inoxidáveis superduplex, segundo Nilsson (1992), contêm quantidades suficientes de $\mathrm{Cr}$, Mo e $\mathrm{N}$ para produzirem um número equivalente de resistência ao pite (PREN) superior a 40. Estes elementos atuam de forma semelhante no aumento da resistência à corrosão por pite, deslocando o potencial de passivação na direção mais nobre, aumentando a região passiva e reduzindo a taxa de corrosão generalizada.

Os aços inoxidáveis duplex apresentam as mais variadas aplicações industriais, principalmente nas indústrias petroquímicas, de gás e óleo, de papel e no controle da poluição industrial, Ku (1997). Esses aços têm substituído com sucesso os aços inoxidáveis austeníticos em aplicações específicas, Reick et al. (1992). 


\section{2 - NITRETAÇÃo E CARBONITRETAÇAO POR PLASMA}

Nas últimas décadas, ocorreu um grande crescimento no número de técnicas associadas à modificação de superfícies. Desde os anos 80 as técnicas de modificação de superfície tais como, a modificação por gás reativo e bombardeamento iônico, a implantação iônica, assim como as deposições de filmes superficiais, têm passado por um significativo avanço, Greene (1994); Grün e Güther (1991). Estas técnicas fazem uso de plasmas, feixes de elétrons, laser e deposição química e física a vapor, substituindo gradativamente as técnicas convencionais como a galvanoplastia, zincagem, pastas metálicas, nitretação líquida, cementação e outras que geram substâncias nocivas ao meio ambiente e/ou baixa eficácia comparada com as técnicas modernas. Dentre os tratamentos por plasma, destacam-se os tratamentos termoquímicos de nitretação e carbonitretação por serem processos facilmente controláveis, repetitivos e que possibilitam a produção de superfícies com propriedades metalúrgicas apropriadas para adaptar-se às várias condições de uso, Jack (1952); Spalvins (1983) e Alves Jr. (1995).

O efeito endurecedor do nitrogênio no ferro e nos aços foi constatado no final do século XIX, porém somente em 1923, Fry descobriu que a fragilidade da camada obtida nas peças nitretadas poderia ser eliminada utilizando-se temperaturas de tratamento relativamente baixas. Desde então, têm-se utilizado, comercialmente, temperaturas abaixo de $450^{\circ} \mathrm{C}$, para a realização dos processos de nitretação e carbonitretação por plasma, Alves Jr. (2000).

A nitretação por plasma foi patenteada por J.J. Egan em 1931 nos Estados Unidos da América e por Berghaus em 1932 na Suiça, porém seu uso comercial iniciou-se, somente, na década de 60 . No passado, a aceitação do mercado à 
utilização industrial da nitretação por plasma ficou restrita pelo alto custo e dificuldades técnicas dos equipamentos. Tais dificuldades consistiam em aberturas de arcos elétricos e superaquecimento de partes dos componentes tratados no reator a plasma. Com o advento da eletrônica de potência e da microeletrônica esses problemas foram minimizados ou quase completamente resolvidos, contribuindo para o grande avanço na utilização desta técnica, especialmente nas indústrias aeroespacial, automobilistica e ferramentaria, visando à melhoria das propriedades metalúrgicas dos componentes.

A nitretação por plasma consiste num processo termoquímico que introduz nitrogênio atômico e permite a formação de nitretos de elementos que compõem o substrato. A relação entre os mecanismos dominantes, os parâmetros do sistema de tratamento e a composição química do substrato permitem a nitretação do material, Blawert et al. (1996); Kuzucu et al. (1998); Aksoy et al. (1999) e Moustafa et al. (2000). A camada produzida consiste de uma camada de compostos, constituída predominantemente das fases $\varepsilon-\left(\mathrm{Fe}_{2-3} \mathrm{~N}\right)$ e/ou $\gamma^{\prime}-\left(\mathrm{Fe}_{4} \mathrm{~N}\right)$, as quais são responsáveis pelas boas propriedades tribológicas e anticorrosivas e uma zona de difusão onde o nitrogênio encontra-se dissolvido intersticialmente ou na forma de nitretos no substrato, levando a uma acentuada resistência à fadiga, Pye (1994).

Não há um modelo padrão que explique os processos de nitretação e carbonitretação por plasma, no entanto, há controvérsias quanto às espécies ativas do plasma, responsáveis pelo processo de nitretação, Rie (1989). Vários modelos foram propostos para explicar a cinética do processo. Tibbets (1974), observando a nitretação de amostras que possuiam em sua superfície, uma grade com potencial repulsivo para os ions positivos, obteve a mesma taxa de nitretação para as amostras nitretadas com ou sem esse potencial, concluindo então, serem neutras as espécies responsáveis pela nitretação por plasma. Outros modelos levam em consideração a transferência de massa de átomos e moléculas ionizadas. Hudis et. 
al. (1973), acreditam que a transferência de massa das espécies $\mathrm{NH}^{+}$e $\mathrm{NH}_{2}^{+}$é predominantemente no mecanismo de nitretação por plasma, embora apenas o ambiente ionizado não seja condição suficiente. É necessário também o bombardeamento da amostra por essas espécies.

Devido à complexidade das espécies presentes no plasma nitretante, de interação entre estas espécies e também destas com a superficie a ser nitretada, foi difícil até o presente, um modelo único de transferência de massa dos elementos intersticiais para a amostra. O processo de nitretação é controlado pela transferência de massa do plasma e interações plasma/superfície. Dentre os vários modelos, segundo, Lampe et al. (1993) o modelo mais amplamente usado pela maioria dos pesquisadores da área é o modelo proposto por KÖLBEL.

Neste modelo, o catodo (peça) é bombardeado por íons de nitrogênio e partículas neutras altamente energéticas, possibilitando a ocorrência de importantes reações, produzindo além do aquecimento e defeitos na rede, arrancamento dos átomos da sua superfície (sputtering). Estes átomos arrancados interagem com espécies reativas do plasma próximas à superfície de peça, formando inicialmente compostos instáveis do tipo $\mathrm{FeN}$, no caso dos aços carbono, que ao serem adsorvidos na superfície das peças, decompõem-se em nitretos mais estáveis com teores mais baixo de nitrogênio, do tipo $\xi-\mathrm{Fe}_{2} \mathrm{~N}, \varepsilon-\mathrm{Fe}_{2-3} \mathrm{~N}$ e $\gamma^{\prime}-\mathrm{Fe}_{4} \mathrm{~N}$, liberando átomos de nitrogênio, que por sua vez, pelo processo de difusão a partir da superfície penetram no interior da peça, esse mecanismo ocorre de acordo com os seguintes passos:

- lonização da mistura gasosa

- Sputtering do ferro pelas espécies ionizadas

- Formação de nitretos de ferro entre os átomos arrancados da superfície e as espécies ativas do plasma 
- Deposição de nitretos de ferro na superfície da amostra, conforme é mostrado na figura 01.

Nesse mecanismo de recombinações, há um excesso de nitrogênio que difundirá para dentro da amostra ou voltará para o plasma. A zona mais interna formada pela difusão do nitrogênio atômico na amostra é chamada de zona de difusão e a mais superficial é a zona de ligação ou de compostos. A zona de difusão é formada por uma solução sólida de nitrogênio no substrato e alguns precipitados dispersos de nitretos de ferro ou dos elementos de liga presentes no aço. A zona de compostos é formada das fases $\gamma^{\prime}-\mathrm{Fe}_{4} \mathrm{~N}$ e $\varepsilon-\mathrm{Fe}_{2 \cdot 3} \mathrm{~N}$ para uma matriz de ferro.

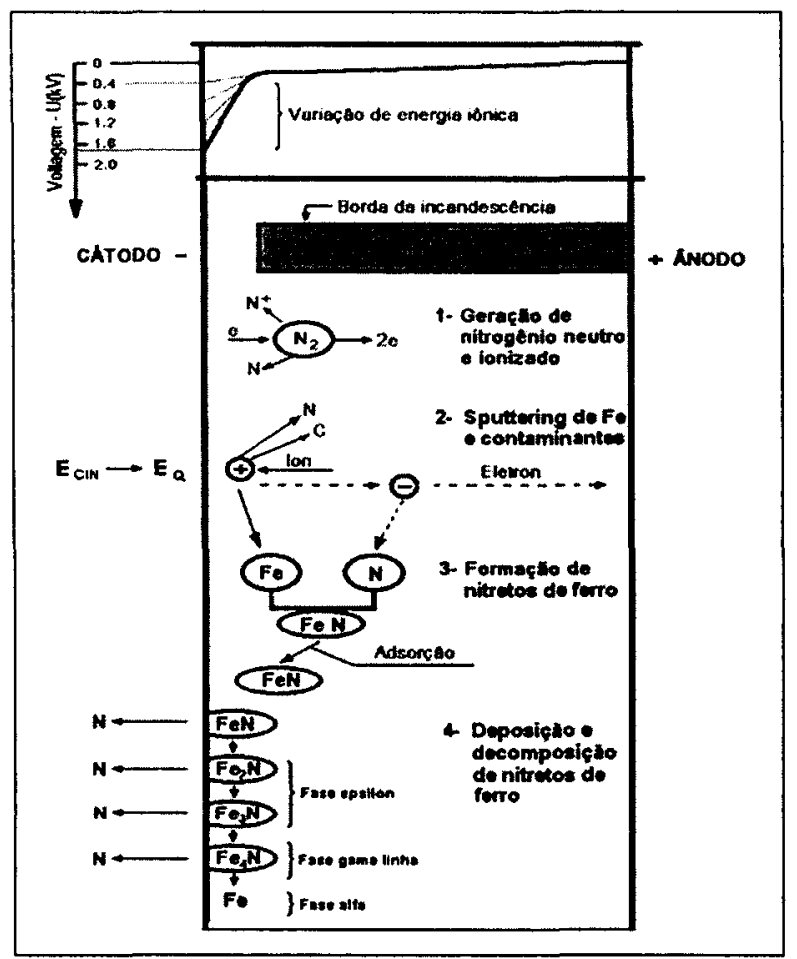

Figura 01 - Reações superficiais que ocorrem durante a nitretação por plasma, modelo de KÖLBEL. 


\subsection{1 - Reações que ocorrem no interior do Plasma}

O processo de nitretação por plasma está associado a vários processos de colisões de átomos e moléculas para geração das espécies ativas do gás nitretante, que são de grande importância no mecanismo de nitretação por plasma. Num meio nitretante (mistura $\mathrm{H}_{2} / \mathrm{N}_{2}$ ), as reações mais freqüentes na luminescência negativa (ou plasma), são aquelas determinadas pelas colisões elétrons-moléculas, podendo ser assim classificadas, Pettijean (1984):

a - lonização - $\mathrm{Na}$ ionização os elétrons mais energéticos, ao colidirem com as moléculas do gás, promovem a remoção de um elétron do átomo, produzindo um íon e dois elétrons de acordo com as reações:

$$
\begin{aligned}
& e^{B}+\mathrm{N}_{2} \rightarrow 2 e^{B}+\mathrm{N}_{2}^{+} \\
& e^{B}+\mathrm{H}_{2} \rightarrow 2 e^{B}+\mathrm{H}_{2}^{+} \\
& e^{\mathrm{B}}+\mathrm{N}_{x} \mathrm{H}_{y} \rightarrow 2 e^{B}+\mathrm{N}_{x} \mathrm{H}_{y}^{+}
\end{aligned}
$$

b - Excitação - A excitação ocorre quando um átomo ou uma molécula qualquer em seu estado estacionário ou num estado já excitado, absorve energia suficiente por meio de uma colisão com uma outra partícula pesada ou com um elétron ou um fóton. Neste caso, se a energia de colisão do elétron for inferior àquela necessária para ionização, ocorrerão as seguintes reações:

$$
\begin{aligned}
& e^{-}+\mathrm{N}_{2} \rightarrow \mathrm{e}^{-}+\mathrm{N}_{2}^{*} \\
& \mathrm{e}^{-}+\mathrm{H}_{2} \rightarrow \mathrm{e}^{-}+\mathrm{H}_{2} \\
& \mathrm{e}^{-}+\mathrm{N}_{\mathrm{x}} \mathrm{H}_{\mathrm{y}} \rightarrow \mathrm{e}^{-}+\mathrm{N}_{\mathrm{x}} \mathrm{H}_{\mathrm{y}}{ }^{*}
\end{aligned}
$$


c - Relaxação ou emissão - É o processo inverso da excitação. A relaxação se dá pelo decaimento dos elétrons para níveis de menor energia, onde a transição do processo é acompanhada pela emissão de fótons. Desta forma, a luminosidade da descarga luminescente se deve à relaxação devida à emissão de energia em forma de luz.

$$
\begin{aligned}
& \mathrm{N}_{2} \rightarrow \mathrm{N}_{2}+h v \\
& \mathrm{H}_{2} \rightarrow \mathrm{H}_{2}+\mathrm{hv} \\
& \mathrm{N}_{x} \mathrm{H}_{\mathrm{y}} \rightarrow \mathrm{N}_{\mathrm{x}} \mathrm{H}_{\mathrm{y}}+\mathrm{hv}
\end{aligned}
$$

d - Recombinação - Ocorre quando espécies ionizadas chocam-se com uma superfície, e elétrons dessa superfície são liberados neutralizando as espécies pelos seguintes processos de recombinação.

$$
\begin{aligned}
& \mathrm{N}_{2}^{+}+\mathrm{e}^{-} \rightarrow \mathrm{N}_{2} \\
& \mathrm{H}_{2}^{+}+\mathrm{e}^{-} \rightarrow \mathrm{H}_{2} \\
& \mathrm{~N}_{\mathrm{x}} \mathrm{H}_{\mathrm{y}}^{+}+\mathrm{e}^{-} \rightarrow \mathrm{N}_{\mathrm{x}} \mathrm{H}_{\mathrm{y}}
\end{aligned}
$$

e - Dissociação - Neste processo ocorre a ruptura isolada de uma molécula. No caso da nitretação, ocorre a ruptura ou dissociação de uma molécula de nitrogênio em dois átomos devido ao impacto desta com um elétron em elevado estado energético, de acordo com as reações:

$$
\begin{aligned}
& e^{-}+N_{2} \rightarrow e^{-}+N+N \\
& e^{-}+N_{2} \rightarrow e^{-}+N^{+}+N \\
& e^{-}+N_{2} \rightarrow e^{-}+N^{+}+N^{*}
\end{aligned}
$$




\subsection{2 - Nitretação e Carbonitretação por Plasma dos Aços Inoxidáveis}

O endurecimento superficial dos aços inoxidáveis é freqüentemente utilizado para melhorar a resistência ao desgaste e ao engripamento. Dentre os métodos utilizados destacam-se os processos mecânicos, térmicos, quimicos, termoquímicos e metalizações. Os tratamentos de nitretação e carbonitretação por plasma são realizados em temperaturas relativamente baixas, proporcionando niveis de dureza acima de $1000 \mathrm{HV}$, relativa estabilidade dimensional, não alterando substancialmente a microestrutura do núcleo da peça e, são por essas razões muito utilizados.

Nos processos realizados em altas temperaturas (por exemplo, acima de $500^{\circ} \mathrm{C}$ ), o nitrogênio proveniente do meio nitretante penetra no aço por difusão, combina-se com elementos de liga, principalmente cromo no caso dos aços inoxidáveis e forma uma camada dura composta de nitretos devido à grande afinidade entre $\circ$ nitrogênio e $\circ$ cromo. $A$ formação desses nitretos causa 0 empobrecimento de cromo em solução sólida, provocando a diminuição da resistência à corrosão dos aços inoxidáveis. Em aços inoxidáveis com alto teor de cromo, as camadas formadas em temperaturas superiores a $500^{\circ} \mathrm{C}$ apresentam freqüentemente problemas de aderência, porosidade e menor resistência à corrosão devido à formação de nitretos de cromo. O desempenho da camada nitretada depende fortemente da sua microestrutura, ou seja, do tipo, quantidade, morfologia, tamanho, relações de orientação e distribuição dos nitretos formados, que por sua vez dependem principalmente da composição do aço e da temperatura do processo de nitretação.

A formação de nitretos em aços inoxidáveis é muito influenciada pelos elementos de ligas tais como cromo e nitrogênio, presentes em até $30 \%$ em peso 
nessas ligas. Nitretos de cromo $\left(\mathrm{Cr}_{2} \mathrm{~N}\right.$ e $\left.\mathrm{CrN}\right)$ são mais estáveis do que os nitretos de ferro $\left(\alpha "-\mathrm{Fe}_{16} \mathrm{~N}_{2} ; \gamma^{\prime}-\mathrm{Fe}_{4} \mathrm{~N} ; \varepsilon-\mathrm{Fe}_{2-3} \mathrm{~N} ; \xi-\mathrm{Fe}_{2} \mathrm{~N}\right)$ e tendem a se formar com maior rapidez. O níquel diminui a solubilidade do nitrogênio na austenita e, embora não se tenha conhecimento da formação de nitretos de niquel durante a nitretação desses aços, ele é solúvel nos nitretos de ferro e tende a se particionar preferencialmente no nitreto $\gamma^{\prime}-\mathrm{Fe}_{4} \mathrm{~N}$ com estrutura CFC. Nos aços austeníticos nitretados ou carbonitretados a temperaturas inferiores a $420^{\circ} \mathrm{C}$, forma-se somente a austenita expandida ou $\gamma_{N}$, com estrutura CFC supersaturada com nitrogênio e parâmetros de rede expandido, com valores equivalentes ao do nitreto de ferro $\gamma^{\prime}-\mathrm{Fe}_{4} \mathrm{~N}$, Sun e $\mathrm{Li}$ (1999).

A fase $\gamma_{N}$ se decompõe com o aumento da temperatura ou do teor de nitrogênio em nitretos de cromo $\left(\mathrm{CrN}\right.$ e $\left.\mathrm{Cr}_{2} \mathrm{~N}\right)$ e de ferro $\left(\gamma^{\prime}\right.$ ou $\varepsilon$ dependendo da relação $\mathrm{Cr} / \mathrm{Ni})$. A velocidade de crescimento da camada é influenciada em maior escala pela decomposição química da fase, e a espessura da camada diminui com o aumento da relação $\mathrm{Cr} / \mathrm{Ni}$, ou seja, o aumento do teor de cromo favorece a precipitação de fases intermetálicas que geralmente reduzem as propriedades desses materiais tais como dutilidade, tenacidade e resistência à corrosão.

\subsection{3 - Fases Presentes nas Camadas Nitretadas e Carbonitretadas}

Os diagramas de equilibrio ou de fases binários ou ternários são ferramentas importantes para o entendimento das fases formadas durante os processos de nitretação e carbonitretação dos aços inoxidáveis.

Na figura 02 é mostrado o diagrama de equilíbrio binário para o sistema Fe$\mathrm{N}$. Na tabela 01 estão apresentadas algumas fases existentes em função da 
solubilidade do nitrogênio, com a ocorrência de três fases intermetálicas que são os nitretos de ferro $\left(\mathrm{Fe}_{4} \mathrm{~N}\left(\gamma^{\prime}\right), \mathrm{Fe}_{2 \cdot 3} \mathrm{~N}(\varepsilon)\right.$ e $\left.\mathrm{Fe}_{2} \mathrm{~N}(\xi)\right)$, além das fases ferrita e austenita. Verifica-se também que aparecem duas reações eutetóides.

O nitreto de ferro $\mathrm{Fe}_{4} \mathrm{~N}\left(\gamma^{\prime}\right)$ é cúbico de faces centradas contendo teoricamente $19,3 \%$ de $\mathrm{N}$ atômico, o nitreto $\mathrm{Fe}_{2-3} \mathrm{~N}(\varepsilon)$ é hexagonal compacto e pode apresentar uma quantidade de nitrogênio muito variável enquanto que o nitreto $\mathrm{Fe}_{2} \mathrm{~N}(\xi)$ contém $33 \%$ de $\mathrm{N}$ atômico e possui estrutura ortorrômbica.

A ferrita ou fase alfa é constituída de uma solução sólida de nitrogênio no ferro com limite máximo de solubilidade de $0,4 \%$ de $\mathrm{N}$ atômico. $\mathrm{A}$ sua estrutura cristalina é cúbica de corpo centrado. A fase gama ou austenita é constituída de uma solução sólida de nitrogênio com uma estrutura cristalina cúbica de face centrada e com limite máximo de solubilidade de $10,3 \%$ de $\mathrm{N}$ atômico.

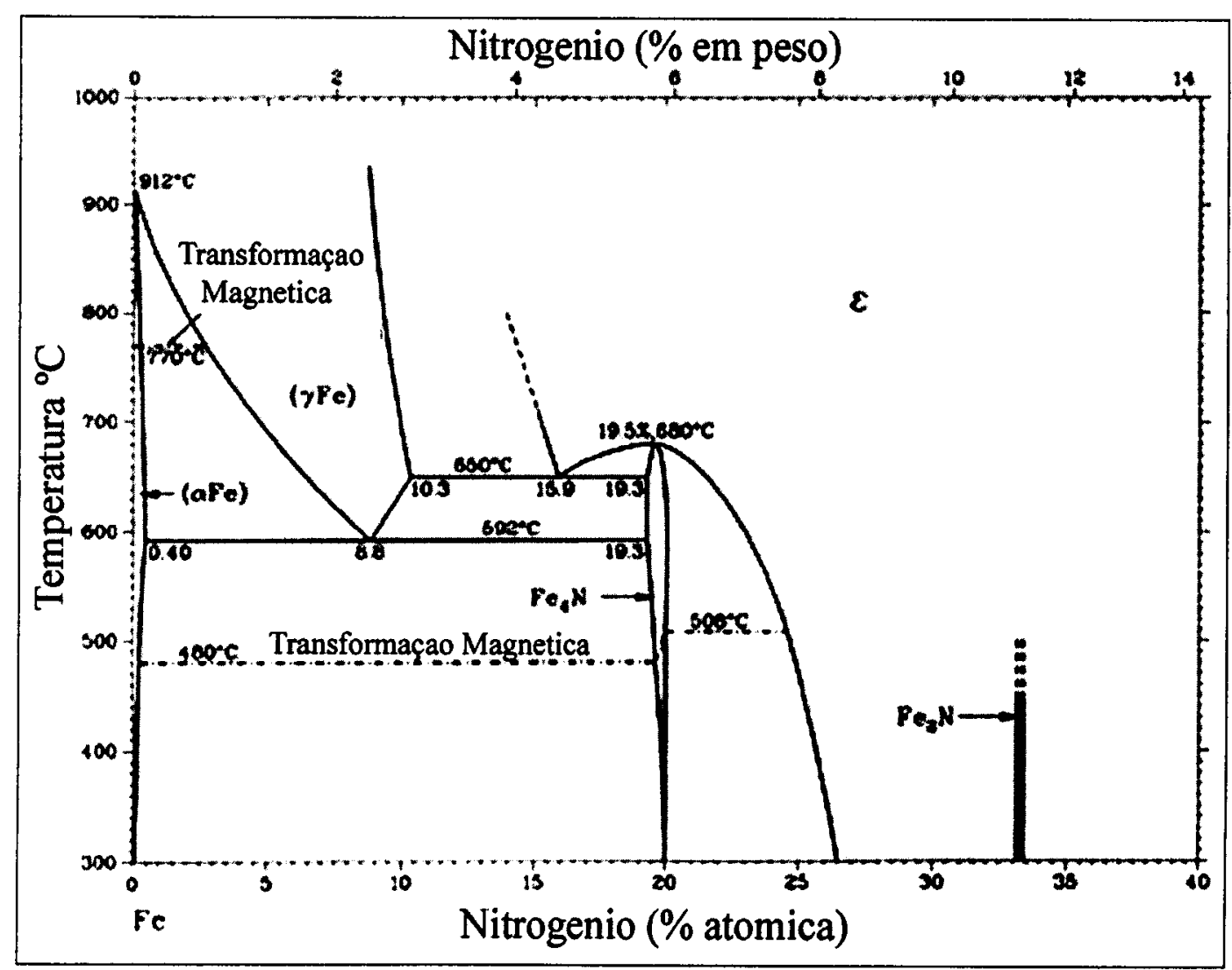

Figura 02 - Diagrama de equilíbrio Fe-N, Hansen (1958). 
A solubilidade do nitrogênio nos aços varia de acordo com a temperatura, e nas temperaturas usadas nos processos industriais de nitretação, a máxima solubilidade em porcentagem atômica na ferrita de alta pureza é de $0,4 \%$. Quando ultrapassado esse valor, inicia-se a formação dos nitretos. O primeiro tipo de nitreto a se formar é o $\mathrm{Fe}_{4} \mathrm{~N}\left(\gamma^{\prime}\right)$ com teor de nitrogênio da ordem de $19,3 \%$, estável até $650^{\circ} \mathrm{C}$, que constitui a camada branca ou camada de compostos. Quando esse teor de nitrogênio em porcentagem atômica atinge $19,5 \%$, formam-se os nitretos $\mathrm{Fe}_{2-3} \mathrm{~N}$ (ع), que podem dissolver até $33 \%$ de $\mathrm{N}$ a temperaturas inferiores a $500^{\circ} \mathrm{C}$.

A presença do carbono intersticial nos processos de carbonitretação favorece a formação do nitreto $\mathrm{Fe}_{2-3} \mathrm{~N}(\varepsilon)$ na camada de compostos. A solubilidade do nitrogênio em porcentagem atômica na austenita é 25 vezes maior que na ferrita (0,4\% de $\mathrm{N}$ atômico), podendo chegar a $10,3 \%$. Quando o cromo está presente em grande quantidade, como no caso dos aços inoxidáveis em estudo, outros tipos de

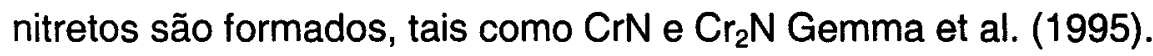

O nitreto de cromo $(\mathrm{CrN})$ apresenta $21,2 \%$ em peso de nitrogênio e estrutura cúbica de faces centradas, enquanto que o nitreto de cromo $\left(\mathrm{Cr}_{2} \mathrm{~N}\right)$ possui $11,8 \%$ em peso de nitrogênio e uma estrutura hexagonal compacta Kliauga (1998).

$\mathrm{Na}$ tabela 01 são apresentadas as fases presentes no sistema binário $\mathrm{Fe}-\mathrm{N}$ e solubilidade máxima para cada fase em equilíbrio. Observa-se também o tipo de estrutura cristalina de cada fase com seus respectivos parâmetros de rede. 
Tabela 01- Fases presentes no sistema Fe-N e solubilidade máxima do nitrogênio a $500^{\circ} \mathrm{C}$ Jack e Jack (1973).

\begin{tabular}{|c|c|c|c|c|c|}
\hline Fase & Formula & $\begin{array}{c}\text { Rede de } \\
\text { Bravais }\end{array}$ & $\begin{array}{c}\text { Parâmetro de } \\
\text { rede }\left(A^{\circ}\right)\end{array}$ & $\mathrm{N}(\%$ at. $)$ & $\mathrm{N}(\%$ peso $)$ \\
\hline Ferrita $(\alpha)$ & $\mathrm{Fe}$ & $\mathrm{ccc}$ & $\mathrm{a}=2,8664$ & 0,4 & 0,1 \\
\hline Austenita $(\gamma)$ & $\mathrm{Fe}$ & $\mathrm{cfc}$ & $\mathrm{a}=3,572$ & 11 & 2,8 \\
\hline$\alpha^{\prime \prime}$ & $\mathrm{Fe}_{16} \mathrm{~N}_{2}$ & Tetragonal & $\begin{array}{c}\mathrm{a}=5,72, \\
\mathrm{c} / \mathrm{a}=1,10\end{array}$ & 11,1 & 2,8 \\
\hline$\gamma^{\prime}$ & $\mathrm{Fe}_{4} \mathrm{~N}$ & $\mathrm{cfc}$ & $\mathrm{a}=3,795$ & 20 & $5,77-5,88$ \\
\hline$\varepsilon$ & $\mathrm{Fe}_{2 \cdot 3} \mathrm{~N}$ & $\mathrm{hc}$ & $\begin{array}{c}\mathrm{a}=2,764 \\
\mathrm{c} / \mathrm{a}=1,599\end{array}$ & $18 \mathrm{a} 32$ & $7,5-11$ \\
\hline$\xi$ & $\mathrm{Fe}_{2} \mathrm{~N}$ & Ortorrômbica & $\begin{array}{c}\mathrm{a}=5,530 \\
\mathrm{~b}=4,480 \\
\mathrm{c}=4,425\end{array}$ & 33,3 & 11,14 \\
\hline
\end{tabular}

\subsection{4 - Difusão do Nitrogênio na Austenita, Ferrita e na Camada de Compostos}

O crescimento da camada nitretada apresenta um comportamento parabólico com o tempo de nitretação uma vez que o processo é controlado por difusão. Com a formação da camada de compostos, o coeficiente de difusão varia durante o processo de nitretação. Este comportamento deve-se ao fato de que 0 coeficiente de difusão do nitrogênio e do carbono na camada de compostos é menor do que na ferrita e na austenita. Deve-se esperar um comportamento ainda mais atípico nos aços inoxidáveis duplex, pois além da camada de compostos, esses aços apresentam duas estruturas estáveis à temperatura de nitretação (austenita e ferrita), cujos coeficientes de difusão dos intersticiais nitrogênio e carbono também são diferentes nestas duas estruturas.

A tabela 02 mostra os valores dos coeficientes de difusão do nitrogênio nas diversas fases à temperatura de $530^{\circ} \mathrm{C}$, Rozendaal et al (1983); Mittermeijer e Somers (1995); Torchane et al. (1996) e Sun e Bell (1997). 
Tabela 02 - Coeficientes de difusão do nitrogênio nas diversas fases a $530^{\circ} \mathrm{C}$.

\begin{tabular}{|l|l|}
\hline $\mathrm{D}_{\alpha}\left(\mathrm{cm}^{2} / \mathrm{s}\right)$ & $5,697 \times 10^{-8}$ \\
\hline $\mathrm{D}_{\gamma}\left(\mathrm{cm}^{2} / \mathrm{s}\right)$ & $1,056 \times 10^{-17}$ \\
\hline $\mathrm{D}_{\gamma^{\prime \prime}}\left(\mathrm{cm}^{2} / \mathrm{s}\right)$ & $1,158 \times 10^{-9}$ \\
\hline $\mathrm{D}_{\varepsilon}\left(\mathrm{cm}^{2} / \mathrm{s}\right)$ & $1,75 \times 10^{-10}$ \\
\hline
\end{tabular}

Onde:

$D_{\alpha}=$ Coeficiente de difusão do nitrogênio na ferrita;

$D_{\gamma}=$ Coeficiente de difusão do nitrogênio na austenita;

$D_{\gamma^{\prime}}=$ Coeficiente de difusão do nitrogênio no nitreto $\gamma^{\prime}$;

$D_{\varepsilon}=$ Coeficiente de difusão do nitrogênio no nitreto $\varepsilon$.

\subsection{5 - Vantagens e Limitações da Nitretação e Carbonitretação por Plasma}

O processo de nitretação por plasma oferece várias vantagens sobre os processos convencionais e outros tratamentos superficiais. Algumas são na área de baixo impacto ambiental e outras relacionadas com o aumento da produção de componentes que não necessitem de acabamento final após tratamento. Algumas destas vantagens são: flexibilidade no controle de seus parâmetros; boa reprodutibilidade; capacidade de tratamento em temperaturas mais baixas; menores tempos de tratamento; economia de energia, dado que o aporte é feito exclusivamente ao material a ser nitretado; controle na camada e espessura da mesma; possibilidade de nitretação localizada; não causa dano ambiental nem utiliza componentes nocivos à saúde, Alves Jr. (1995).

Este processo apresentava algumas limitações, que com o desenvolvimento dos novos sistemas de controle eletrônicos foram praticamente sanadas. Tais limitações são as seguintes: 
- Aquecimento diferenciado;

- Penetração do plasma em pequenos furos;

- Efeito do catodo ôco;

- Abertura de arcos catódicos.

\section{3 - CORROSÃO DOS AÇOS INOXIDÁVEIS}

A corrosão consiste na deterioração dos materiais pela ação química ou eletroquímica produzida pelo meio, podendo estar ou não associada a esforços mecânicos e o produto de corrosão formado é extremamente pobre em termos destas propriedades. Quando isto ocorre, o metal perde suas qualidades essenciais, tais como resistência mecânica, elasticidade e ductilidade, Ramanathan (1988). Ao se considerar o emprego de materiais na construção de equipamentos ou instalações é necessário que estes resistam à ação do meio corrosivo, além de apresentarem propriedades mecânicas suficientes e caracteristicas de fabricação adequadas. Dependendo do tipo de ação do meio corrosivo sobre o material, os processos corrosivos podem ser classificados em dois grandes grupos, abrangendo todos os casos de deterioração por corrosão:

a- Corrosão Eletroquímica ou Aquosa;

b- Corrosão Química ou Seca.

Os processos corrosivos de natureza eletroquímica apresentam mecanismos semelhantes por apresentarem áreas anódicas e catódicas, entre as 
quais circula uma corrente de elétron e uma corrente de íons. A perda de massa e modo de ataque sobre o material ocorre de formas diferentes.

Em qualquer processo corrosivo existe uma reação anódica (ou oxidação) e uma catódica (ou redução), onde elétrons são cedidos e recebidos respectivamente. A reação mais importante e responsável pelo desgaste do material é a oxidação do metal que ocorre de acordo com a reação abaixo:

$M e^{\circ} \rightarrow M^{2 n+}+2 n e^{-}$

A formação dos íons metálicos é um processo de oxidação, porque envolve a perda de elétrons e o estado de valência do metal aumenta (por exemplo, passa de zero para +2$)$.

No caso dos aços inoxidáveis, ocorrem várias formas de corrosão, tais como corrosão por pites, por frestas, intergranular, sob tensão fraturante, dentre outras.

A corrosão por pite é um tipo de corrosão localizada que ocorre em materiais capazes de se passivarem tais como aços inoxidáveis, $\mathrm{Al}, \mathrm{Ti}, \mathrm{Cu}$, etc, quando expostos a um meio contendo ânions agressivos específicos, em particular cloretos. Nos aços inoxidáveis duplex, a corrosão é altamente influenciada pelas transformações microestruturais que estes aços podem sofrer durante a solidificação ou durante a realização de tratamentos térmicos, devido principalmente, ao fato de que muitas transformações de fases envolvem fases ricas em $\mathrm{Cr}$ causando uma redução uniforme no teor de $\mathrm{Cr}$ do substrato ou, em alguns casos, produzindo a formação de zonas localizadas que são severamente empobrecidas de cromo. A importância do cromo reside em sua capacidade de conferir passividade nas ligas a base de ferro em meios aquosos. O teor mínimo de Cr que permite a formação de um fino (da ordem de ângstron) filme de óxido 
protetor, que isola a liga do ambiente, é $12 \%$ e, ligas com quantidades menores que este valor sofre dissolução ativa.

\subsection{1 - Aspectos Gerais da Corrosão nos Aços Inoxidáveis.}

$\mathrm{O}$ aumento no teor de $\mathrm{Cr}$ nos aços inoxidáveis eleva gradativamente a resistência à corrosão atmosférica, devido à grande afinidade desse elemento pelo $\mathrm{O}_{2}$ e a formação da película de óxido passivante. $\mathrm{O} \mathrm{Cr}$ é o principal elemento responsável pela formação da película superficial passiva (o óxido $\mathrm{Cr}_{2} \mathrm{O}_{3}$ ), devido sua grande afinidade pelo $\mathrm{O}_{2}$. Sob condições oxidantes, $\mathrm{o}$ aço inoxidável não experimenta uma taxa de corrosão significativa (mas isto não quer dizer que ela seja nula). Esses aços, contudo, são atacados por ácido clorídrico $(\mathrm{HCl})$, quando presentes numa atmosfera desprovida de oxigênio. $O$ oxigênio do filme passivo vem ou do oxigênio dissolvido na solução, ou da decomposição da própria água na superfície metálica (chamada reação de desprendimento de $\mathrm{O}_{2}$ ), conforme reação abaixo:

$2 \mathrm{H}_{2} \mathrm{O} \rightarrow \mathrm{O}_{2}^{-}+4 \mathrm{H}^{+}+4 \mathrm{e}^{-}$

Em ligas contendo $\mathrm{Cr}$, a região passiva é iniciada a um potencial mais baixo do que o caso do ferro puro. A região transpassiva resulta da facilidade de oxidação do $\mathrm{Cr}$ no filme passivo passando, de $\mathrm{Cr}^{+3}$ para $\mathrm{Cr}^{+6}$. Em meio aquoso que contém ions haletos, $\mathrm{Cl}^{\prime}, \mathrm{Br}^{\circ}$ ou l', a taxa de corrosão de um aço inoxidável pode aumentar drasticamente em potenciais muito inferiores à transpassividade. A corrosão por pite, de fato, é limitada a pequenos furos, onde a destruição da película protetora, 
formada sobre a superfície do material em determinados pontos da região anódica é explicada em termos de uma competição entre a adsorção de íons cloretos e de $\mathrm{O}_{2}$ em solução. Uhlig (1987), considera que embora o metal tenha uma maior afinidade pelo $\mathrm{O}_{2}$, sob potenciais mais elevados, a adsorção de íons $\mathrm{Cl}^{-}$é favorecida em certas regiões da superfície anódica.

\subsection{2 - Passivação.}

A passivação é um fenômeno que ocorre em metais e ligas, que reduz a velocidade de corrosão, por apresentar uma diminuição da energia livre de Gibbs associada a sua passagem do estado metálico para os produtos de corrosão peculiares. Em alguns casos, a velocidade de corrosão atinge valores tão pequenos, que pode ser considerada desprezível. É o caso, por exemplo, dos aços inoxidáveis, $\mathrm{Al}, \mathrm{Ti}$, etc., em determinados meios onde normalmente o produto de corrosão é um filme de óxido que possui propriedades protetoras e é aderente à superfície metálica Fontana (1987) e Ramanathan (1988). No caso dos aços inoxidáveis, a passivação aumenta a resistência à corrosão por pite. Várias teorias foram propostas para explicar o mecanismo da passivação. Dentre estas, duas são mais utilizadas:

1 - a teoria do filme de óxido;

2 - a teoria da adsorção na superfície metálica de oxigênio ou de ions passivantes.

Os filmes de óxido que se forma em aços inoxidáveis e ligas de alumínio devido ao alto teor de elementos passivantes (por exemplo, Cr e Mo), são camadas 
da ordem de microns, formadas naturalmente sobre a superfície metálica, devido à grande afinidade dos mesmos com o $\mathrm{O}_{2}$, e que atuam como uma nova fase estável entre o metal e a solução, dificultando a difusão iônica e eletrônica e, portanto, exercendo um controle sobre a velocidade de dissolução do metal SzklarkaSmiolowaka (2000). Nos aços inoxidáveis austeníticos AISI 316 o teor de Mo varia de $2-4 \%$, o que melhora substancialmente a resistência à corrosão, e em especial a resistência à corrosão por pites Honeycombe (1985).

A teoria da adsorção tem como base o desalojamento, pelos íons passivantes, de moléculas de água adsorvidas, as quais são necessárias para a hidratação dos íons metálicos, e conseqüentemente para a dissolução anódica.

Esse desalojamento das moléculas de água retarda a reação. Os metais que passivam de acordo com esta teoria são metais que contêm lacunas eletrônicas ou elétrons desemparelhados nos subniveis "d" do átomo. Por exemplo, nos elementos de transição como o $\mathrm{Cr}$, Mo e $\mathrm{Ni}$, os elétrons desemparelhados participam na formação de ligações iônicas fortes com o oxigênio do meio. Em adição, no caso desta teoria, a adsorção do oxigênio do meio é favorecida porque átomos metálicos são mantidos fortemente ligados no retículo espacial Ramanathan (1988). A Figura 03 ilustra esquematicamente a formação e crescimento do filme de óxido em meio aquoso e em meio atmosférico Chao (1981). 


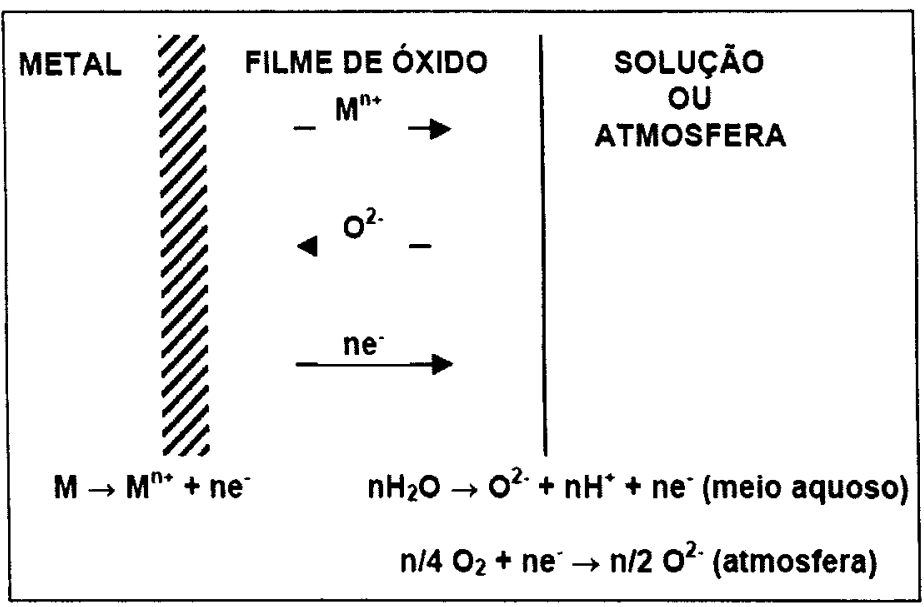

Figura 03 - Representação esquemática de formação e crescimento do filme de óxido em meio aquoso ou em meio atmosférico Chao (1981).

A eficiência do filme de óxido em conferir passividade ao metal depende de suas propriedades físicas, químicas e mecânicas e deve apresentar as seguintes características:

1 - Filme de baixa condutividade iônica cresce lateralmente, acelerando a passivação inicial, e dificulta a difusão de cátions metálicos para o ambiente e de ânions para o metal. Filme de alta condutividade eletrônica mantém os processos anódicos, tais como evolução de oxigênio;

2 - O transporte catiônico, controlado pela quantidade de vazios existentes na rede catiônica (quanto menos vazios existirem mais difícil é o movimento de cátions) $\mathrm{ZnO}, \mathrm{Al}_{2} \mathrm{O}_{3}$ e $\mathrm{Cr}_{2} \mathrm{O}_{3}$, praticamente não apresentam vazios na rede catiônica;

3 - Trincas mecânicas ou térmicas colocam o metal em contato com o ambiente corrosivo.

Em resumo, para estabelecer passividade ao metal base, o filme de óxido deve apresentar as seguintes propriedades:

a - baixa condutividade iônica;

b - boa condutividade eletrônica; 
c - baixa solubilidade no eletrólito e lenta dissolução;

d - estabilidade sobre uma ampla faixa de potencial;

e - boa resistência mecânica e aderência ao metal.

A Figura 04 mostra uma curva de polarização anódica esquemática para aços inoxidáveis. Esta curva fornece alguns parâmetros essenciais para 0 entendimento do comportamento de corrosão desses aços. Quando o potencial é aumentado acima do potencial de corrosão $\left(E_{\text {corr }}\right)$, até um potencial chamado potencial de passivação $\left(E_{p p}\right)$, a densidade de corrente aumenta até atingir um valor crítico chamado densidade de corrente de transição ativa-passiva.

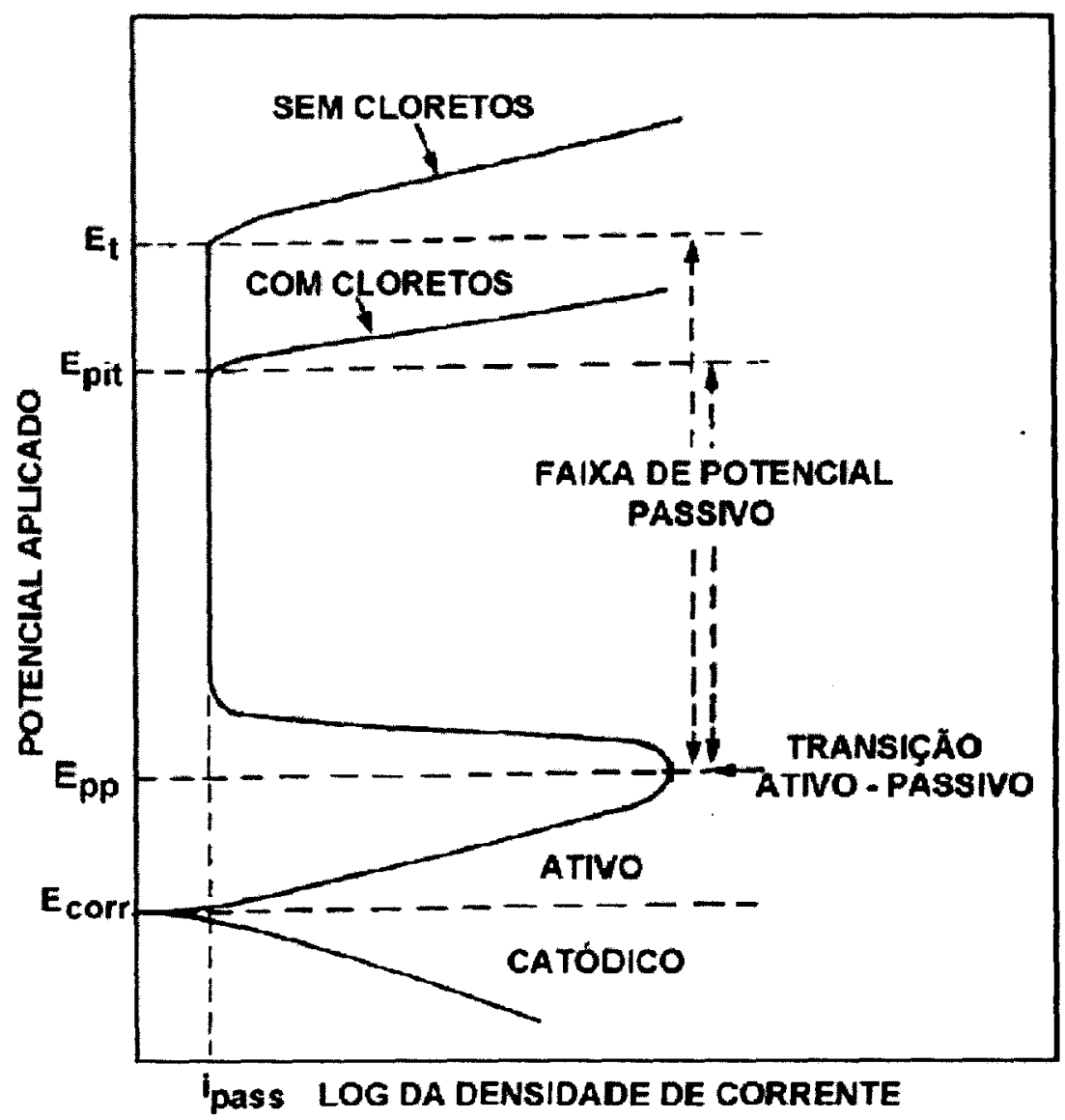

Figura 04- Curva de polarização anódica esquemática para aços inoxidáveis Sedriks (1996). 
A passivação ocorre devido à formação de um filme de óxido proveniente dos produtos de corrosão. Acima do potencial de passivação a densidade de corrente cai bruscamente para um valor conhecido como densidade de corrente passiva $\left(I_{\text {pass }}\right)$, e permanece com este valor sobre uma ampla faixa de potencial. Nesta faixa de potencial, conhecida como faixa de potencial passivo, o filme de óxido permanece intacto, e a corrosão é significativamente muito lenta, Laycock e Newman (1997).

Se o potencial for aumentado continuamente acima da faixa do potencial passivo, a densidade de corrente voltará a crescer acentuadamente. Neste caso, três situações podem ocorrer:

a - Desprendimento de gás oxigênio devido à eletrólise da água, quando o potencial de evolução do oxigênio $\left(\mathrm{EO}_{2}\right)$ é atingido. $\mathrm{O}$ filme passivo nesta condição apresenta baixa resistividade elétrica, e a superfície metálica não alterada se comporta como um eletrodo inerte;

b - Decomposição eletroquímica do filme passivo, provocando novamente a corrosão, quando o potencial transpassivo $\left(E_{1}\right)$ é atingido. Os aços inoxidáveis quando passivados em ácido sulfúrico apresentam camada protetora de $\mathrm{Cr}_{2} \mathrm{O}_{3}$, a qual passa para $\mathrm{Cr}_{2} \mathrm{O}_{7}$ com a transpassivação;

c - Danificação do filme passivo em pontos discretos, quando o potencial atinge o valor do potencial de pite. Aços inoxidáveis, alumínio e suas ligas e $\mathrm{Cr}$ e suas ligas são susceptíveis a corrosão por pite em ambientes contendo íons cloretos (água do mar). 


\subsection{3 - Formação de Pites}

A quebra ou perda da passivação com inicio de corrosão pode ocorrer quando fatores eletroquímicos, mecânicos ou químicos produzem remoção da película passiva. A corrosão por pite é um ataque localizado que ocorre sobre a superfície metálica, e que pode antecipar a falha em serviço de componentes devido à penetração da corrosão no metal, causando a perda de massa e formação de trincas, podendo, neste caso ocorrer corrosão sob tensão fraturante.

Segundo Uhlig (1987), os pites iniciam-se com a quebra da passivação, por meio da nucleação dos mesmos, favorecida sobre a superfície metálica. A interrupção é seguida pela formação de uma célula eletrolítica, onde o anodo é uma minúscula área ativa do metal, e o cátodo é uma considerável área passiva do metal. Esta célula ativa-passiva tem uma grande diferença de potencial caracteristica (aproximadamente 0,5V para aços inoxidáveis série-300), que causa considerável fluxo de corrente acelerando a corrosão do ânodo.

O pite é considerado de natureza autocatalítica, sendo seu crescimento controlado pela taxa de despolarização das áreas catódicas e, uma vez iniciado, cresce por meio de um processo autocatalítico, Newman (1985). As reações eletroquímicas anódicas e catódicas, que constituem a corrosão, se separam durante a formação do pite, e tornam o ambiente local do pite esgotado de reagente catódico (por exemplo, oxigênio), o qual desloca a reação catódica para a superfície exposta, onde este reagente catódico é mais abundante. $\mathrm{O}$ ambiente dentro do pite, torna-se enriquecido de cátions metálicos e a espécie anódica (por exemplo, cloreto), difunde para dentro do pite para manter a neutralidade de cargas por meio do equilíbrio associado com a concentração de cátions. A reação de dissolução anódica no interior do pite é equilibrada pela reação catódica na superfície 
adjacente. O cloreto metálico formado $\left(\mathrm{M}^{+} \mathrm{Cl}\right)$ é hidrolisado pela água como hidróxido e ácido livre. A geração deste ácido diminui o valor do pH no interior do pite, enquanto o pH do volume da solução permanece neutro.

\subsection{4 - Ocorrência dos Pites}

A corrosão por pite segundo Asphahni e Silence (1987), ocorre mais comumente em metais e ligas. Por exemplo, ferro enterrado no solo corrói com a formação de pites rasos (superficiais), mas em aços inoxidáveis, imersos em água do mar, ocorre a formação de pites profundos. As ligas de Al, também estão sujeitas à formação de pite quando imersas em água contendo $\mathrm{Cl}^{-}$e $\circ$ latão apresente este tipo de corrosão, quando imerso em água poluída.

Em meios contendo concentrações de $\mathrm{Cl}^{-}, \mathrm{Br}^{\prime}, \mathrm{F}^{-}$ou $\mathrm{r}^{\prime}$, os materiais que contém ligas à base de (por exemplo, $\mathrm{Fe}$, de $\mathrm{Ni}$, de $\mathrm{Co}$, e ligas de Ti) tendem a corroer em áreas especificas, e formar pites profundos, Asphahni e Silence (1987). Segundo esses autores a severidade do pite varia com o logaritmo da concentração de cloreto, que é um ânion de um ácido forte, relativamente pequeno com alta difusibilidade que, quando presente, destroi a passivação, Szklarska-Smialowaka (1999). Na ausência de passividade, tal como em cloretos metálicos alcalinos e cloretos metálicos monoxidantes (por exemplo, cloreto de estanho $\mathrm{SnCl}_{2}$, ou cloreto de níquel $\mathrm{NiCl}_{2}$ ), o pite não ocorre, embora, a corrosão geral ou uniforme possa ser apreciável em tais ambientes Galvele (1981). 


\subsection{5 - Pites Metaestáveis e Estáveis}

A ocorrência de oscilações da densidade de corrente durante a realização dos ensaios de corrosão por pites, tem sido explicada pela consecutiva formação e repassivação de pites microscópicos (micro pites) denominados de pites metaestáveis Frankel (1987). Os pites metaestáveis são muitos pequenos, crescem e repassivam em poucos segundos. Quando os pites metaestáveis nucleiam e começam a crescer, a corrente aumenta e diminui após um tempo muito curto.

Os pites metaestáveis ocorrem mais freqüentemente em potenciais próximos do potencial de pite. Frankel et al. (1987) e Szklarsha-Smialowaka (1999) pesquisaram sobre pites metaestáveis em aços, e estabeleceram critério para estabilização de pites, isto é, que $I_{\text {pite }} / r_{\text {pite }}$ deve exceder $4 \times 10^{-2} \mathrm{~A} / \mathrm{cm}^{2}$ para estabilizar o crescimento. ( $I_{\text {pite }}$ é a corrente dentro do pite, e $r_{\text {pite }}$ é o raio do pite). Abaixo deste valor os pites metaestáveis são formados.

De acordo com Buzza e Alkire (1995), a estabilidade do pite depende do tamanho do pite, da duração do potencial em circuito aberto. Segundo estes autores, a um particular potencial aplicado, uma concentração crítica, adjacente à superfície do pite é necessária para o pite permanecer ativo.

Frankel et al (1987) sugeriram que pites metaestáveis, formados em aços inoxidáveis, são estabilizados pela queda ôhmica associada com o depósito poroso formado sobre os pites e que a repassivação é presumida ocorrer se esse depósito poroso for rompido. Quando o depósito poroso sobre o pite é quebrado, a solução do pite é diluída e ocorre a repassivação.

Um pite se desenvolve quando as condições em seu interior são tais que os pites estão no estado ativo. Galvele (1976) sugeriu que os pites estáveis crescem continuamente se o valor crítico de $X . I_{\text {pite }}$ (profundidade do pite $(X)$ vezes densidade 
de corrente do pite $\left.\left(I_{\text {pite }}\right)\right)$ for excedido, o qual depende do material e da composição química do mesmo. Ele desenvolveu esta regra levando em consideração a acidificação da solução do pite.

Conseqüentemente, tanto $\circ \mathrm{pH}$ quanto os íns cloretos são necessários para o crescimento do pite. De acordo com este autor, a magnitude do $\mathrm{pH}$ está ligada com a concentração de íons cloretos na solução do pite. As mudanças no pH conduzem a um processo autocatalítico de crescimento do mesmo. Entretanto, a manutenção do processo autocatalítico só é possível caso não ocorra repassivação da superfície do pite.

\section{4. - DESGASTE MICRO-ABRASIVO DE REVESTIMENTOS}

De forma geral desgaste pode ser definido como uma mudança cumulativa e indesejável nas dimensões das peças, motivada pela remoção gradual de partículas discretas de superficies em contato e com movimento relativo, devido, predominantemente, a ações mecânicas.

Desgaste por abrasão é o mais comum e, segundo Eyre (1978), 50\% de todos os problemas de desgaste na indústria são devidos à abrasão. Dada a sua importância, muitos trabalhos têm sido realizados na área de desgaste abrasivo e, um grande número de métodos de ensaios tem sido usado para avaliar a resistência à abrasão dos materiais. Nestes métodos de ensaio a perda de massa é usada para determinar a taxa de desgaste. Entretanto, a perda de massa não é a única forma para medir o desgaste; Hutchings citado em Shipway (1999), discutiu recentemente métodos onde outras medidas (por exemplo, geométricas) podem ser usadas para calcular a taxa de desgaste. Um destes métodos é o de desgaste 
micro-abrasivo, onde uma esfera é girada contra uma amostra na presença de uma suspensão com partículas abrasivas finas, formando uma calota de desgaste com geometria bem definida, que pode ser medida de um modo simples para obter medidas do volume desgastado. A figura geométrica da superficie de desgaste consiste de uma calota esférica. Uma medida do diâmetro da calota quando ela intercepta a superfície da amostra permite que o volume e massa do material que foi removido sejam calculados. O teste tem sido empregado para avaliar a resistência ao desgaste de uma ampla gama de materiais, inclusive metais, cerâmicas, polímeros, e camadas duras, Shipway (1999).

\subsection{1 - Mecanismos de Desgaste Microabrasivo}

O ensaio de desgaste micro abrasivo tem despertado muita atenção por ser adequado para o exame tanto de camadas finas resistentes ao desgaste quanto de materiais monolíticos, com abrasivos finos. É necessária muita perícia na interpretação de dados experimentais visto que, mudanças nas condições do ensaio, ou até mesmo no material ensaiado, podem alterar radicalmente 0 comportamento das partículas abrasivas, Ayala et al. (2004). Trezona et. al. (1999), estudaram o efeito dos parâmetros no ensaio de desgaste micro abrasivo de aços ferramentas. Eles mostraram que o mecanismo de desgaste predominante depende da força normal, da concentração de partículas do abrasivo na lama, da natureza do material ensaiado e de fatores relacionados à natureza e do tamanho e formato das partículas do abrasivo.

Um requisito fundamental de um ensaio de desgaste padrão é que ele forneça medidas confiáveis e reprodutíveis. Porém, taxas e mecanismos de 
desgaste podem variar amplamente com mudanças nas condições do ensaio, tais como carga e velocidade de deslizamento. Gates (1998) fez uma análise critica sobre a tradicional classificação da abrasão a dois corpos e a três corpos e propôs uma classificação do mecanismo de desgaste em desgaste abrasivo por deslizamento e desgaste abrasivo por rolamento.

No desgaste abrasivo por deslizamento as partículas abrasivas, que atuam como uma aspereza dura fica aderida à esfera do ensaio, deslizando sobre a superficie do material a ser desgastado. Com isso, na direção do desgaste é produzida uma série de riscos paralelos. Já no desgaste abrasivo por rolamento, a partícula abrasiva rola sobre a superfície da amostra, produzindo uma grande quantidade de indentações. Diferentemente do desgaste abrasivo por deslizamento, neste tipo de desgaste não fica evidentes a direção do desgaste, Trezona e Hutchings (1999).

A figura 05 apresenta os mecanismos de desgaste em função da concentração das partículas abrasivas na lama e da carga aplicada no ensaio de desgaste.

Nesta figura, observa-se que o rolamento, característico de desgaste abrasivo a três corpos, predomina quando são utilizadas lamas abrasivas com alta concentração de partículas abrasivas e quando são aplicadas cargas baixas. Segundo Trezona et al. (1999), com o aumento da carga aplicada e da concentração das partículas abrasivas na lama, o mecanismo de rolamento ainda prevalece, uma vez que a indentação na superfície da amostra, por causa das partículas se dá suavemente, Adachia e Hutchings (2004). 


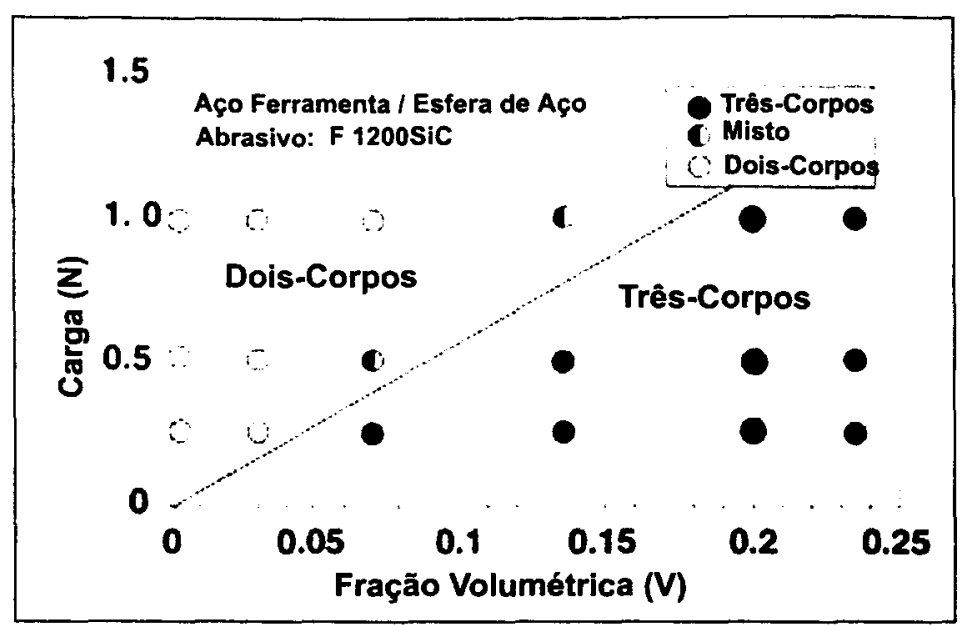

Figura 05-Mecanismos de desgaste microabrasivo para aço ferramenta usando uma esfera de aço Adachia e Hutchings (2003).

Observa-se também que o deslizamento, característico do desgaste abrasivo a dois corpos, é caracterizado pela utilização de lamas com baixas concentrações de partículas abrasivas e cargas elevadas. No movimento da esfera, o riscamento da superfície ocorre quando uma grande quantidade de partículas abrasivas fica engastada na superfície da esfera, as quais atuam como penetradores fixos. Com o aumento da carga aplicada, as partículas indentam mais profundamente a superfície do material produzindo vários riscos paralelos na superfície da mesma, Adachia e Hutchings (2003).

$\mathrm{Na}$ figura 06 nota-se uma pequena região de transição de mecanismos na qual podem ocorrer concomitantemente o deslizamento e o rolamento das partículas abrasivas. É a simplicidade e a reprodutibilidade do processo de desgaste microabrasivo que faz seu uso tão atrativo.

O ensaio de desgaste micro-abrasivo foi proposto por Rutherford e Hutchings nos anos 90. Este ensaio oferece algumas vantagens quando comparado aos outros ensaios tribológicos: ele requer uma pequena área de ensaio e os coeficientes de desgaste intrínsecos de ambos os materiais e camadas podem ser avaliados simultaneamente a partir de seus dados combinados. A Figura 07 
mostra um diagrama esquemático do mecanismo do ensaio de desgaste microabrasivo.
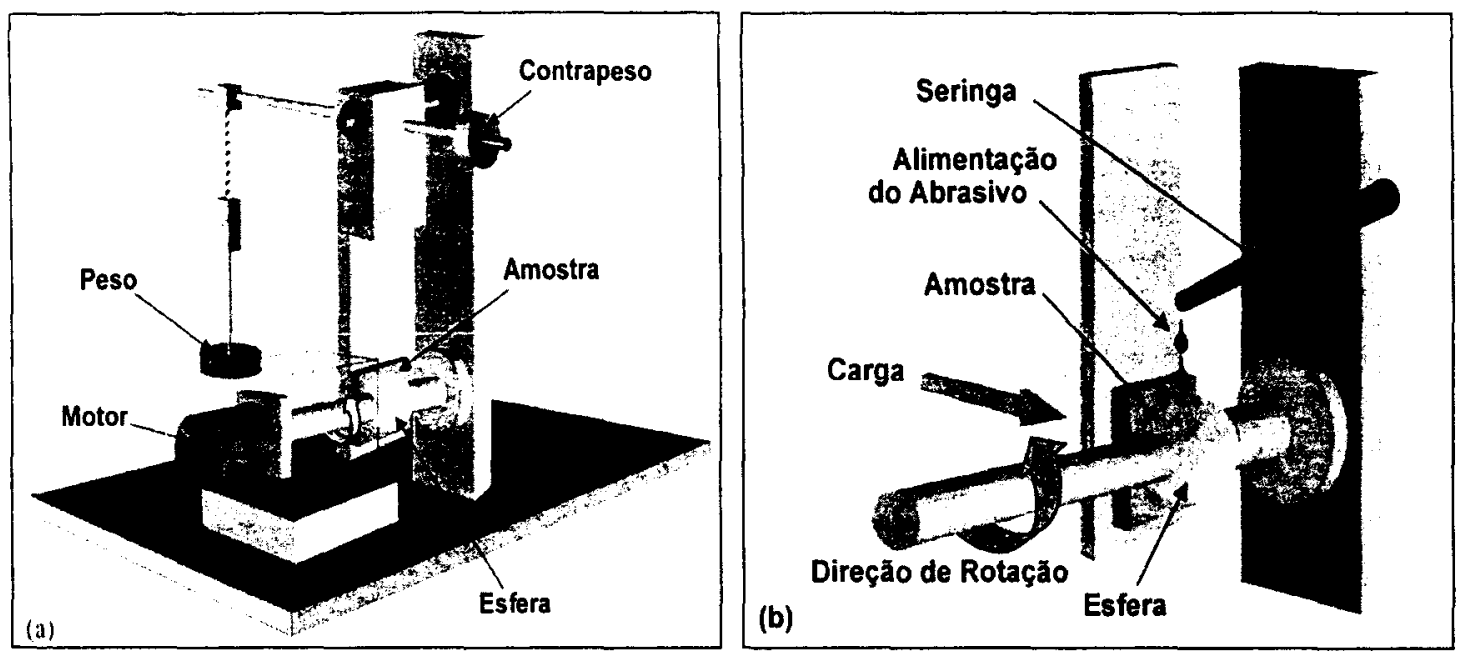

Figura 06- Desenho esquemático mostrando (a) equipamento experimental e (b) detalhes da interface de contato e alimentação do abrasivo Adachia e Hutchings (2003).

\subsection{2- Princípio Básico do Mecanismo de Desgaste Microabrasivo}

No ensaio micro-abrasivo a lama abrasiva é gotejada no contato entre a esfera e a amostra. Quando ocorrer perfuração da camada, as medidas do diâmetro total da calota e do diâmetro da calota no substrato podem indicar taxas de desgaste diferentes para o substrato e a camada.

Neste método, uma esfera de raio " $R$ " é girada contra uma amostra na presença de uma lama com partículas abrasivas finas. A geometria da calota do desgaste é esférica, e o volume do desgaste pode então ser calculado pelas medidas do diâmetro ou da profundidade da calota. O volume do desgaste está diretamente relacionado com a distância percorrida e com a força normal de acordo com a seguinte relação: 
$V=\kappa S N$

onde;

$\kappa$ - é o coeficiente de desgaste ou taxa de desgaste especifico $\left(\mathrm{Nm}^{-1}\right)$;

S - é a distância percorrida pela amostra (m);

$N$ - é a força normal (N).

Para uma calota de desgaste com geometria esférica produzida por uma esfera de raio " $R$ " numa amostra inicialmente plana, sem perfuração da camada o volume de desgaste pode ser calculado de acordo com a seguinte relação;

$V=\frac{\pi h^{4}}{64 R} \quad$ para $h<<<R$

Onde:

$R$ - é o raio da esfera $(\mathrm{mm})$;

h - é a profundidade da calota $(\mu \mathrm{m})$;

V-é o volume de desgaste $\left(\mathrm{mm}^{3}\right)$;

Esta relação também pode ser escrita em função do coeficiente de desgaste $(\kappa)$, escrevendo a equação (3) em função de $(\kappa)$ e substituindo na equação (4), obtém-se;

$k=\frac{\pi h^{4}}{64 R} \frac{1}{S N}$

Quando ocorrer a perfuração da camada, o procedimento que foi desenvolvido por Rutherford e Hutchings (1997) pode ser usado. Neste caso devese levar em consideração tanto a taxa de desgaste da camada quanto do substrato, que podem ser obtidas pela seguinte relação:

$S N=\frac{1}{k_{c}} V_{C}+\frac{1}{k_{s}} V_{s}$

Onde; 
$V_{\mathrm{s}}$ é o volume de desgaste do substrato $\left(\mathrm{mm}^{3}\right)$;

$V_{c}$ é o volume de desgaste da camada $\left(\mathrm{mm}^{3}\right)$;

$\kappa_{\mathrm{s}}$ é o coeficiente de desgaste do substrato $\left(\mathrm{Nm}^{-1}\right)$;

$\kappa_{\mathrm{c}}$ é o coeficiente de desgaste da camada $\left(\mathrm{Nm}^{-1}\right)$.

Existem diferentes formas de implementar a equação (6). Pode ser resolvida usando uma aproximação de múltiplos quadrados. Os coeficientes de desgaste $K_{\mathrm{c}}$ e $\kappa_{\mathrm{s}}$ são considerados desconhecidos. Entretanto, a equação é bastante instável, por causa da relação entre $V_{c} \in V_{s}$.

A melhor metodologia é reescrever a equação (6) como uma função linear. Convencionalmente duas formas são usadas. A primeira onde Vt é o volume total usado, que é dado pela relação:

$\frac{S N}{V_{t}}=\left(\frac{1}{k_{c}}-\frac{1}{k_{s}}\right) \frac{V_{c}}{V_{t}}+\frac{1}{k_{s}}$

Onde,

$V_{t}$ é o volume de desgaste total da amostra $\left(\mathrm{mm}^{3}\right)$.

A formula é mais estável quando $\frac{V_{c}}{V_{t}}<0,5$. Esta equação relaciona o volume total desgastado com o volume da camada. A segunda forma de reescrever a equação (7) é;

$$
\frac{S N}{V_{1}}=\left(\frac{1}{k_{s}}-\frac{1}{k_{c}}\right) \frac{V_{s}}{V_{t}}+\frac{1}{k_{c}}
$$

Nesta segunda formula, a equação relaciona o volume total desgastado com o volume do substrato. Como em qualquer ensaio de desgaste, há um grande número de parâmetros que afetam os resultados dos ensaios por micro-abrasão, que são:

Os materiais abrasivos;

O tamanho do abrasivo; 
A forma do abrasivo;

O tipo de fluido da suspensão;

A carga;

A velocidade;

O tipo de material da esfera;

A condição superficial da esfera.

O material abrasivo é muito importante. O fator principal é a dureza do abrasivo, e em geral, quanto mais duro o abrasivo, maior é a taxa de desgaste. É importante considerar o valor relativo de dureza entre o abrasivo, o material da esfera e da amostra.

O tamanho do abrasivo também é importante, uma vez que a força de friç̧ão que age entre as superfícies de ensaio e as partículas abrasivas limitará a granulometria máxima de abrasivo que pode ser arrastado para a interface entre a esfera e a amostra. Se nenhum abrasivo estiver presente na interface, o mecanismo de desgaste muda radicalmente. Para o tamanho de esferas que normalmente são usadas ( $25 \mathrm{~mm}$ de diâmetro), este limite estará na faixa $10-20 \mu \mathrm{m}$ de diâmetro. Esta é a razão principal pela qual este ensaio é mais apropriado para o uso com abrasivos finos.

Em todos os ensaios abrasivos, a forma das partículas abrasivas é muito importante. Abrasivos com formas mais angulares transmitem tensões mais altas quando são pressionados e se movem contra a amostra. Por isso é provável que o dano abrasivo e desgaste sejam mais altos para partículas abrasivas de forma mais angulares.

O efeito da carga aplicada e da concentração da lama abrasiva é semelhante. Quando a carga é aumentada, existe uma transição do mecanismo de desgaste de rolamento a três corpos para deslizamento a dois corpos, Trezona et 
al. (1999). Da mesma forma, quando a fração volumétrica do abrasivo é aumentada, existe uma transição do mecanismo de desgaste de rolamento a dois corpos para deslizamento a três corpos.

A figura 07 mostra um diagrama esquemático da geometria da calota obtida no substrato (a) e na camada (b) através de um ensaio microabrasivo. Nesta figura, "R" é o raio da esfera, " $t$ " é a espessura da camada, "h" é a profundidade da calota, "a" é a diagonal interna e "b" é a diagonal externa da calota, que são utilizados para o cálculo do volume de desgaste ou perda de massa.

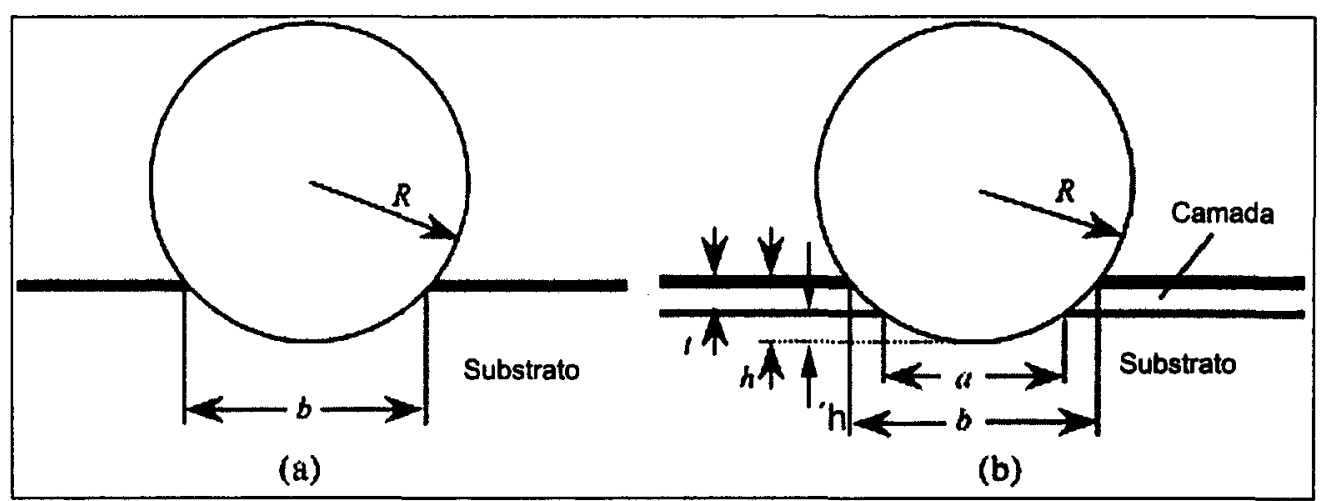

Figura 07- Diagrama esquemático mostrando a geometria da calota formada pelo ensaio microabrasivo com uma esfera de raio R.(a) no substrato e (b) na camada obtida Kusano, et. al. (2004).

Segundo Rutherford e Hutchings (1997) neste mecanismo de desgaste, as calotas esféricas podem ser obtidas na superfície do substrato ou camadas em intervalos de tempo interrompidos, por exemplo; $2,5,10,15,20,25$ e 30 minutos dependendo da resistência e coeficiente de atrito do substrato ou camadas. Em cada um desses intervalos os diâmetros das calotas esféricas são medidos com o auxilio de um microscópio ótico, para determinação do volume desgastado e da espessura do revestimento quando a camada for perfurada. 


\section{Determinação da espessura do revestimento:}

Considere a figura 07. Nessa figura, $R$ é o raio da esfera de ensaio, "a" é o diâmetro interno da calota, "b" é o diâmetro externo e t é a espessura da camada, como; $t=h-h^{\prime}, \therefore h=t+h^{\mid}$, então a espessura da camada é;

$$
t=h-h^{1} \quad \therefore h=t+h^{1}
$$

Considerando, $(b-a)=2 x$ e $(a+x)=y$; portanto,

$$
\begin{array}{ll}
x=\frac{(b-a)}{2} & \therefore b=2 x+a \\
y & =a+x
\end{array}
$$

O raio da esfera $\mathrm{R}\left(=\frac{\phi}{2}\right)$, o diâmetro da calota externa (b), e o diâmetro da calota interna (a) e a profundidade da calota (h), se relacionam;

$$
R^{2}=\left(\frac{b}{2}\right)^{2}+(R-h)^{2} \quad \therefore h(2 R-h)=\frac{b^{2}}{4}
$$

Como $\mathrm{h} \ll \mathrm{R}$, pode-se considerar que, $2 R-h \cong 2 R$ de modo que a equação (12) pode ser escrita da seguinte forma;

$h \cong \frac{b^{2}}{8 R}$

Esta aproximação dá uma boa estimativa da profundidade da calota (h), introduzindo nos cálculos finais erros menores que 1\% Rutherford e Hutchings (1996). Da mesma forma que a equação (13), pode se obter o valor da profundidade da calota usando o diâmetro interno da mesma, pela equação;

$$
h \cong \frac{a^{2}}{8 R}
$$

Substituindo as equações (13) e (14) na equação (09), obtém-se o valor da calota considerando-se a perfuração da camada; 


$$
h=\frac{b^{2}}{8 R}-\frac{a^{2}}{8 R} \quad \therefore h=\frac{\left(b^{2}-a^{2}\right)}{8 R}
$$

Substituindo a equação (10) na equação (15), tem-se;

$$
\begin{aligned}
& h=\frac{(2 x+a)-a^{2}}{8 R} \Rightarrow h=\frac{\left(4 x^{2}+4 x a\right)}{8 R} \Rightarrow h=\frac{4 x(x+a)}{8 R} \\
& \therefore h=\frac{x(x+a)}{2 R}
\end{aligned}
$$

Substituindo a equação (13) na equação (16), obtém-se;

$$
h=\frac{x y}{2 R} \quad \text { ou } \quad h=\frac{x y}{\phi}
$$

Portanto, a espessura da camada e profundidade da calota obtida no ensaio de desgaste microabrasivo podem ser obtidas por meio de cálculos matemáticos simples, usando um microscópio ótico para medida dos valores de $x$ e y $e$ relacionando-os com os valores dos diâmetros interno e externo da calota obtida. 


\section{3 - MATERIAIS E MÉTODOS}

A figura 08 mostra um fluxograma do procedimento experimental realizado no presente trabalho.

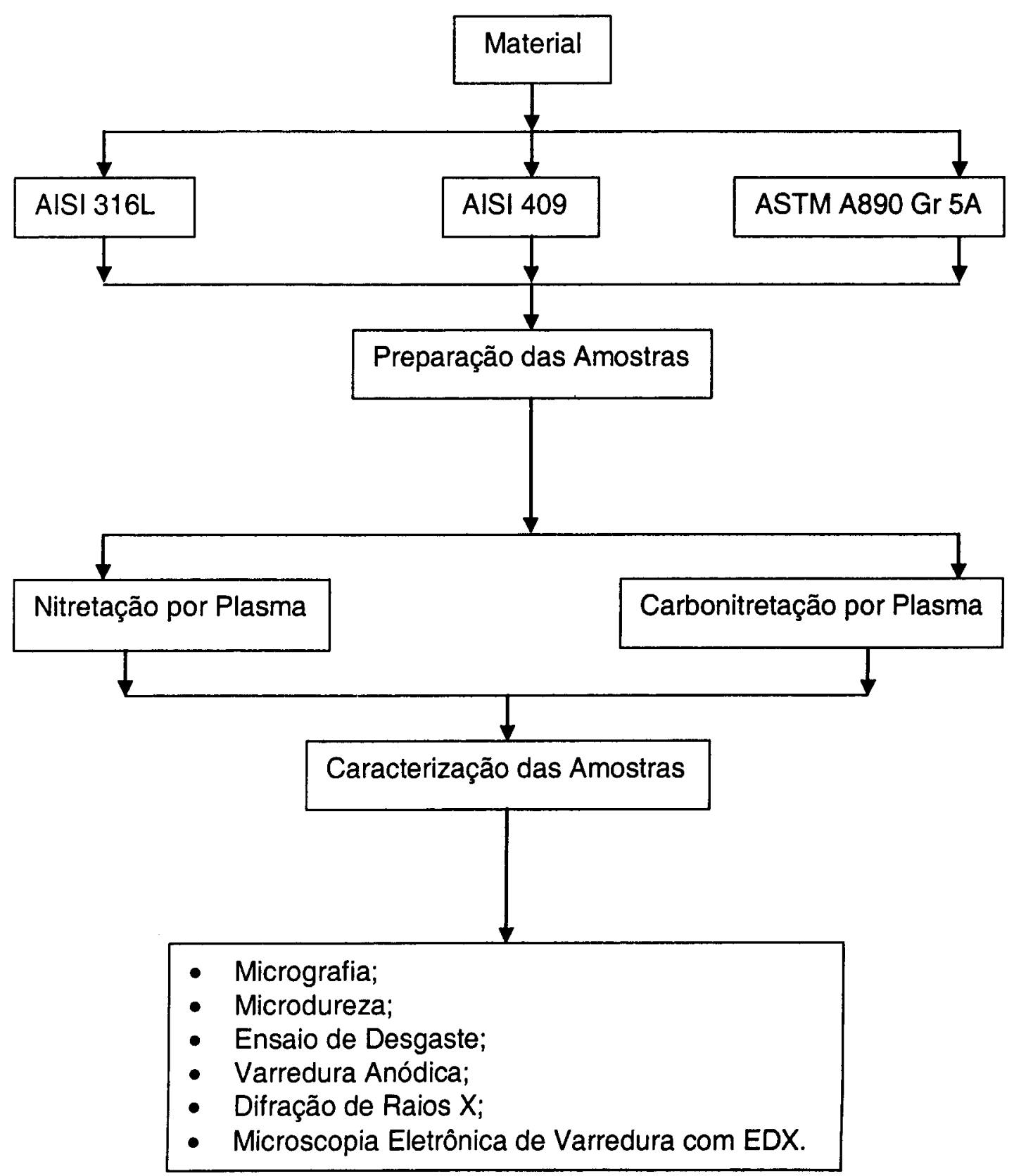

Figura 08 - Fluxograma da seqüência dos procedimentos experimentais realizados neste trabalho. 


\section{1 - EQUIPAMENTO PARA NITRETAÇÃO E CARBONITRETAÇÃO}

O equipamento de nitretação e carbonitretação por plasma utilizado no presente trabalho foi construído no Departamento de Engenharia, Aeronáutica e Automobilística, da Escola de Engenharia de São Carlos. Em linhas gerais, ele consiste basicamente de uma câmera, uma fonte elétrica de alimentação, um sistema de vácuo e um sistema de aquisição de dados. A figura 09 mostra o esquema do equipamento utilizado para os processos de nitretação e carbonitretação por plasma utilizados no presente trabalho.

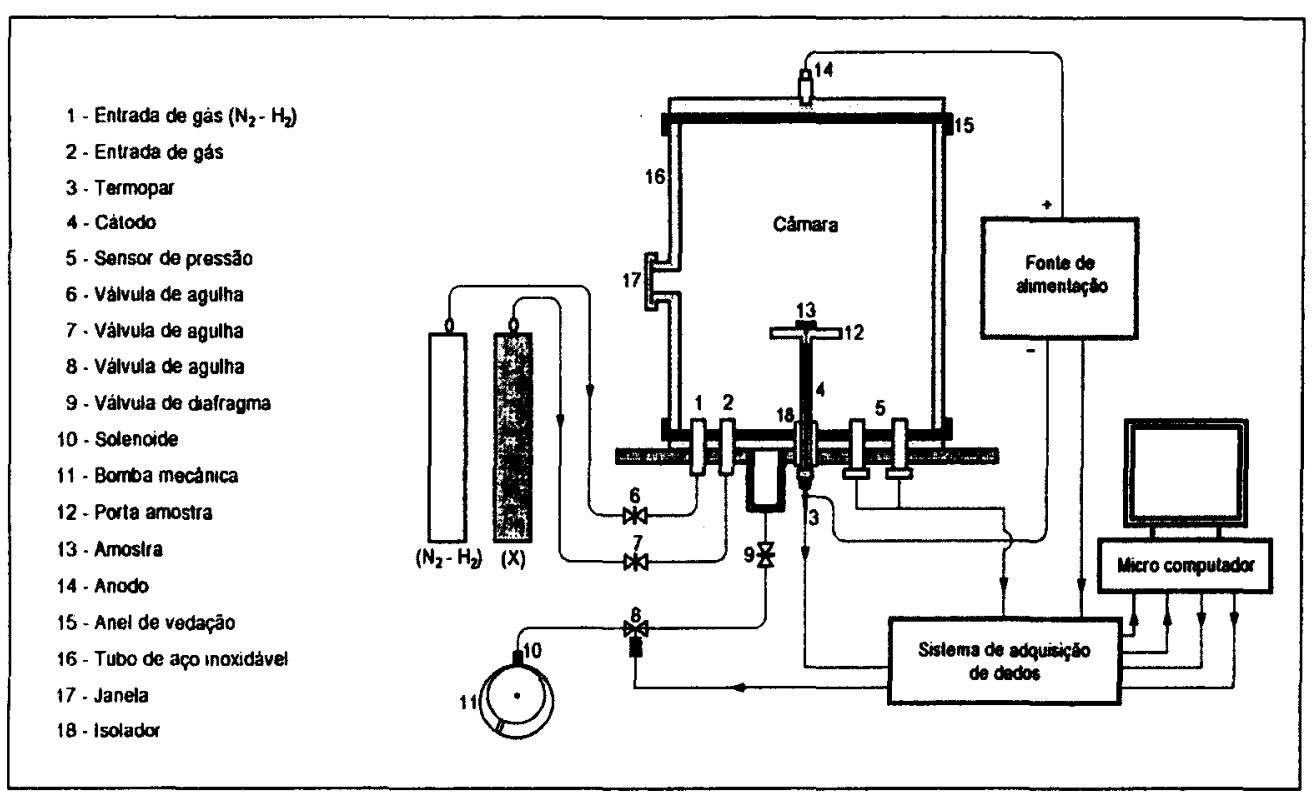

Figura 09 - Esquema do equipamento de nitretação e carbonitretação por plasma utilizados nos experimentos.

A câmera é constituída de um tubo de aço inoxidável, com altura de $30 \mathrm{~cm}$ e diâmetro de $30 \mathrm{~cm}$, resultando num volume de $0,021 \mathrm{~m}^{3}$, com duas flanges, também de aço inoxidáveis, utilizadas para fechar a câmera. A flange superior, que é móvel, está ligada a um terminal positivo da fonte de potencia, juntamente com a parede da câmera, constituindo 0 ânodo. A flange inferior possui sete furos para entrada $e$ 
saida dos gases, sendo que no centro passa o termopar de cromel-alumel, eletricamente isolado. Além da entrada e saída de gases, alguns furos são ocupados por conexões da instrumentação de leitura e controle, como: sensores de pressão, válvulas de vácuo da câmera, sensores de temperatura, e outros. O portaamostra (catodo), constituido de um disco de aço inoxidável com diâmetro de $10 \mathrm{~cm}$ e com espessura de $0,5 \mathrm{~cm}$ é apoiado sobre uma blindagem elétrica, permitindo uma maior eficiências nos tratamentos realizados. Os ions positivos do plasma são direcionados para a superfície da amostra, em contato elétrico com o anôdo. A vedação das partes superior e inferior é feita com perfil " $L$ " de viton. Através de uma janela de vidro posicionada na parte mediana da parede da câmera pode ser observado o processo de nitretação ou carbonitretação por plasma.

A fonte de potência consiste de um sistema de retificação que recebe tensão da rede $(220 / 60 \mathrm{~Hz})$. Possui uma potencia máxima de $800 \mathrm{~V}$, em corrente direta (DC), ajustável continuamente, com uma potência máxima de 2KVA. Além da tensão contínua, uma tensão pulsada quadrada, também pode ser obtida, com freqüência (f) variável de 1 a $10 \mathrm{~Hz}$, e ciclo de trabalho $(w)$ de 30 a $90 \%$.

A câmera é evacuada por um sistema de vácua constituído por uma bomba de vácua mecânica rotativa, modelo E2M8 da Edwards, seguida por uma válvula de isolamento tipo solenóide (PV25EK-Edwards), montada na linha de entrada. A válvula de isolamento é eletricamente ligada em paralelo com o motor. Uma válvula diafragma está situada na entrada da câmera.

O sistema de aquisição de dados é composto de uma série de mostradores digitais fixados no painel do equipamento que medem a pressão, corrente, tensão, temperatura, ciclo de trabalho e freqüência, e permite o monitoramento de todos as variáveis necessárias para o processo de nitretação e carbonitretação. A figura 10 apresenta a foto do equipamento de nitretação e carbonitretação usados. 


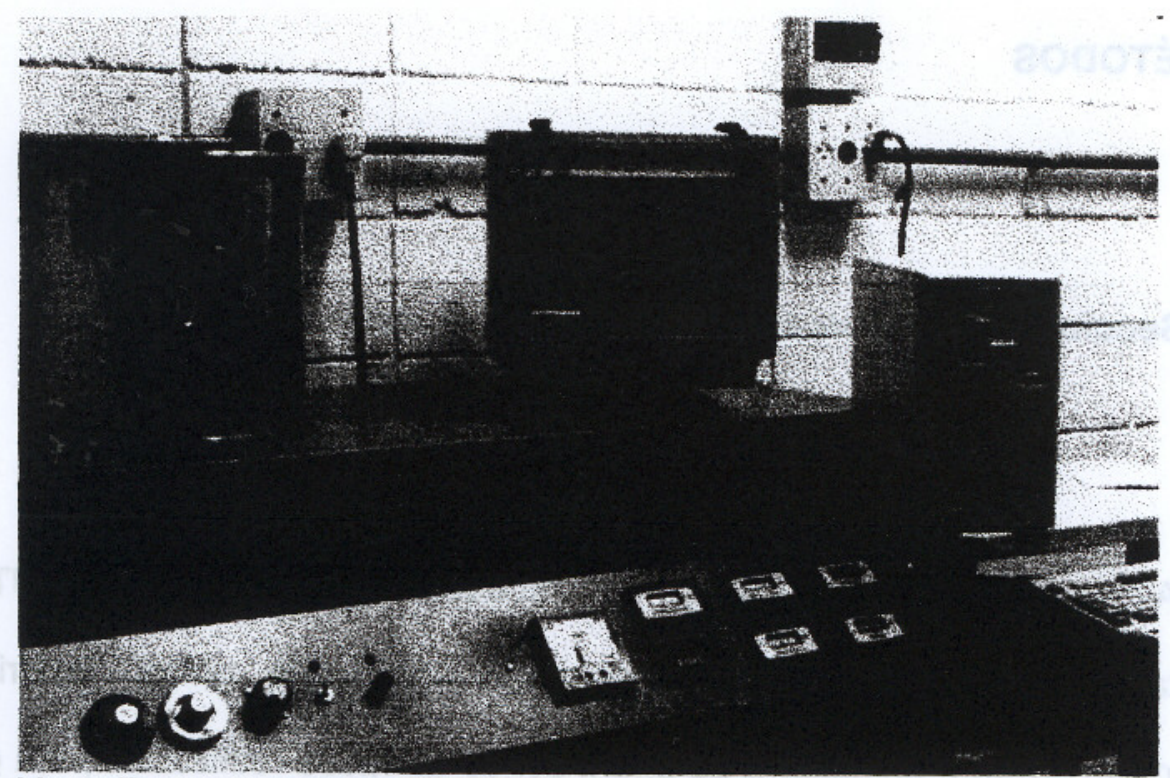

Figura 10 - Foto do equipamento de nitretação e carbonitretação por plasma utilizado no trabalho

\section{2 - MATERIAL.}

Para os tratamentos de nitretação e carbonitretação foram utilizados os aços inoxidáveis austenítico AISI 316L, ferrítico AISI 409 e aço inoxidável super duplex ASTM A890 Gr5A nas condições solubilizadas. A temperatura de solubilização foi de $1050^{\circ} \mathrm{C}$ durante 30 minutos com resfriamento em água. A tabela 03 apresenta as composições químicas nominais das ligas.

Tabela 03 - Composições químicas das ligas (\% em peso)

\begin{tabular}{|c|c|c|c|c|c|c|c|c|c|}
\hline 0,028 & 17,06 & 10,48 & 2,44 & 1,49 & 0,53 & - & - & Balanc. \\
\hline 0,030 & 11,25 & 0,06 & 0,11 & 0,74 & 0,49 & - & - & Balanc. \\
\hline 0,023 & 24,81 & 7,52 & 4,05 & 0,62 & - & 0,30 & 0,176 & Balanc. \\
\hline
\end{tabular}




\section{3-MÉTODOS}

\subsection{1 - Seccionamento das amostras a serem tratadas}

As amostras foram cortadas numa máquina de corte do tipo CUT-OFF de alta rotação, refrigerada. Foram produzidos corpos de prova cilíndricos com diâmetro de $12 \mathrm{~mm}$ e espessura de $3 \mathrm{~mm}$, sendo as faces retificadas para garantir o paralelismo das mesmas.

\subsection{2 - Lixamento e polimento das amostras}

As superfícies das amostras foram lixadas manualmente, utilizando-se a seguinte seqüência de lixas: 150, 220, 320, 400, 600, 1200 e 2000 mesh. Após o lixamento as amostras foram polidas com alumina $\left(\mathrm{Al}_{2} \mathrm{O}_{3}\right)$ em solução aquosa com tamanhos de partículas de 0,3 e 0,05 $\mu \mathrm{m}$.

\subsection{3 - Limpeza das amostras}

Um dos estágios mais importantes na nitretação e carbonitretação é a limpeza. As amostras, geralmente estão impregnadas com resíduos oriundos dos processos realizados anteriormente. Devido a isso, as amostras foram limpas com água corrente e álcool após cada estágio da operação de lixamento e polimento e, 
posteriormente foram secadas com jato de ar quente. Anteriormente aos tratamentos de nitretação e carbonitretação as mesmas foram submetidas a uma limpeza com éter de petróleo em um vibrador ultra-sônico durante 20 minutos.

\subsection{4 - Tratamentos de Nitretação e Carbonitretação por Plasma}

Após a limpeza, as amostras foram colocadas na câmara e produzido um vácuo de $8 \times 10^{-2} \mathrm{mbar}$. Os tratamentos de nitretação e carbonitretação por plasma foram realizados com corrente continua. Para o tratamento de nitretação usou-se uma mistura gasosa de $20 \% \mathrm{~N}_{2}-80 \% \mathrm{H}_{2}$ e para o de carbonitretaçăo uma mistura gasosa de $78 \% \mathrm{H}_{2}-20 \% \mathrm{~N}_{2}-2 \% \mathrm{CH}_{4}$. As temperaturas utilizadas para nitretação e carbonitretaçăo foram de 400,450 e $500^{\circ} \mathrm{C}$, durante 5 e 10 horas, respectivamente. Nas tabelas 04 e 05 são apresentados os parâmetros utilizados para a nitretaçăo e a carbonitretaçăo. As amostras foram resfriadas dentro da câmara sob vácuo. No caso do tratamento de carbonitretação, ensaios preliminares de tratamentos durante 5 horas resultaram em camadas de pequenas espessuras, o que levou ao uso do tempo de 10 horas para a produção de maiores espessuras.

Tabela 04 - Condições de tratamentos para nitretaçăo por plasma.

\begin{tabular}{|l|l|l|l|l|l|}
\hline AISI 316 & 400 & 5 & 5 & 421 & 288 \\
\hline AISI 316 & 450 & 5 & 5 & 466 & 356 \\
\hline AISI 316 & 500 & 5 & 5 & 483 & 421 \\
\hline AISI 409 & 400 & 5 & 5 & 441 & 294 \\
\hline AISI 409 & 450 & 5 & 5 & 474 & 353 \\
\hline AISI 409 & 500 & 5 & 5 & 487 & 388 \\
\hline Superduplex & 400 & 5 & 5 & 423 & 292 \\
\hline Superduplex & 450 & 5 & 5 & 439 & 357 \\
\hline Superduplex & 500 & 5 & 5 & 449 & 425 \\
\hline
\end{tabular}


Tabela 05 - Condições de tratamentos para carbonitretação por plasma.

\begin{tabular}{|l|c|c|c|c|c|}
\hline \multicolumn{7}{|c|}{ AIS1316 } & 400 & 5 & 10 & 485 & 252 \\
\hline AIS1316 & 450 & 5 & 10 & 523 & 338 \\
\hline AIS1316 & 500 & 5 & 10 & 527 & 374 \\
\hline AIS1409 & 400 & 5 & 10 & 499 & 271 \\
\hline AIS1409 & 450 & 5 & 10 & 536 & 298 \\
\hline AIS1409 & 500 & 5 & 10 & 545 & 357 \\
\hline Superduplex & 400 & 5 & 10 & 495 & 265 \\
\hline Superduplex & 450 & 5 & 10 & 503 & 290 \\
\hline Superduplex & 500 & 5 & 10 & 524 & 350 \\
\hline
\end{tabular}

\subsection{5 - Caracterização das amostras.}

Para a análise metalográfica, as amostras foram cortadas e embutidas em baquelite dura, para evitar abaulamentos das camadas nitretadas e carbonitretadas durante o polimento das amostras. Para $\circ$ ataque metalográfico das mesmas, foram utilizados os reagentes químicos; Água Régia e Beraha II adequados para a revelação das camadas nitretadas e carbonitretadas e da microestrutura do material.

Após a nitretação e carbonitretação as amostras foram submetidas à análises metalográficas e ensaios de microdureza. As fotomicrografias foram obtidas em um microscópio ótico Carl-Zeiss modelo Axiotech, com a técnica de contraste de interferência diferencial, para identificação e caracterização das camadas obtidas e respectivos substratos. 


\subsection{6 - Ensaios de Microdureza.}

Na determinação das microdurezas utilizou-se um microdurômetro Micromet 2104 digital, com cargas de 25gf. O tempo de aplicação da carga, a preparação da superfície e o procedimento seguido na obtenção dos valores de dureza estão de acordo com a norma [ASTM E384-99e1].

\subsection{7 - Ensaios de Desgaste.}

Os ensaios de desgastes adesivos foram realizados num abrasômetro do tipo "Calotest" utilizando uma carga de $38 \mathrm{~N}$. Os desgastes foram realizados em condição não lubrificada e a temperatura ambiente. Cada amostra foi ensaiada num total de 50 minutos e a cada $5,10,15$ e 20 minutos, parava-se o ensaio e realizavam-se as medidas dos diâmetros das calotas obtidas para se determinar o volume do desgaste. Com os resultados obtidos, foram construídos gráficos relacionando a perda de massa (volume) em função da distância percorrida em metros. 


\subsection{8 - Microscopia Eletrônica de Varredura e EDX.}

Foram observadas as secções transversais das amostras, para se avaliar as espessuras das camadas de nitretos, carbonitretos, zona de difusão e interface camada/substrato. Foram realizadas microanálises em algumas das amostras nitretadas e carbonitretadas.

\subsection{9 - Curvas de Polarização Anódicas.}

Foram realizados curvas de polarização anódicas potenciodinâmicas para determinação dos potenciais de corrosão e de corrosão por pites dos materiais nitretados e carbonitretados por plasma. Por este método, varia-se o potencial aplicado em função do tempo (velocidade de varredura).

As curvas de polarização potenciodinâmicas foram determinadas utilizandose um potenciostato modelo Autolab II interfaceado com um microcomputador e uma solução desaerada de $\mathrm{NaCl}(3,5 \%) \mathrm{com}$ pH neutro, e a temperatura ambiente. Os testes foram realizados de acordo com a norma ASTM G 61 (1991), sendo as curvas de polarização potenciodinâmicas obtidas com varredura do potencial de 500 a $1200 \mathrm{mV}$ e velocidade de varredura de $1 \mathrm{mV} / \mathrm{seg}$. Potenciais superiores a $1200 \mathrm{mV}$ geram correntes superiores a $5,0 \times 10^{-3} \mathrm{~A}$, o que não é permitida pela norma, e as mesmas estão associadas á decomposição da água com evolução de oxigênio $\left(\mathrm{O}_{2}\right)$

A célula utilizada no experimento foi a de 3 eletrodos, de acordo com a norma ASTM G5 (1994). As amostras foram imersas na célula eletroquímica e 
conectadas ao potenciostato por meio de fios de cobre e de aço inoxidável, juntamente com o eletrodo de referência (Calomelanos Saturado) e o contra eletrodo (Eletrodo de Platina).

\subsubsection{0 - Difração de Raios X.}

As análises por difração de raios- $\mathrm{X}$ foram realizadas nas amostras nitretadas e carbonitretadas e no substrato, para identificação das fases presentes, em um Difratômetro Rigaku Rotaflex. Utilizou-se a técnica de varredura contínua e tubo de radiação de cobre, com uma constante de tempo de 2 segundos, uma velocidade de varredura de $2 \% /$ minutos e uma faixa angular $2 \theta$ variando de 20 a $120^{\circ}$. As fases e compostos presentes nas amostras foram identificados com o auxílio dos dados do JCPDC - "Joint Commitee on Power Diffraction Standards". 


\section{4 - RESULTADOS E DISCUSSÃO}

\section{1 - ANÁLISES MICROGRÁFICAS E MEDIDAS DE MICRODUREZAS DAS CAMADAS PRODUZIDAS}

\subsection{1 - Amostras Nitretadas}

São apresentadas nas figuras 11(a), (b) e (c) as micrografias óticas e na figura 09(d) as medidas de microdurezas do aço AISI 316 Litretado nas temperaturas de 400 , 450 e $500^{\circ} \mathrm{C}$ durante 5 horas. Observa-se a presença do substrato austenítico e sobre o mesmo as camadas nitretadas produzidas, que variaram com o aumento da temperatura de tratamento. Nas amostras nitretadas a 400 e $450^{\circ} \mathrm{C}$ formou-se uma camada monofásica denominada de fase " $S$ " ou "austenita expandida" enquanto que na nitretada a $500^{\circ} \mathrm{C}$ ocorreu também a formação de uma camada escura de nitretos de cromo sobre a fase " $S$ ".

Tais fases foram identificadas por meio de análises de raios-X (fig 32). A denominação de austenita expandida é devida à expansão causada pela supersaturação de nitrogênio na austenita, sendo que o teor máximo de nitrogênio situa-se entre 20 e 40 (\%at.), Larisch et al. (1999), enquanto que na austenita 
normal é de 8,7(\%at.), Bell (2002); Li (2001); Li et al. (2002); Pranevicius et al. (2001); Sun et al. (1999) e Thaiwathana et al. (2002).

Segundo alguns autores a fase "S" pode, também, ser uma solução sólida metaestável, supersaturada com nitrogênio com uma estrutura cfc desordenada, uma vez que as posições dos picos de difração de raios $X$ da fase "S" desviam-se das posições ideais de um reticulado cristalino cúbico de face centrada (cfc), austenítico, Bell (2002); Dearnley (2002) e Thaiwathana et al. (2002).

Observa-se nas figuras $11(a)$ e (b), que após 0 ataque com 0 reagente químico, as camadas nitretadas apresentam uma aparência clara, indicando uma resistência à corrosão superior à do substrato austenítico (ver figura 32). Na figura 09(c), verifica-se que a parte superior da camada foi atacada, devida à formação de nitretos de cromo (fase escura).

Segundo Bell (2002); Sun et al. (1999); e Thaiwatthana et al. (2002), em tratamentos de nitretaçăo por plasma realizado em temperaturas inferiores a $450^{\circ} \mathrm{C}$, ocorre apenas à difusão intersticial do nitrogênio para a formação da fase " $S$ " ou austenita expandida e, em temperaturas superiores a $450^{\circ} \mathrm{C}$, além da difusão intersticial do nitrogênio na austenita e da decomposição da austenita expandida em fases mais estáveis, ocorre também a difusão substitucional do cromo, que facilita a formação dos nitretos de cromo.

Na figura 11(d) são apresentados os perfis de microdurezas em função das profundidades das camadas nitretadas. Verifica-se em todos os casos a efetividade dos tratamentos no aumento da dureza superficial do aço e que a temperatura de nitretação afeta os niveis de durezas das camadas. A camada nitretada a $500^{\circ} \mathrm{C}$ apresentou os niveis de microdurezas mais elevados, bem como uma maior profundidade, devido à presença de nitretos de cromo e à alta concentração de nitrogênio na camada clara (fase "S"). 


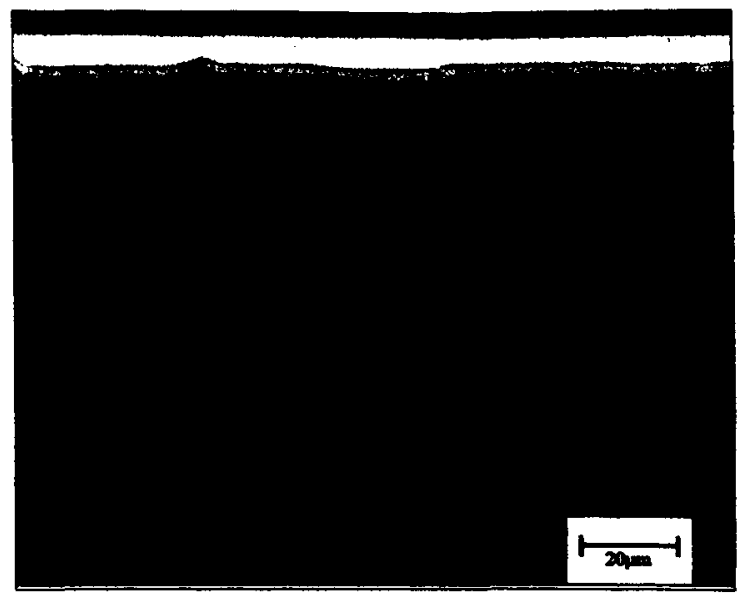

(a) $400^{\circ} \mathrm{C}$.

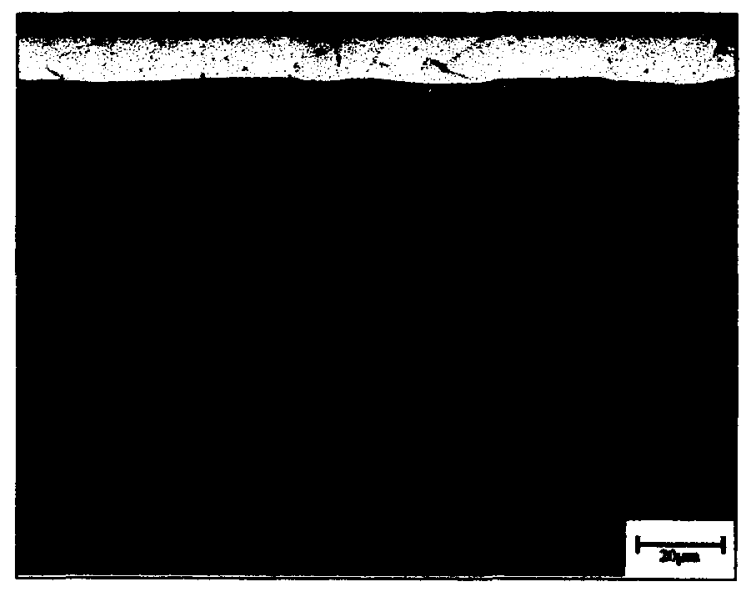

(b) $450^{\circ} \mathrm{C}$.

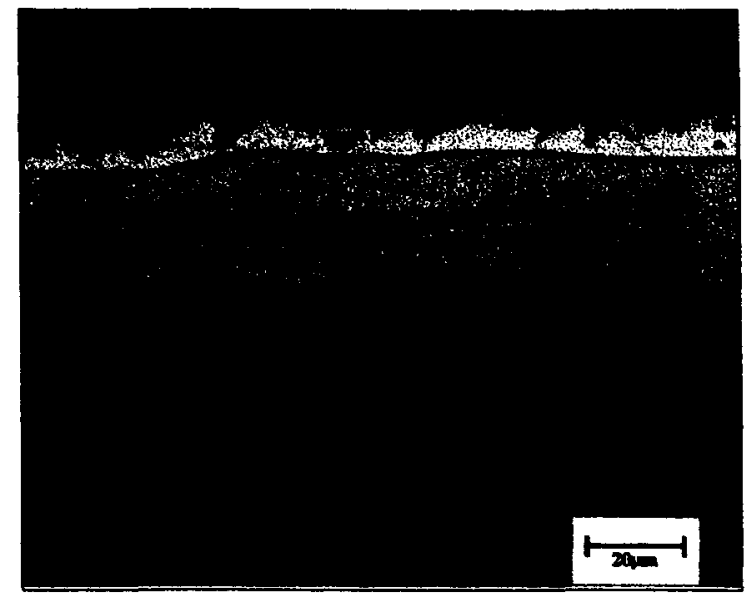

(c) $500^{\circ} \mathrm{C}$.

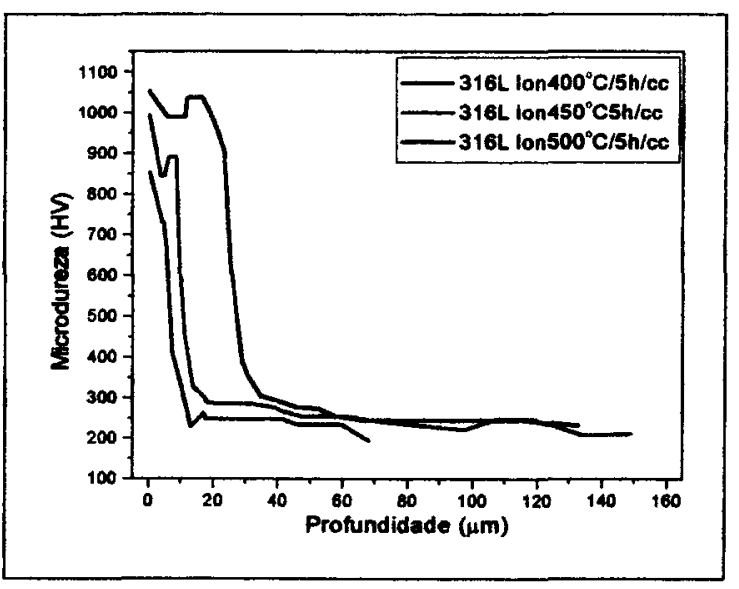

(d) Microdureza.

Figura 11 - Micrografias óticas e curvas de microdurezas para o aço AISI 316L nitretado a diferentes temperaturas.

Nas figuras 12(a), (b) e (c) são mostradas as micrografias óticas e na figura 12(d) os perfis de durezas do aço super duplex nitretado nas temperaturas de 400 , 450 e $500^{\circ} \mathrm{C}$. Verifica-se a presença do substrato austeno/ferrítico e, sobre o mesmo as camadas obtidas. Observa-se que o reagente químico utilizado para revelar a microestrutura provoca um ataque diferenciado entre as duas fases, de forma que a ferrita é atacada com maior intensidade, devida à sua menor resistência à corrosão, enquanto que a austenita permanece clara demonstrando 
sua maior resistência à corrosão. Verificam-se diferenças significativas nos comportamentos das duas fases quanto às camadas formadas sobre as fases ferrita e austenita. No tratamento realizado a $400^{\circ} \mathrm{C}$ formou-se uma camada homogênea sobre ambas as fases. Já no caso das temperaturas maiores, ocorreu sobre a ferrita a formação de camadas constituídas de nitretos de cromo a partir da temperatura de $450^{\circ} \mathrm{C}$, devido provavelmente ao maior teor de cromo desses aços, bem como o particionamento preferencial de cromo para a ferrita, disponibilizando-o para a formação de nitretos, fato este que refletiu diretamente nas resistências à corrosão do aço, prejudicando-a, enquanto que na austenita as camadas constituíram-se unicamente da fase $S$, devido também ao particionamento preferencial do nitrogênio para a austenita, o que contribuiu para a formação e estabilização da fase $S$.

No perfil de microdureza (figura 12(d)), verifica-se que a amostra nitretada a $500^{\circ} \mathrm{C}$ apresentou os maiores valores de durezas superficiais, devido à formação de nitretos de cromo e também da alta concentração de nitrogênio na fase " $S$ ". No caso da amostra nitretada a $400^{\circ} \mathrm{C}$, não foi possível medir a dureza da camada produzida devido à sua pequena espessura $(4 \mu \mathrm{m})$. 


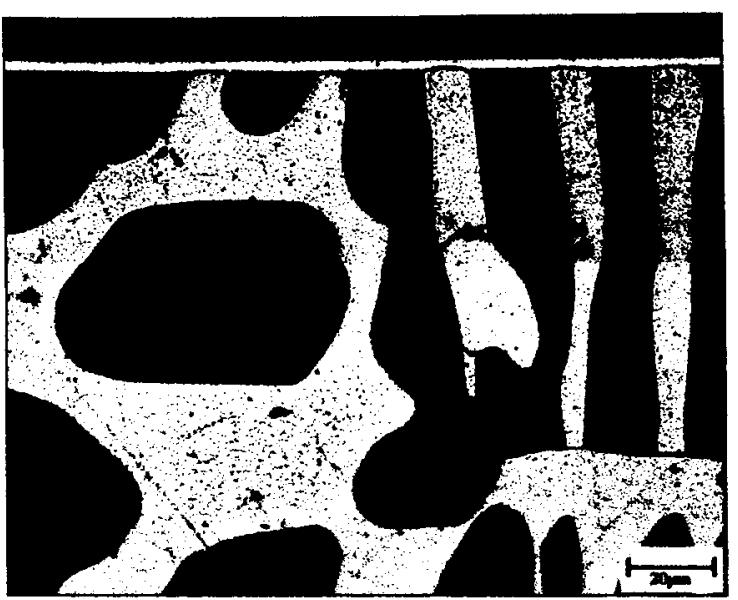

(a) $400^{\circ} \mathrm{C}$.

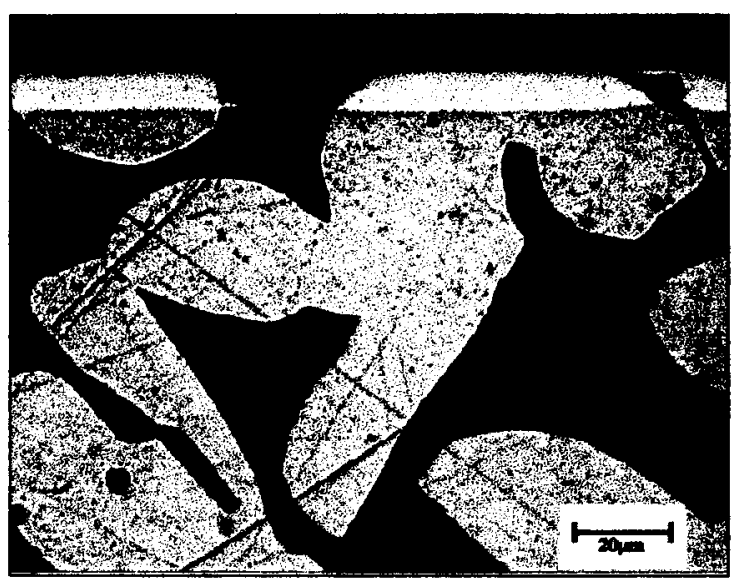

(b) $450^{\circ} \mathrm{C}$.

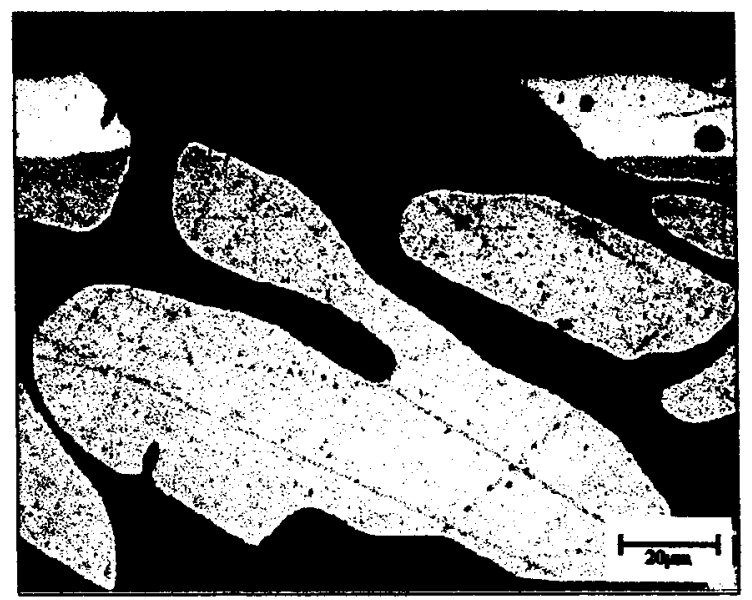

(c) $500^{\circ} \mathrm{C}$.

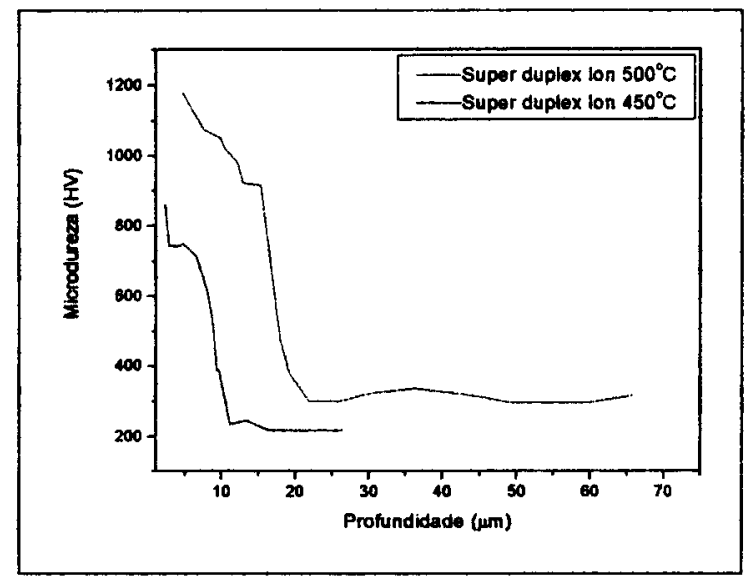

(d) Microdureza.

Figura 12 - Micrografias óticas e curvas de microdurezas para 0 aço superduplex ASTM A890 Gr 5 A nitretado a diferentes temperaturas.

Nas figuras 13(a), (b) e (c) são mostradas as micrografias óticas e na figura 13(d) as medidas de microdurezas do aço AISI 409 nitretado nas temperaturas de 400,450 e $500^{\circ} \mathrm{C}$ durante 5 horas. 


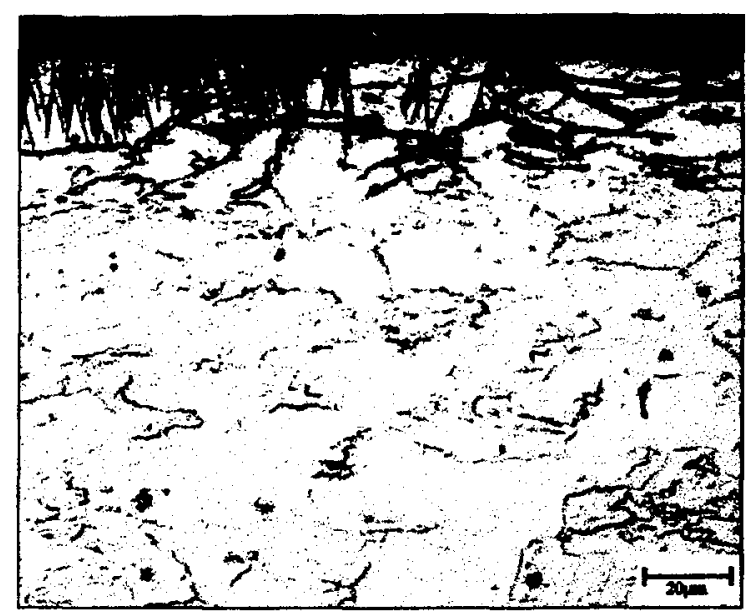

(a) $400^{\circ} \mathrm{C}$.

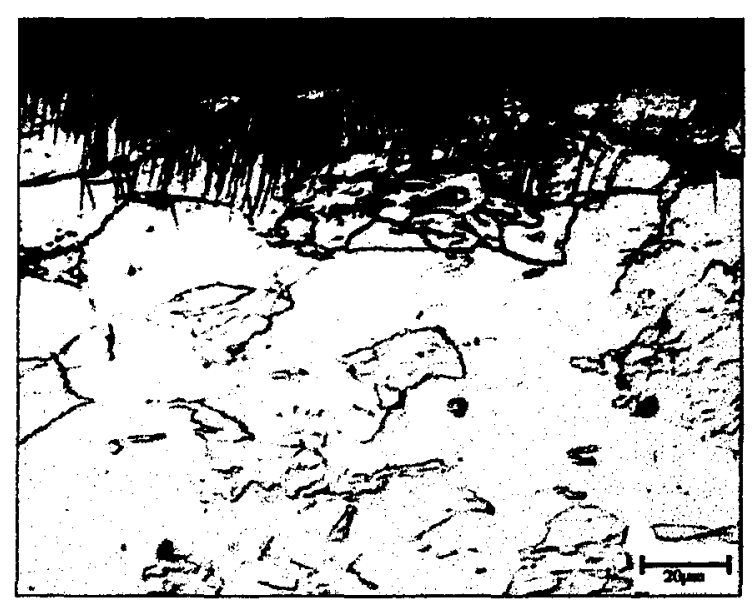

(b) $450^{\circ} \mathrm{C}$.

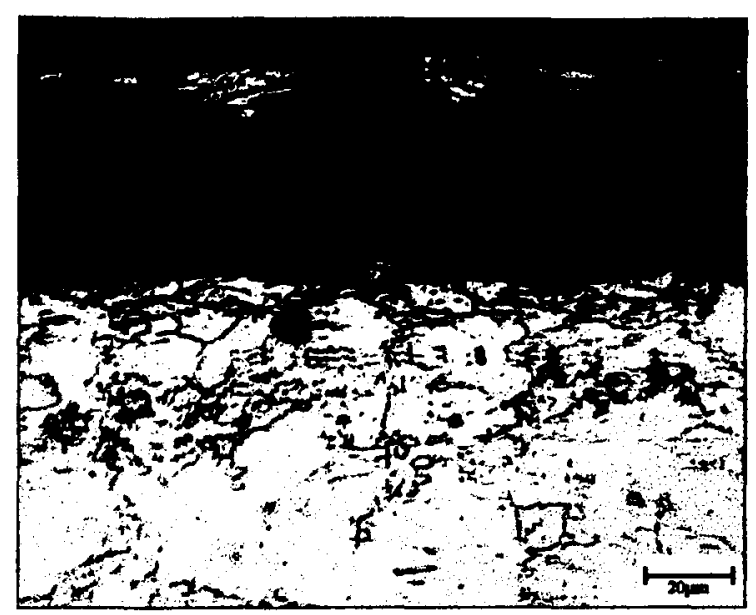

(c) $500^{\circ} \mathrm{C}$.

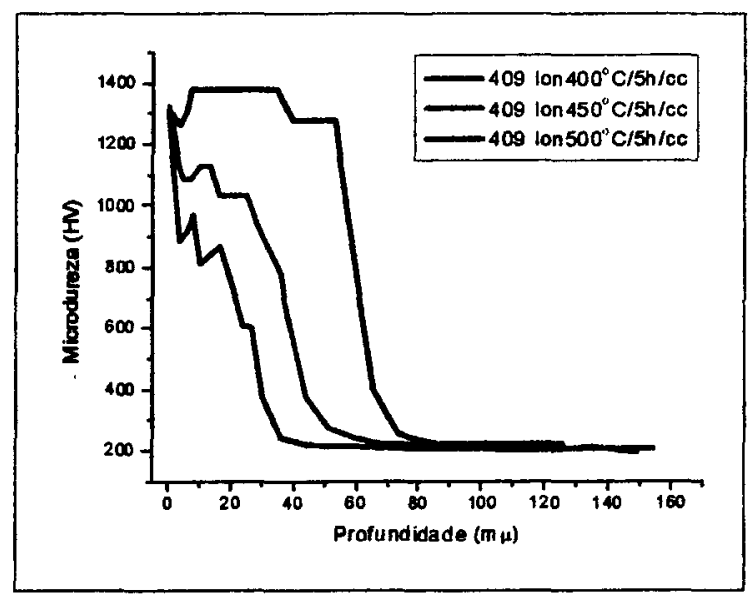

(d) microdureza.

Figura 13 - Micrografias óticas e curvas de microdurezas para o aço AISI 409 nitretado a diferentes temperaturas.

Verificam-se variaçōes morfológicas nas camadas, decorrentes das temperaturas de tratamento utilizadas. Observa-se o crescimento de uma fase acicular, provavelmente nitretos de ferro e, de uma outra fase escura nos contornos de grãos. No caso do tratamento a $500^{\circ} \mathrm{C}$, verifica-se a formação de uma fase mais espessa e escura que corresponde a nitretos de cromo. Essa camada apresenta um nivel de dureza elevado e uniforme em toda a sua espessura.

Na figura 14, observa-se o aumento da espessura da camada em funçăo do aumento da temperatura de nitretação. A partir de $450^{\circ} \mathrm{C}$ inicia-se a formação de 
nitretos de cromo e, também, ocorre à decomposição da austenita expandida (metaestável), em fases mais estáveis tais como os nitretos de ferro. Gemma e Kawakami (1989), consideram que a diferença na cinética de nitretação está associada à formação e decomposição da austenita expandida ou fase "S".

De acordo com seu modelo cinético, a decomposição da fase "S" de alto teor de nitrogênio em alta temperatura fornecerá nitrogênio livre para acelerar a difusão do mesmo no substrato. Essa formação e decomposição da fase "S" atingem uma condição de equilibrio dinâmico, de forma que o nitrogênio livre em excesso é fornecido continuamente durante o processo de nitretação, favorecendo a formação de nitretos de cromo e de ferro (ver figura 25(d)).

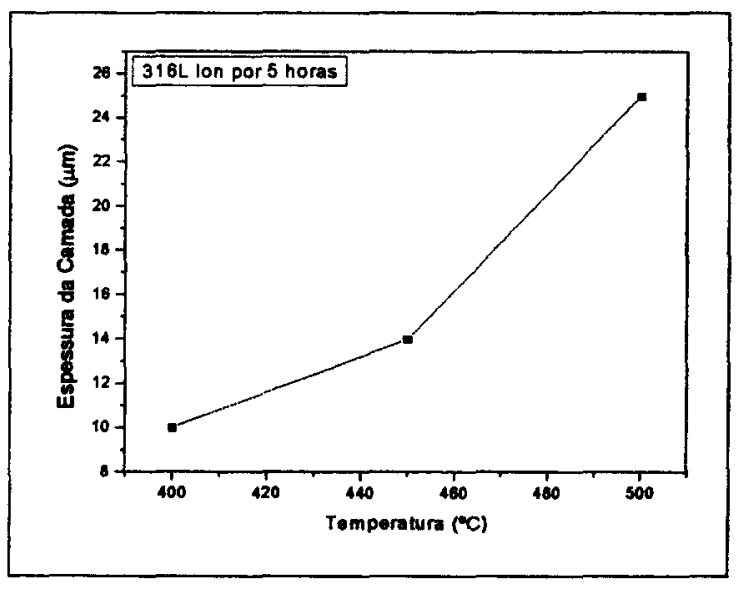

(a)

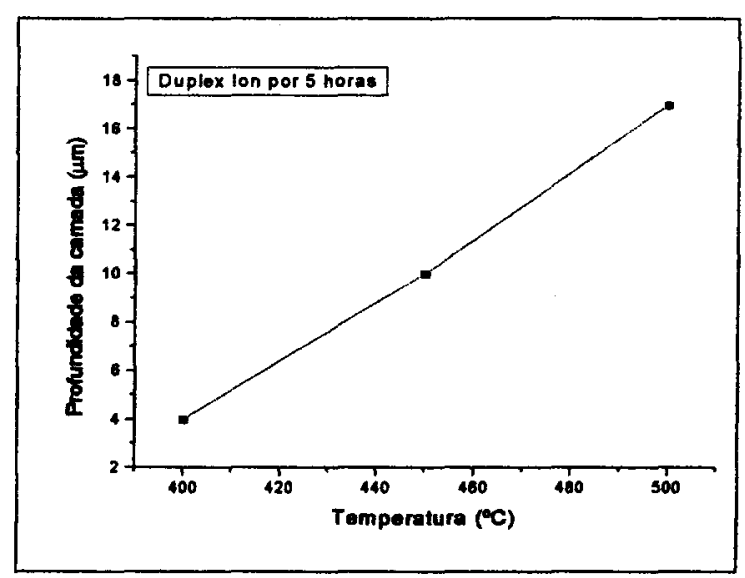

(b)

Figura 14 - Espessura da camada nitretada em função da temperatura, (a) AISI 316L e (b) Super duplex ASTM A890 Gr 5A.

Segundo Jánosi et al (2000) em tratamentos de nitretação por plasma realizados em temperaturas mais baixas, a precipitaçăo de nitretos de cromo é completamente suprimida e uma camada nitretada branca é produzida com uma 
dureza muito alta e excelente resistência à corrosão, inclusive melhor que a do substrato, fato este de acordo com os resultados obtidos no presente trabalho. Esta camada foi primeira identificada por Zhang e Bell (1985) nos aços inoxidáveis austeníticos, tendo uma estrutura do tipo cfc, sendo uma austenita supersaturada com nitrogênio, com um parâmetro de rede diferente do das fases austenita $(\mathrm{Fe}-\gamma) \mathrm{e}$ nitreto de ferro $\left(\gamma^{\prime}-\mathrm{Fe}_{4} \mathrm{~N}\right)$. Ela foi denominada de fase "S" ou "austenita expandida".

\subsection{2 - Amostras Carbonitretadas.}

São apresentadas nas figuras de 15(a) a (c) as micrografias óticas e na figura 15(d) as medidas de microdurezas do aço AISI $316 \mathrm{~L}$ carbonitretado nas temperaturas de 400,450 e $500^{\circ} \mathrm{C}$ durante 10 horas.

Verificam-se os substratos austeníticos e a formação das camadas carbonitretadas sobre os mesmos.

$\mathrm{Na}$ amostra carbonitretada a $400^{\circ} \mathrm{C}$ ocorreu a formação de uma camada branca monofásica, também denominada de fase " $\mathrm{S}$ " ou austenita expandida rica em nitrogênio e carbono sobre o substrato austenítico. No caso do tratamento a $500^{\circ} \mathrm{C}$, observa-se à formação de uma fase escura constituida provavelmente de nitretos e carbonitretos de cromo, sobre a camada branca que é fortemente atacada pelo reagente químico utilizado para revelação da microestrutura, indicando sua baixa resistência à corrosão, característica de fases ricas em nitretos de cromo. 


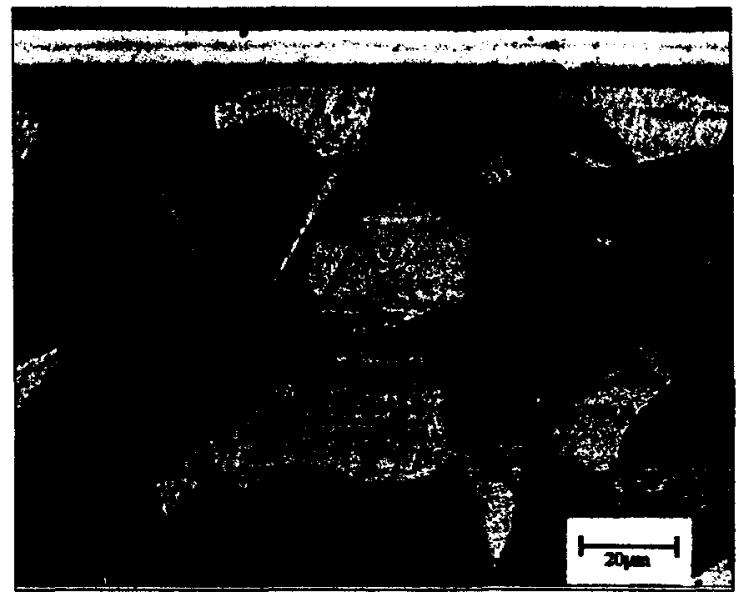

(a) $400^{\circ} \mathrm{C}$.

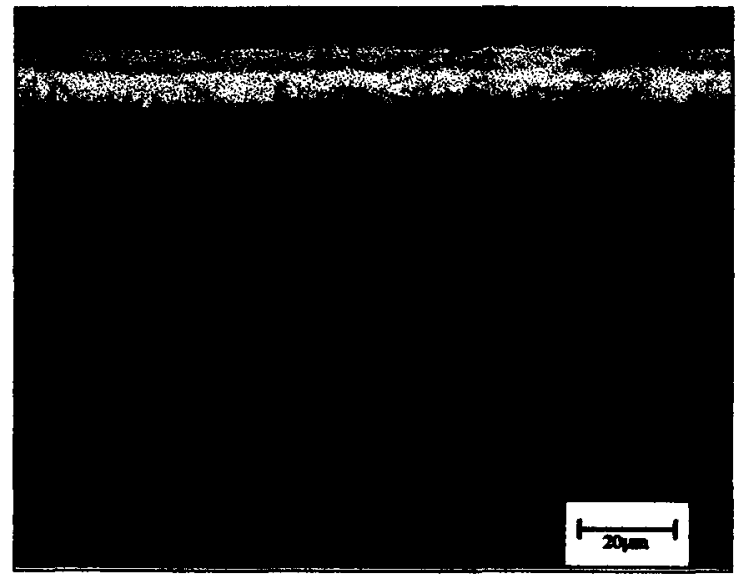

(b) $450^{\circ} \mathrm{C}$.

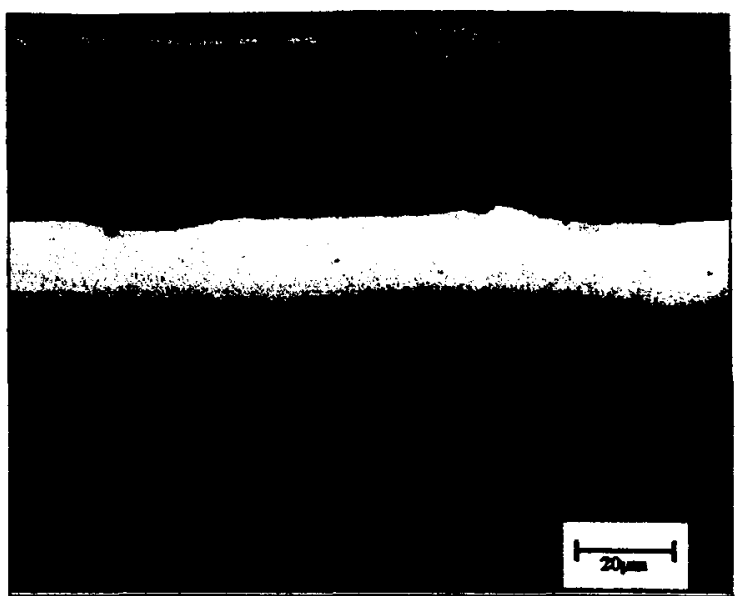

(c) $500^{\circ} \mathrm{C}$.

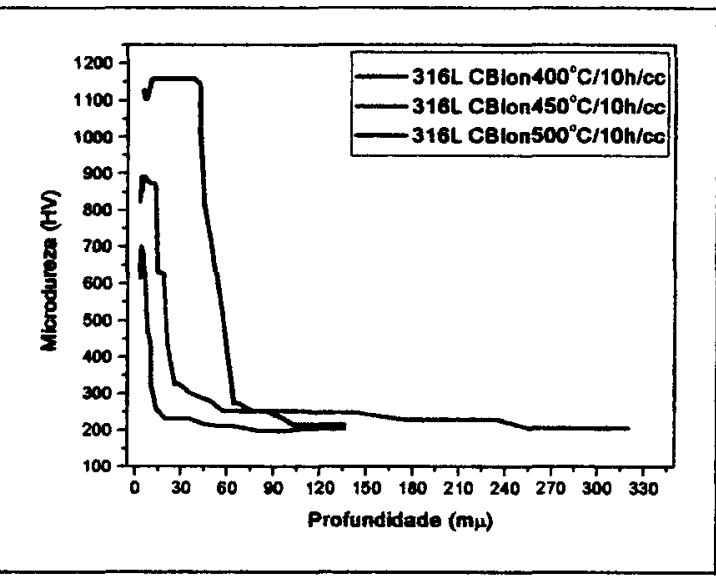

(d) Microdureza.

Figura 15 - Micrografias óticas e curvas de microdurezas para o aço AISI $316 \mathrm{~L}$ carbonitretado a diferentes temperaturas.

Na figura 15(b), observa-se o início da formação da fase escura sobre a fase "S", representado pelos pontos escuros detectados sobre a camada branca. $\mathrm{Na}$ figura 15(c) observa-se a presença da fase $S$ clara sobre o substrato e acima da mesma a fase escura constituída de nitretos e/ou carbonitretos de grande espessura devido à alta taxa de difusão dos elementos formadores de nitretos e carbonitretos tais como, nitrogênio, carbono e cromo. 
Nos perfis de microdurezas apresentados na figura 15(d), observa-se um aumento na dureza e na espessura da camada obtida com o aumento das temperaturas de tratamento.

As camadas carbonitretadas obtidas por plasma nas temperaturas de 400 , 450 e $500^{\circ} \mathrm{C}$ no aço super duplex são mostradas nas figuras de 16 (a), (b) e (c).

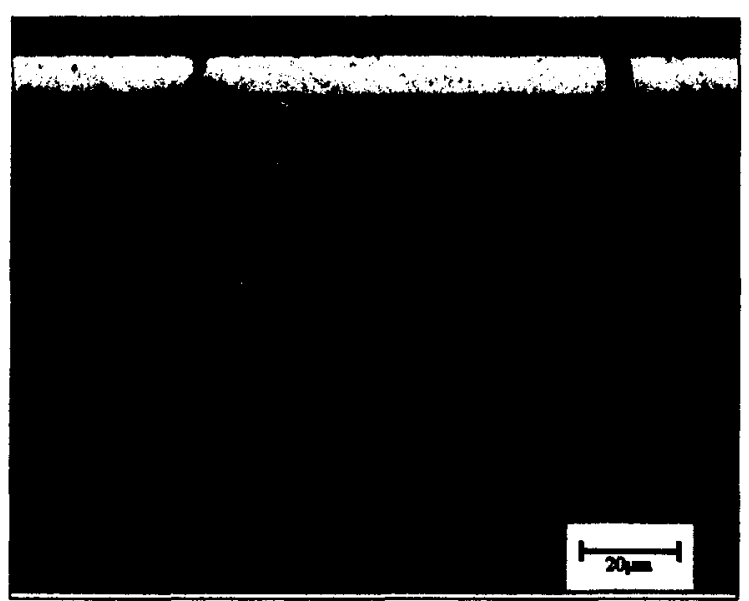

(a) $400^{\circ} \mathrm{C}$.

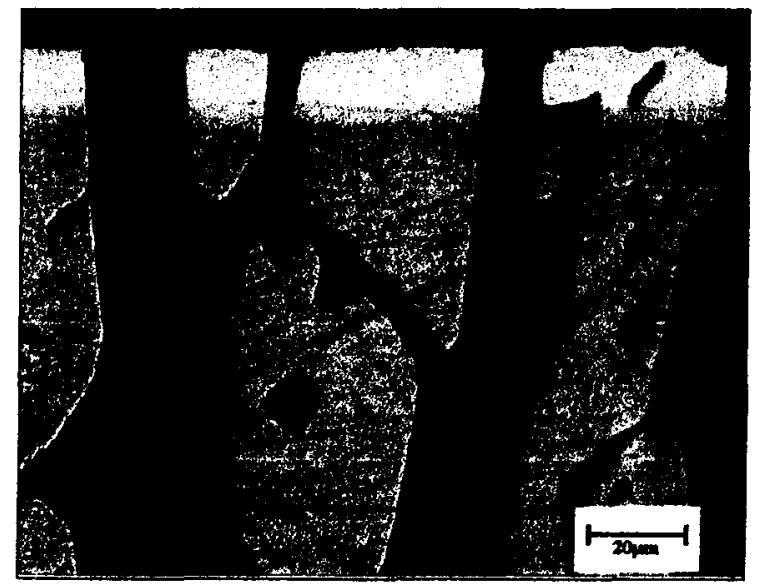

(b) $450^{\circ} \mathrm{C}$.

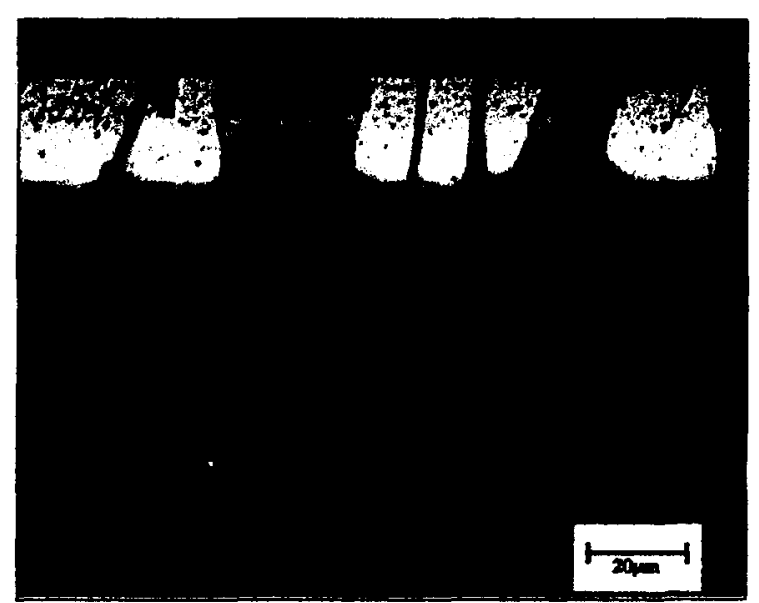

(c) $500^{\circ} \mathrm{C}$.

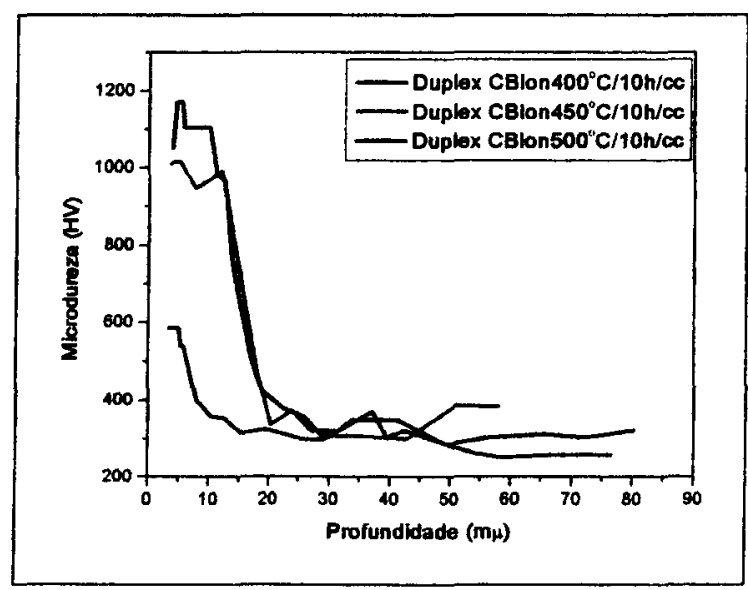

(d) Microdureza.

Figura 16 - Micrografias óticas e curvas de microdurezas para o aço super duplex ASTM A890 Gr 5A carbonitretado a diferentes temperaturas.

Observa-se nas micrografias que as camadas formadas sobre a fase austenítica năo sofreram ataque químico. Isto ocorre devido ao maior teor de níquel 
na fase gama que a estabiliza, dificultando a formação de nitretos e carbonitretos, enquanto que as camadas formadas na ferrita sofreram um ataque intenso, demonstrando a sua menor resistência à corrosão, devida provavelmente à formação de nitretos e carbonitretos de cromo, como pode ser verificado pela diferença de coloração na camada.

Verifica-se na figura $16(d)$ que com o aumento da temperatura de tratamento ocorreu um grande aumento nas durezas das amostras tratadas em temperaturas mais altas devido provavelmente à maior saturação da austenita com nitrogênio e/ou carbono e à formação de nitretos e carbonitretos de cromo. Observou-se que a espessura das camadas obtidas nos tratamentos a $500^{\circ} \mathrm{C}$ foi maior que aquelas obtidas a 400 e $450^{\circ} \mathrm{C}$, fato este devido à decomposição da austenita expandida e formação de nitretos e carbonitretos.

As figuras 17(a), (b) e (c) mostram as micrografias óticas e na figura 17(d) as medidas de microdurezas do aço AISI 409 carbonitretado nas temperaturas de 400,450 e $500^{\circ} \mathrm{C}$ durante 10 horas.

Observa-se um substrato ferrítico e sobre o mesmo a presença de uma fina camada de compostos e abaixo dela uma camada de difusão escura que cresce com o aumento da temperatura.

Na figura 17(d) verifica-se que o tratamento de carbonitretação por plasma, para o caso do aço ferrítico, aumentou significativamente as durezas superficiais das amostras, porém, não foi tão eficiente quanto o tratamento de nitretação por plasma realizados nas mesmas temperaturas. 


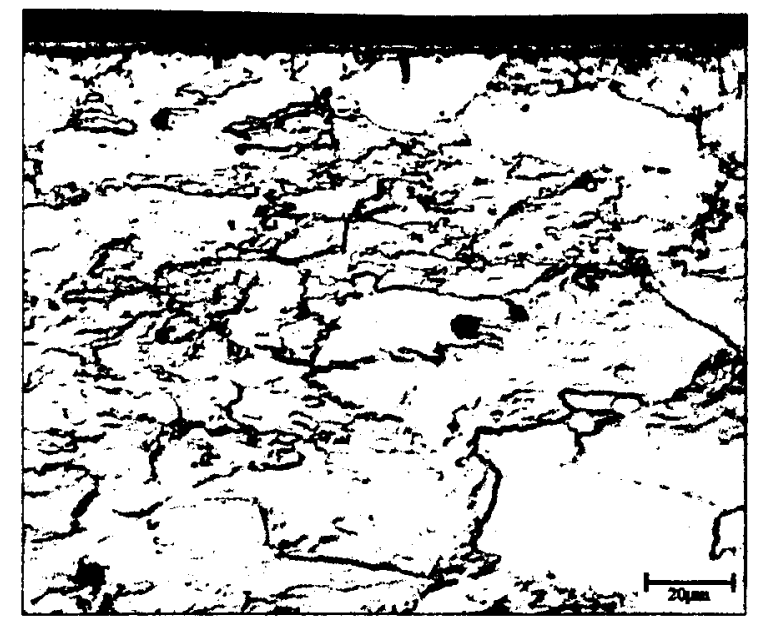

(a) $400^{\circ} \mathrm{C}$.

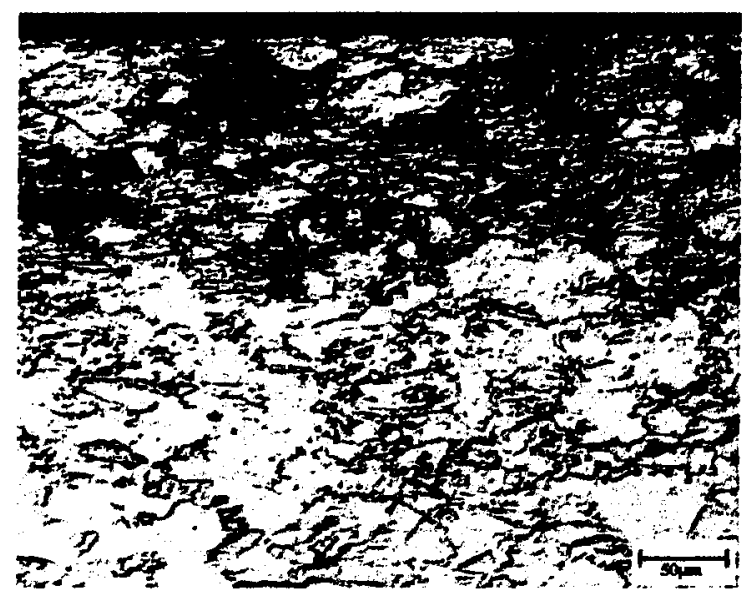

(b) $450^{\circ} \mathrm{C}$.

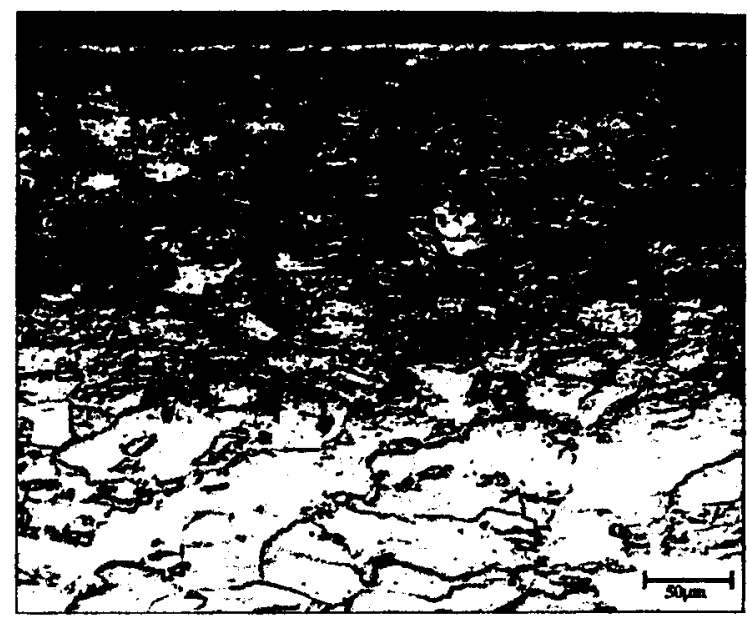

(c) $500^{\circ} \mathrm{C}$.

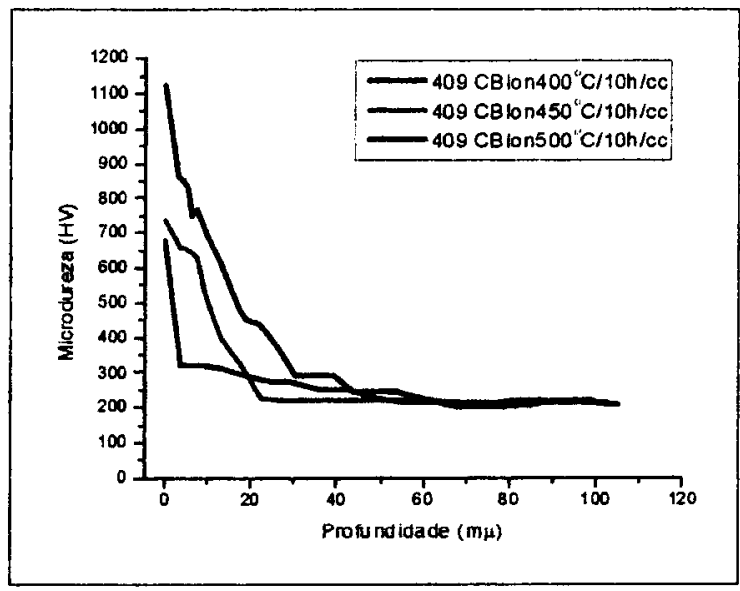

(d). microdureza.

Figura 17 - Micrografias óticas e curvas de microdurezas para o aço AISI 409 carbonitretado a diferentes temperaturas.

$\mathrm{Na}$ tabela 06 são apresentados os resultados gerais dos ensaios de microdurezas realizados nos topos das amostras nitretadas e carbonitretadas nas temperaturas de 400,450 e $500^{\circ} \mathrm{C}$.

Verifica-se em todos os casos um aumento nas durezas e espessuras das camadas nitretadas ou carbonitretadas com o aumento das temperaturas de tratamento, fato este devido ao caráter de ativação térmica do processo. $\mathrm{Na}$ superficie, a concentração de nitrogênio ou carbono é maior do que a solubilidade 
máxima dos mesmos no ferro cfc $(\mathrm{Fe}-\gamma)$ que é de $8,7 \%$ e $1,8 \%$ respectivamente. Aumentando a temperatura, aumenta-se a concentração e profundidade de penetração de nitrogênio e carbono da superfície para o núcleo do substrato, Thaiwatthana et al. (2002). As maiores durezas e profundidades de camadas foram obtidas no caso do aço inoxidável ferrítico nitretado, devido a mais rápida difusão do nitrogênio na ferrita, o que favorece $o$ acúmulo desse elemento superficialmente facilitando a formação de nitretos com durezas elevadas.

Tabela 06-Medidas dos valores de microdureza para os materiais ensaiados.

\begin{tabular}{|c|c|c|c|c|c|c|c|}
\hline $\begin{array}{c}\text { Materi } \\
\text { ais }\end{array}$ & $\begin{array}{l}\mathrm{T}\left({ }^{\circ} \mathrm{C}\right) \\
\text { Carb. }\end{array}$ & & $\begin{array}{c}t(h) \\
\text { Nit. } \theta \text { Carb. }\end{array}$ & $\begin{array}{l}\text { Microdur } \\
\text { eza/Topo } \\
\text { (HV) }\end{array}$ & $\begin{array}{c}\text { Espes } J \\
\text { camada } \\
(\mu \mathrm{m})\end{array}$ & $\begin{array}{c}\text { Microdure } \\
\text { za/Substra } \\
\text { to (HV) }\end{array}$ & $\begin{array}{c}\text { Relaça } \\
\text { Topol } \\
\text { Substrato }\end{array}$ \\
\hline \multicolumn{8}{|l|}{$\begin{array}{l}\text { AISI } 316 \\
\text { AISI } 316 \\
\text { AISI } 316\end{array}$} \\
\hline AISI 316 & 400 & - & 10 & 600 & 12 & 171 & 3,5 \\
\hline AISI 316 & 450 & - & 10 & 1000 & 21 & 177 & 5,6 \\
\hline \multirow[t]{4}{*}{ AISI 316} & 500 & $=$ & 10 & 1200 & 65 & 170 & 7,0 \\
\hline & 400 & & 10 & 700 & 19 & 185 & 3,8 \\
\hline & 450 & & 10 & 750 & 31 & 185 & 4,0 \\
\hline & 500 & & 10 & 1150 & 55 & 180 & 6,4 \\
\hline \multicolumn{8}{|l|}{$\frac{\text { S.duphex }}{\text { S.dun }}$} \\
\hline \multicolumn{8}{|l|}{ S.duplox } \\
\hline S.duplex & 400 & - & 10 & 700 & 11 & 281 & 2,5 \\
\hline S.duplox & 450 & - & 10 & 900 & 20 & 301 & 3,0 \\
\hline S.duplex & 500 & - & 10 & 1150 & 28 & 253 & 4,5 \\
\hline
\end{tabular}

Utilizou-se carga de $25 \mathrm{~g}$.

As diferentes velocidades de difusão do nitrogênio e do carbono são devidas às diferentes energias de ligação desses elementos. Cromo e nitrogênio têm grande afinidade eletrônica e ligam-se facilmente, enquanto que 0 carbono pode difundir livremente através da camada, Thaiwatthana et al. (2002). Trabalhos 
realizados com o uso da técnica GDOS (glow discharge optical spectroscopy) indicam a presença de uma frente com concentração de carbono mais elevada abaixo da camada de nitretos após tratamentos de nitretação e cementação simultâneos nas mesmas condições, Tsujikawa et al (2004).

\section{2 - MICROSCOPIA ELETRÔNICA DE VARREDURA E MICROANÁLISES POR EDX.}

\subsection{1 - Amostras Nitretadas.}

Nas figuras 18, 19 e 20 são apresentados os resultados da varredura em linha por EDX, dos elementos nitrogênio, cromo e ferro nas amostras do aço AISI $316 \mathrm{~L}$ nitretado nas temperaturas de 500,450 e $400^{\circ} \mathrm{C}$ durante 5 horas. Verifica-se no caso da amostra nitretada a $500^{\circ} \mathrm{C}$ que as intensidades das linhas do nitrogênio e do cromo na parte mais superficial e nas fases escuras da camada são mais elevadas, enquanto que a do ferro é mais baixa, comprovando os resultados obtidos nas análises de raios X (figura 32(d)) e perfis de microdureza (figura 11(d)). Tal fato deve-se à presença de nitretos de cromo (fase escura da camada) e à alta saturação de nitrogênio na fase "S". 


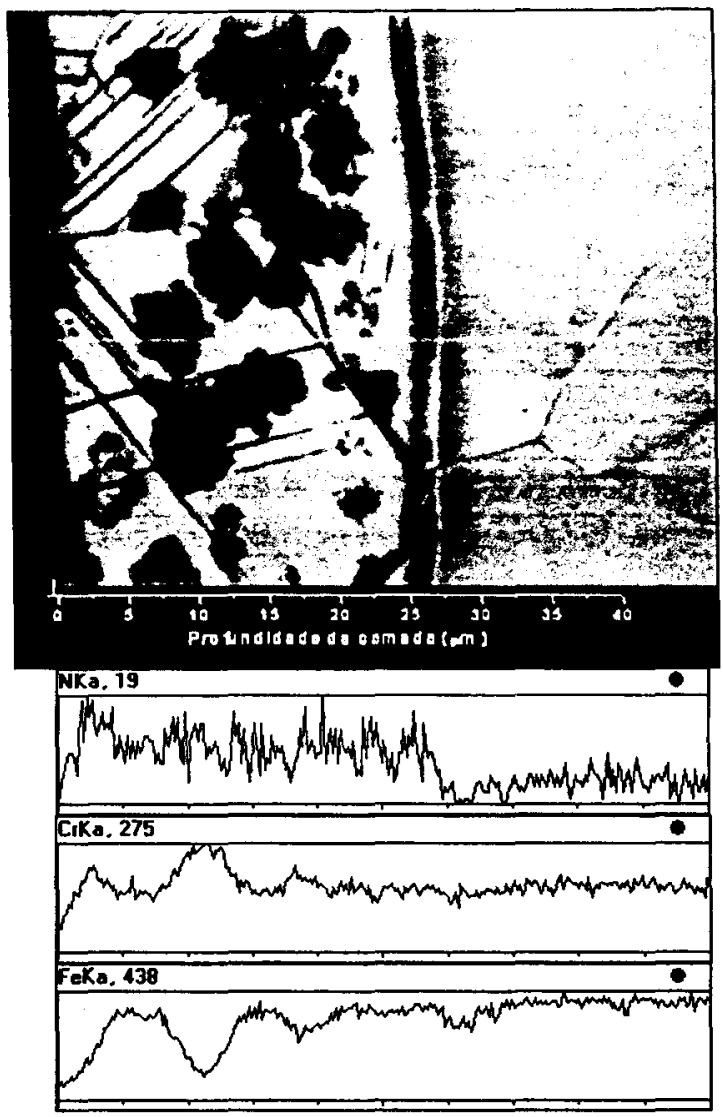

Figura 18 - Varredura em linha do aço AISI $316 \mathrm{~L}$ nitretado a $500^{\circ} \mathrm{C}$.

As linhas obtidas para a amostra tratada a $450^{\circ} \mathrm{C}$ (figura 18), indicam uma maior concentração de nitrogênio na camada e baixos teores de ferro e cromo que aumentam gradualmente até se estabilizarem no substrato, substituindo 0 nitrogênio, indicando a presença da austenita expandida ou fase " $S$ ", conforme os resultados das análises de raios $X$ mostrados na figura 32(c). 


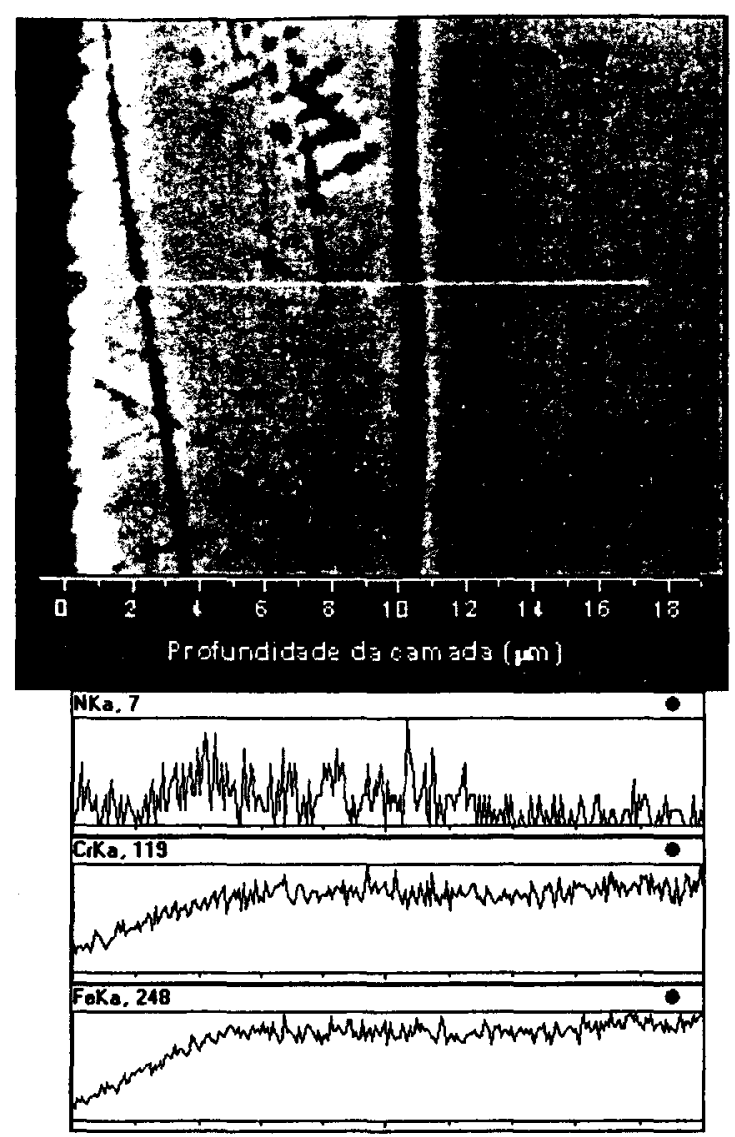

Figura 19 - Varredura em linha do aço AISI $316 \mathrm{~L}$ nitretado a $450^{\circ} \mathrm{C}$.

Os resultados das microanálises para a amostra nitretada a $400^{\circ} \mathrm{C}$ são mostrados nas figuras 20 . O comportamento foi semelhante ao apresentado pela amostra tratada a $450^{\circ} \mathrm{C}$. 


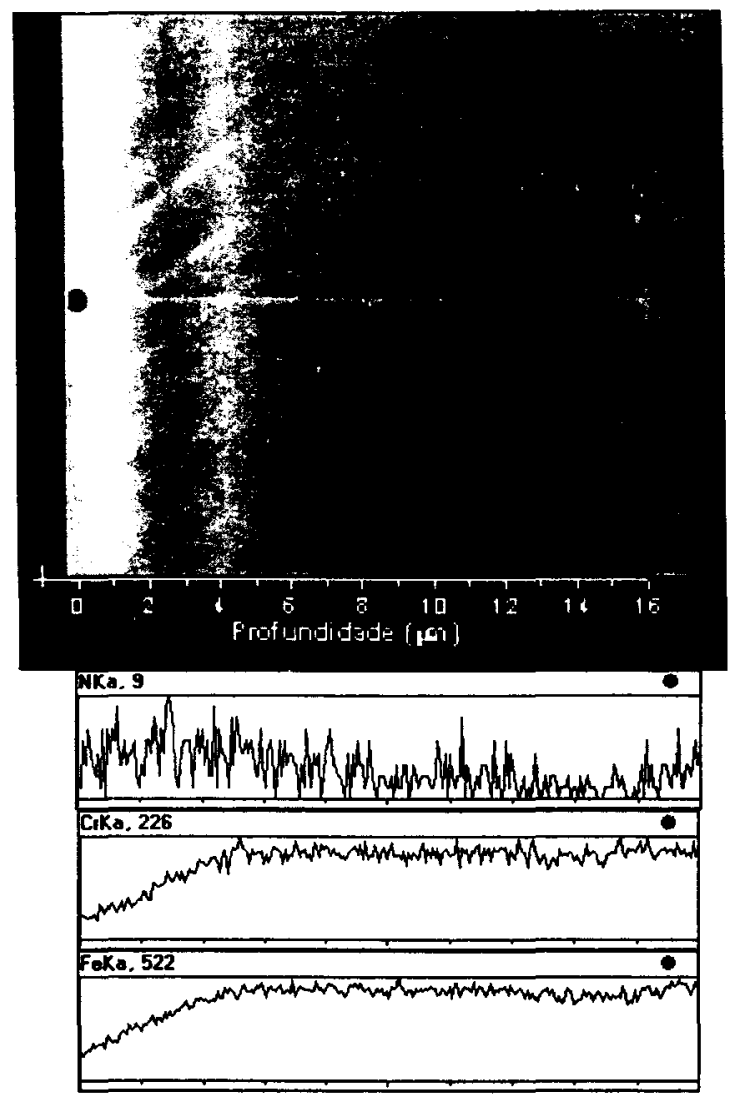

Figura 20 - Varredura em linha do aço AISI $316 \mathrm{~L}$ nitretado a $400^{\circ} \mathrm{C}$.

A figura 21 mostra os resultados da varredura em linha por EDX dos elementos nitrogênio, cromo e ferro, da amostra do aço AISI 409 nitretado na temperatura de $500^{\circ} \mathrm{C}$. Verifica-se na superfície da camada a presença de uma fase clara, constituída provavelmente de ferrita expandida. A varredura em linha indica na região dessa fase um teor de nitrogênio superior ao do substrato, um teor de cromo igual ao do substrato e elevado teor de ferro, o que leva a crer na existência da ferrita expandida.

No restante da camada, verifica-se os altos teores de nitrogênio e cromo presentes, indicando a presença de nitretos de cromo. 


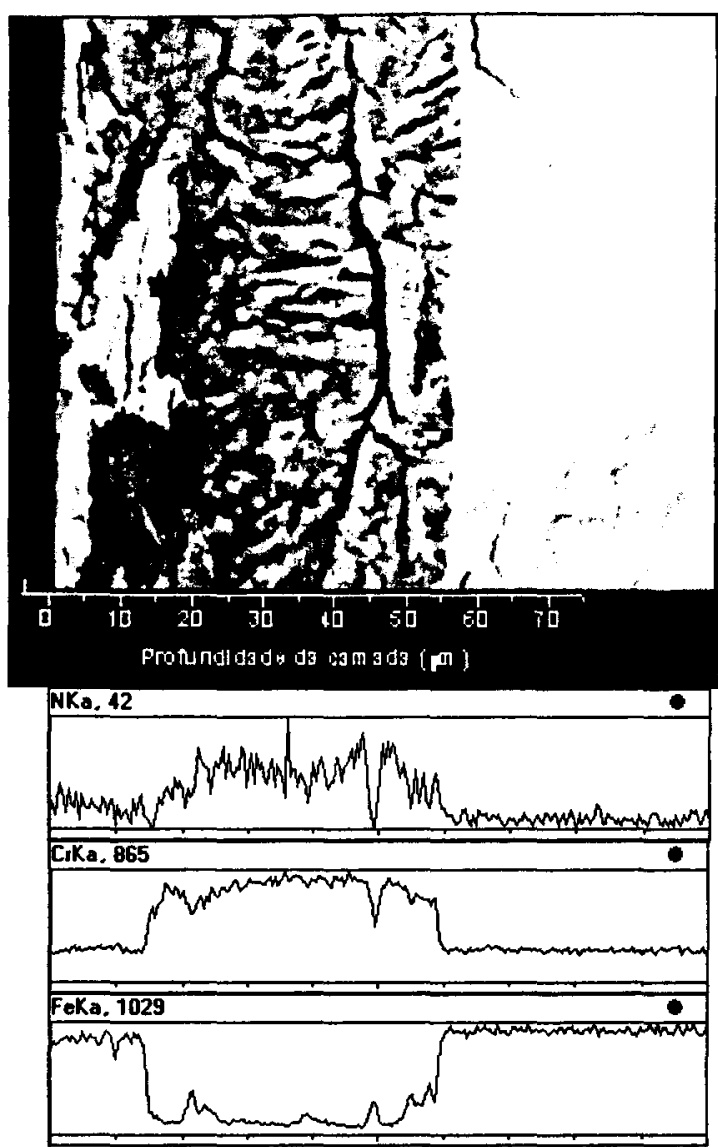

Figura 21 - Varredura em linha do aço AISI 409 nitretado a 500ํ․

$\mathrm{Na}$ figura 22 são apresentados os resultados da varredura em linha por EDX, dos elementos nitrogênio, cromo e ferro, no aço super duplex ASTM A890 Gr5A nitretado na temperatura de $500^{\circ} \mathrm{C}$. Verifica-se a alta concentração de nitrogênio da camada, com diminuição gradativa até a interface camada/substrato. Observa-se que a concentração de nitrogênio e do cromo é superior à do ferro, devido à formação de nitretos de cromo e de ferro e da supersaturação da camada pelo nitrogênio e formação da ferrita expandida, conforme resultados mostrados na análise por raios $\mathrm{X}$ (figura $34(\mathrm{~d})$ ). 


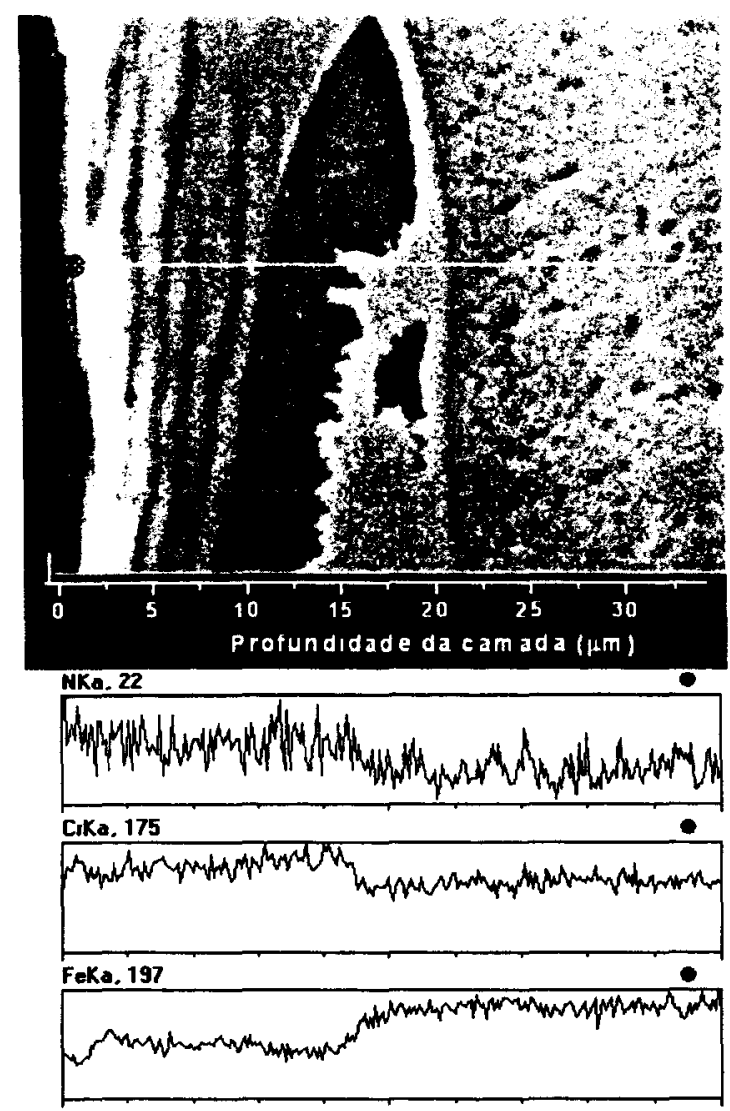

Figura 22 - Varredura em linha do aço super duplex ASTM A890 Gr5A nitretado a $500^{\circ} \mathrm{C}$.

A figura 23 mostra a camada monofásica fina produzida a $450^{\circ} \mathrm{C}$, com alta concentração de nitrogênio na sua parte mais externa. Na análise da varredura em linha, observa-se que as concentrações dos elementos $\mathrm{Fe}$ e $\mathrm{Cr}$ apresentaram mudanças significativas a partir de $2 \mu \mathrm{m}$ de profundidade indicando a presença de uma camada superficial decorrente da supersaturação do substrato austenoferrítico pelo nitrogênio e formação das fases ferrita ou austenita expandidas ou fases "S". 


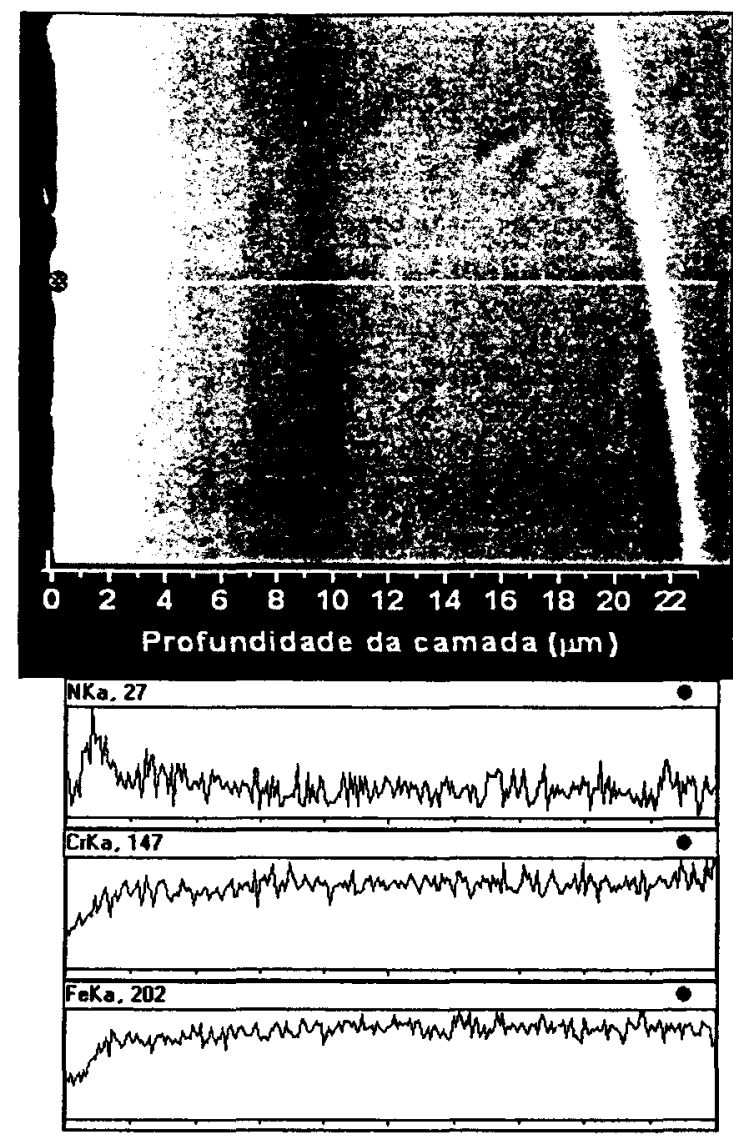

Figura 23 - Varredura em linha do aço super duplex ASTM A890 Gr5A nitretado a $450^{\circ} \mathrm{C}$.

\subsection{2 - Amostras Carbonitretadas}

A figura 24 apresenta a micrografia do aço inoxidável super duplex ASTM A890 Gr5A carbonitretado na temperatura de $500^{\circ} \mathrm{C}$ durante 10 horas. Observa-se a presença do substrato austeno-ferrítico e sobre o mesmo a camada carbonitretada. 
Verifica-se em ambos os casos a presença de carbono e nitrogênio em teores mais elevados nas regiões superficiais das camadas e o seu rápido decréscimo posterior devido à difusão competitiva entre o nitrogênio e o carbono.

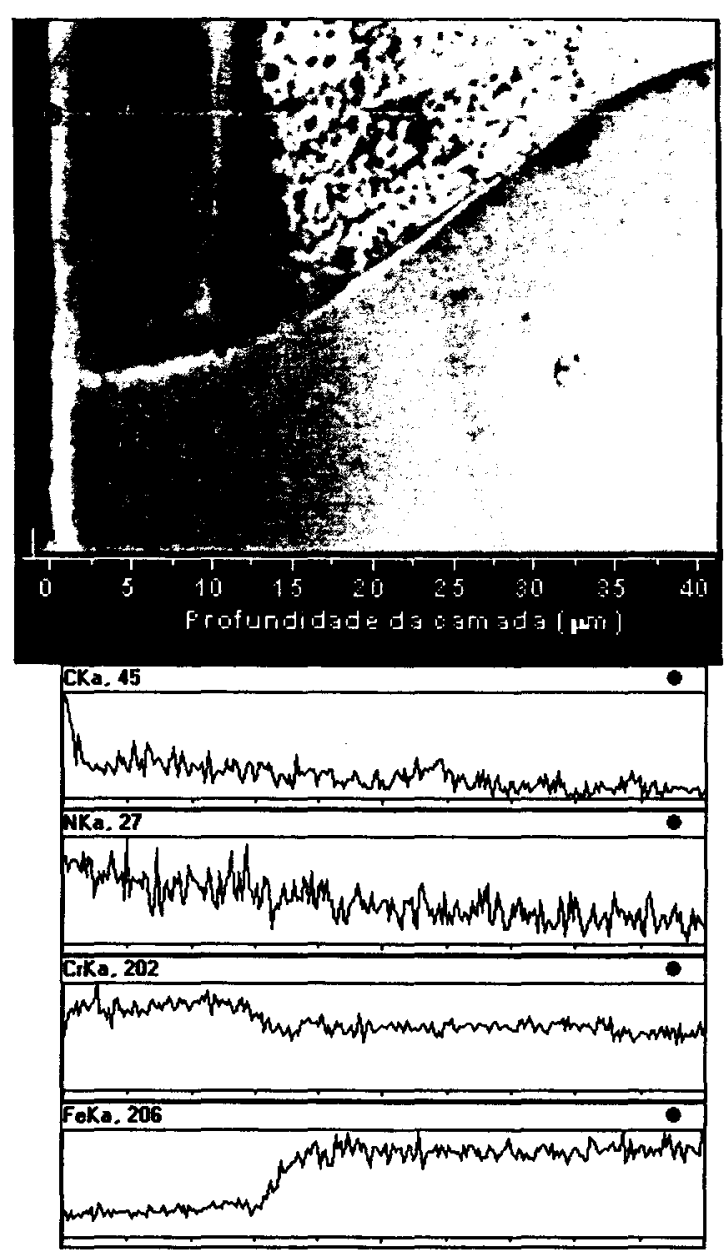

Figura 24 - Varredura em linha do aço super duplex ASTM A890 Gr5A carbonitretado a $500^{\circ} \mathrm{C}$. 


\section{3 - ENSAIO DE DESGASTE}

\subsection{1 - Amostras Nitretadas.}

Nas figuras 25 a 27 são mostrados os resultados dos ensaios de desgaste das amostras nitretadas dos aços AISI 316L, AISI 409 e super duplex ASTM A890 Gr5A e as respectivas calotas produzidas nos ensaios que tiveram duração de 20 minutos. Em todos os casos ocorreu um aumento significativo da resistência ao desgaste em relação às amostras não nitretadas, comprovando a eficácia dos tratamentos quanto a essa propriedade.

No caso das amostras do aço inoxidável austenítico AISI 316L (figura 25(a)), o melhor desempenho foi apresentado pela amostra tratada a $500^{\circ} \mathrm{C}$, constituída basicamente de nitretos de cromo (figura $32(\mathrm{~d})$ ). A amostra tratada a $400^{\circ} \mathrm{C}$, cuja camada constitui-se basicamente de austenita expandida apresentou também comportamento semelhante ao desgaste até uma distância percorrida de 120 metros, que corresponde a uma profundidade de camada de $9 \mu \mathrm{m}$ (ver tabela 07). A partir daí o desgaste acelerou-se devido ao final da camada e início do substrato de menor dureza.

$\mathrm{Na}$ camada obtida a $450^{\circ} \mathrm{C}$, constituída principalmente de austenita expandida, observa-se que ocorreu um aumento na taxa de desgaste, provavelmente devido à decomposição da mesma que ocorre a partir desta temperatura e que pode ter contribuido para a menor resistência ao desgaste da camada. 


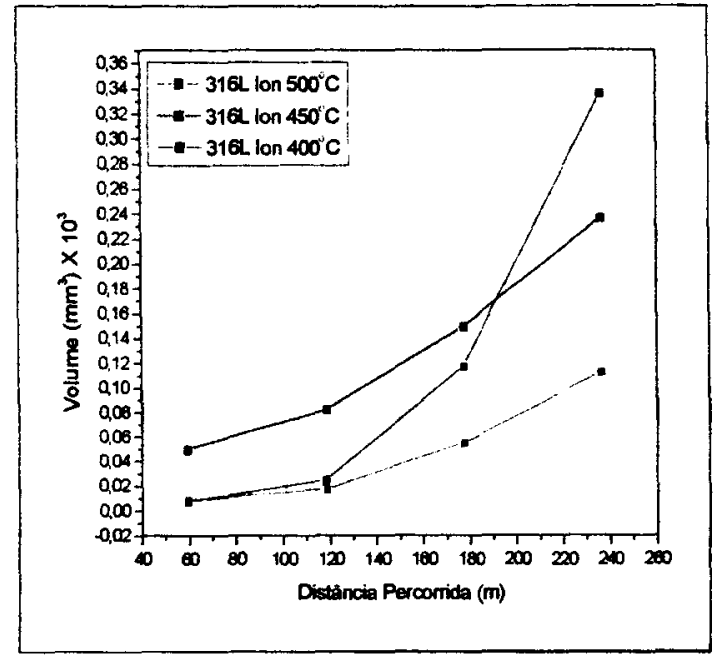

Figura 25a- Perda de massa em função da distância percorrida.

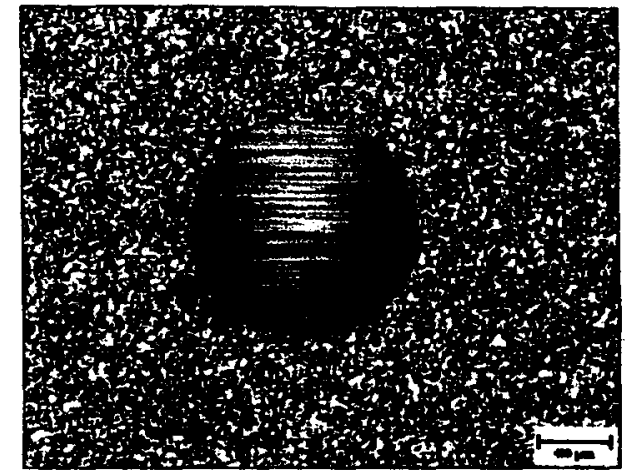

Figura 25b- Calota obtida na amostra $316 \mathrm{~L}$ Nit. $500^{\circ} \mathrm{C} / 20 \mathrm{~min}$.

As camadas produzidas no aço inoxidável ferrítico AISI 409 apresentaram aumento crescente das resistências ao desgaste com o aumento da temperatura de tratamento (figura 26(a)). O aumento acentuado no desgaste da camada obtida a $400^{\circ} \mathrm{C}$ deveu-se ao rompimento da camada e o alcance do substrato.

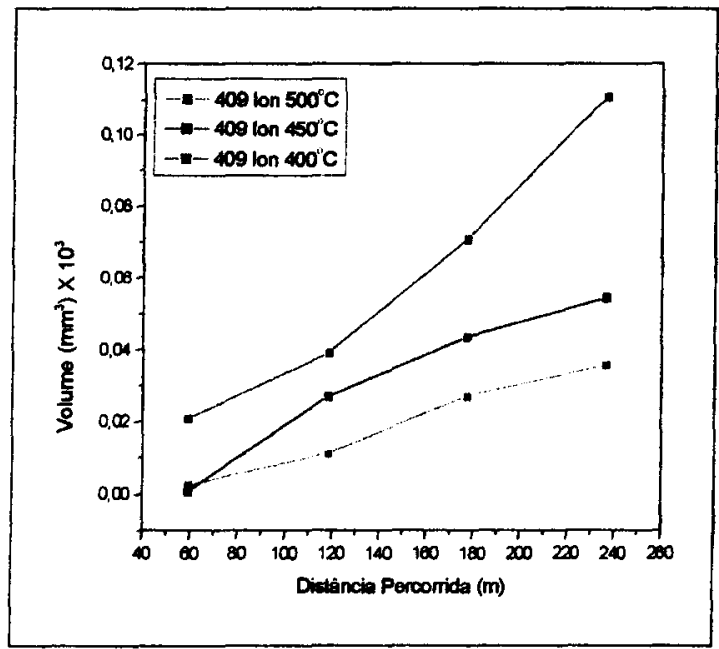

Figura 26a Perda de massa em função da distância percorrida.

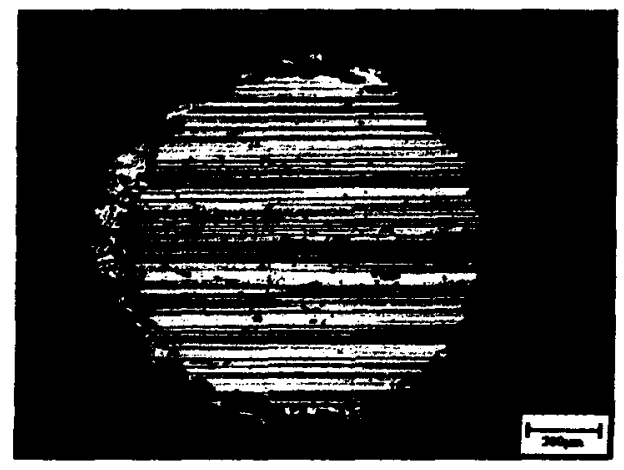

Figura 26b-Calota obtida no Aço AISI 409 Nit. $500^{\circ} \mathrm{C} / 20$ minutos. 
Na figura 27(a) são apresentados os resultados das perdas volumétricas das amostras tratadas com temperaturas variáveis. Verifica-se que a resistência ao desgaste cresceu com o aumento da temperatura de nitretação.

No caso da amostra tratada a $400^{\circ} \mathrm{C}$, a mudança abrupta no padrão de desgaste deveu-se ao rompimento da camada, que apresenta uma pequena espessura de $8 \mu \mathrm{m}$ (tabela 07).

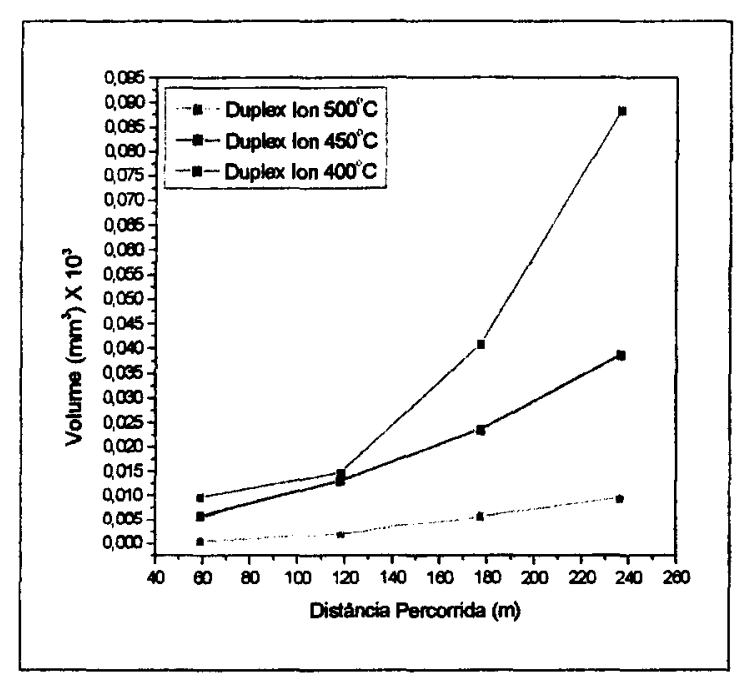

Figura 27a-Perda de massa em funçăo da distância percorrida.

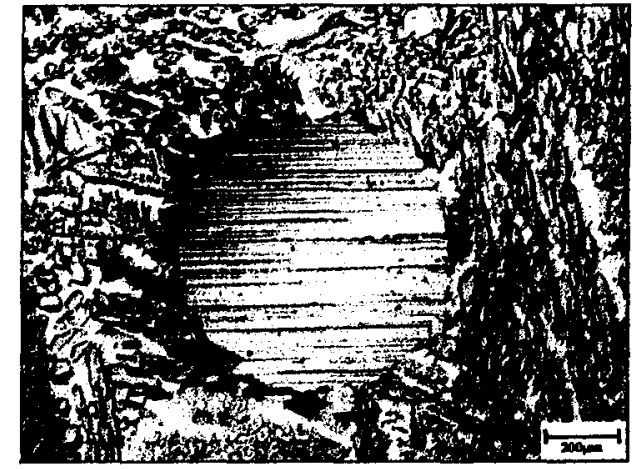

Figura 27b- Calota obtida no Aço super duplex ASTM A890 Gr 5A Nit. $500^{\circ} \mathrm{C} / 20 \mathrm{~min}$.

\subsection{2 - Amostras Carbonitretadas.}

Nas figuras 28(a), 29(a) e 30(a) são apresentados os resultados dos ensaios de desgaste das amostras carbonitretadas dos aços inoxidáveis austenítico AISI 316L, ferrítico AISI 409 e super duplex ASTM A890 Gr5A nas temperaturas de 400 , 450 e $500^{\circ} \mathrm{C}$ por 10 horas. 
Em todos os casos ocorreu um aumento da resistência ao desgaste com o aumento da temperatura, uma vez que temperaturas maiores de tratamento proporcionam a formação de camadas mais espessas e com maiores durezas.

A resistência ao desgaste das camadas carbonitretadas se deve à presença da fase " $S$ " ou austenita expandida, com alto teor de nitrogênio e/ou carbono em solução sólida ou a formaçăo dos carbonitretos de cromo, presentes nas camadas obtidas, como pode ser verificado nas difratogramas de raios X (figuras 32 a 34), que săo os responsáveis por esse aumento da resistência ao desgaste das camadas.

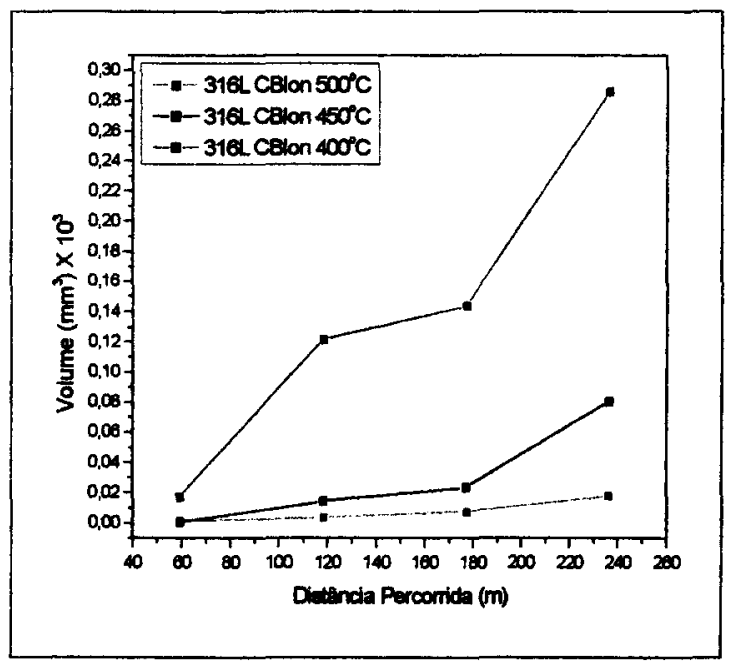

Figura 28a- Perda de massa em funçăo da distância percorrida.

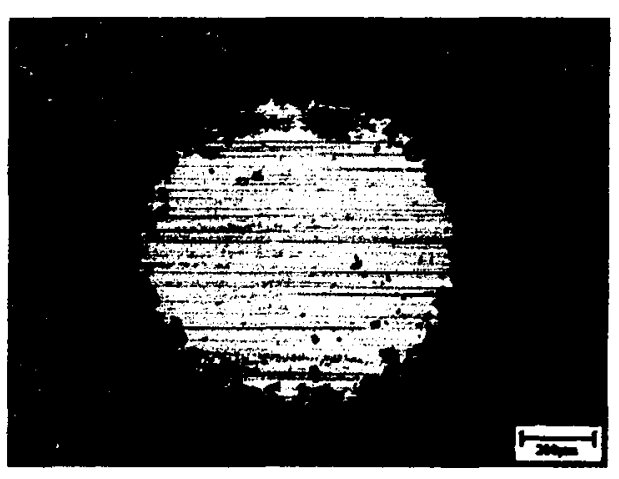

Figura 28b- Calota obtida no Aço AISI $316 \mathrm{~L} \mathrm{Carb.} 500^{\circ} \mathrm{C} / 20 \mathrm{~min}$.

O aumento abrupto do desgaste das amostras tratadas, principalmente em temperaturas mais baixas, deve-se ao rompimento da camada e o conseqüente alcance do substrato de menor dureza. 


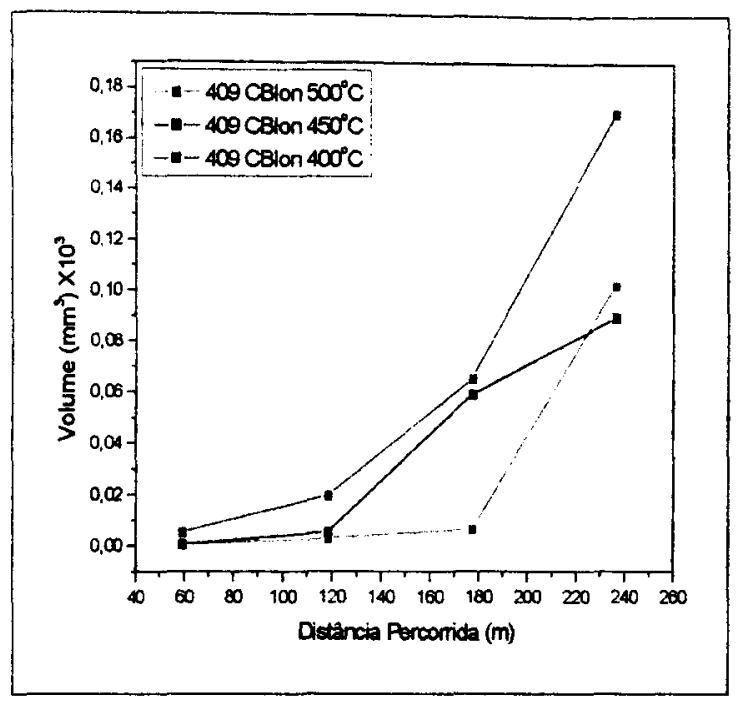

Figura 29a - Perda de massa em funçăo da distância percorrida.

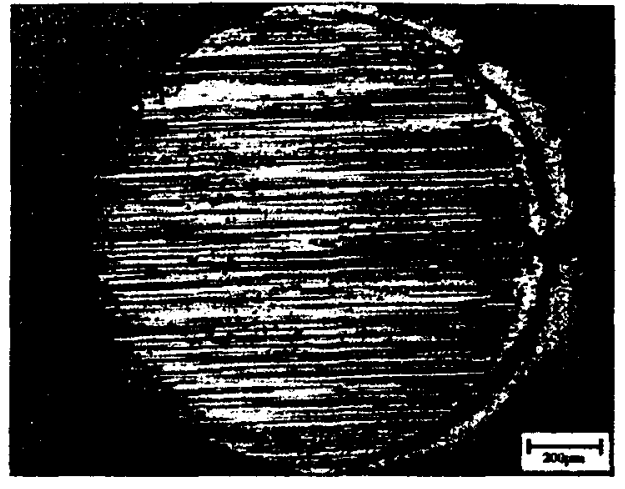

Figura 29b-Calota obtida no Aço AISI 409 Carb. $500^{\circ} \mathrm{C} / 20 \mathrm{~min}$.

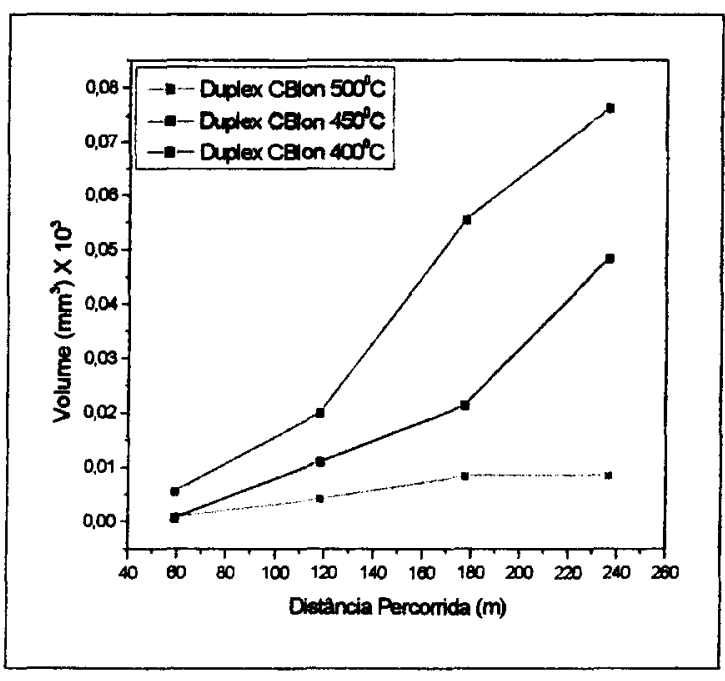

Figura 30a - Perda de massa em função da distância percorrida.

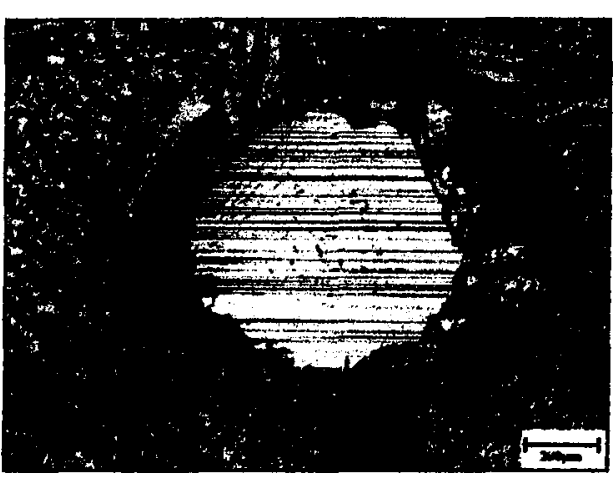

Figura 30b-Calota obtida no Aço Super duplex ASTM A890 Gr 5A Carb. $500^{\circ} \mathrm{C} / 20 \mathrm{~min}$.

Como o ensaio de desgaste microabrasivo foi realizado sem o uso de abrasivos, os sulcos caracteristicos do desgaste do tipo abrasivo foram produzidos 
provavelmente pelas particulas duras destacadas das camadas, e em menor escala da esfera usada no ensaio. Não foi detectado o mecanismo de desgaste adesivo nas calotas obtidas nos materiais ensaiados.

Na tabela 07 são apresentados os resultados dos ensaios de desgaste realizados nas camadas produzidas e nos substratos, obtidos por meio das equações abaixo:

$$
\begin{aligned}
& R^{2}=x^{2}+r_{c} \\
& R=x+h
\end{aligned}
$$

Onde; $R$ e $r_{c}$ são os raios da esfera e da calota respectivamente e $h$ é a profundidade da calota determinada de acordo com figura 31 e registrada na tabela 07 para serem comparados com as profundidades das camadas obtidas e relacionados com a temperatura de tratamento para cada tipo de aço estudado.

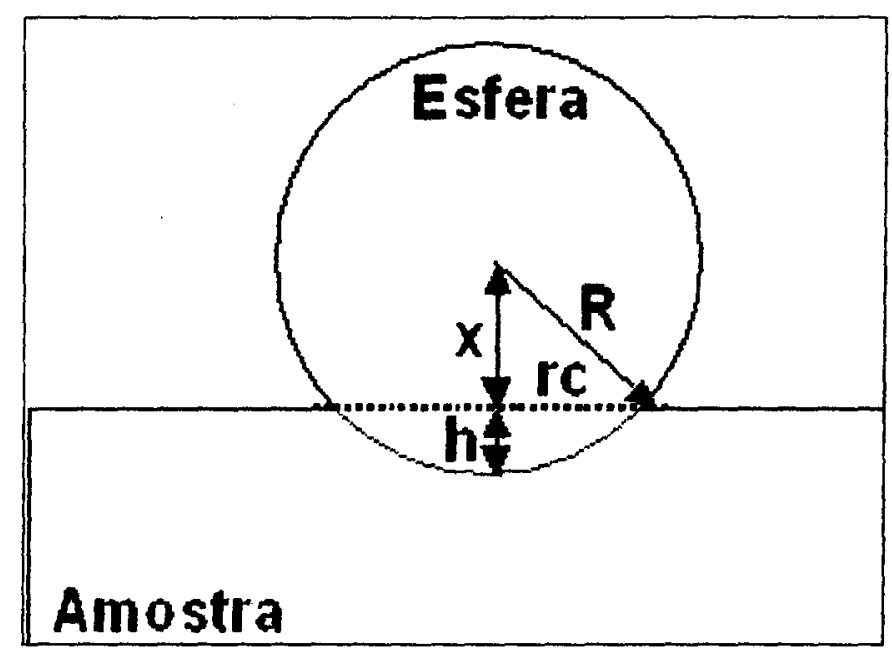

Figura 31- Esquema da produçăo da calota no ensaio de desgaste microabrasivo.

Com a determinaçăo da profundidade da calota obtida determinou-se o volume de desgaste para cada material ensaiado de acordo com a seguinte equação:

$$
V_{c}=\pi h^{2}\left(r_{c}-h / 3\right)
$$


Onde:

$V_{c}$ - volume da calota $\left(\mathrm{mm}^{3}\right) ;$

$\mathrm{h}$ - profundidade da calota $(\mu \mathrm{m})$;

$r_{c}$ - raio da calota $(\mathrm{mm})$

Os tratamentos de nitretação e carbonitretação por plasma foram muito eficientes no aumento da resistência ao desgaste do aço inoxidável austenítico AISI 316L. A supersaturação com nitrogênio e/ou carbono e a formação de nitretos e carbonitretos de cromo e de ferro são os principais fatores responsáveis por esse aumento, juntamente com a grande quantidade de discordâncias e tensões de compressão contidas nas camadas obtidas.

As camadas carbonitretadas apresentaram menor perda de massa durante o ensaio de desgaste que as camadas nitretadas. A resistência de todas as camadas aumentou com o aumento da espessura e da temperatura de tratamento.

No aço inoxidável ferrítico AISI 409, verifica-se que para pequenas distâncias percorridas as camadas carbonitretadas apresentaram menor perda de massa em relação às nitretadas, devido à maior supersaturação do nitrogênio e/ou carbono na superfície da amostra. Contudo, para maiores distâncias percorridas, verifica-se que as camadas obtidas na condição nitretada apresentaram menor perda de massa em relação a carbonitretada, devido à maior difusão de nitrogênio em temperaturas mais elevadas e à grande afinidade química desse elemento pelo cromo, formando os nitretos de cromo, considerando-se que a máxima solubilidade de nitrogênio no substrato ferrítico é de apenas $1,7 \%$.

O mecanismo de desgaste atuante foi o abrasivo, como pode se verificado pelo sulcamento existente nas calotas. Como não se utilizou abrasivo externo, como no caso das amostras nitretadas, partículas destacadas das camadas constituiram-se nos agentes abrasivos. 
Tabela 07- Medidas das profundidades das calotas obtidas por meio dos ensaios de desgaste nas camadas e nos substratos.

\begin{tabular}{|c|c|c|c|c|c|}
\hline \multirow[b]{2}{*}{ AÇO } & \multicolumn{4}{|c|}{ Distancia percorrida (metros) } & \multirow[b]{2}{*}{$\begin{array}{l}\text { Espessura } \\
\text { da Camada } \\
\text { (pm) }\end{array}$} \\
\hline & 59,05 & 118,10 & 177,15 & 236,20 & \\
\hline ASI316L & \multicolumn{4}{|c|}{ Profundidade da calota ( $\mu \mathrm{m})$} & - \\
\hline Substrato & 31,59 & 82,80 & 113,71 & 133,87 & - \\
\hline Nt 6008 & 5,08 & 8,31 & 15,46 & 23,60 & 9 \\
\hline Netare & 10,96 & 13,40 & 17,07 & 20,50 & 13 \\
\hline Nitsore & 5,35 & 7,21 & 11,01 & 15,21 & 28 \\
\hline Carb $.400^{\circ} \mathrm{C}$ & 7,21 & 15,72 & 16,80 & 22,12 & 12 \\
\hline Carb. $450^{\circ} \mathrm{C}$ & 2,0 & 6,64 & 8,12 & 13,34 & 21 \\
\hline Carb. $500^{\circ} \mathrm{C}$ & 2,77 & 3,91 & 5,16 & 7,34 & 65 \\
\hline AISI 409 & - & - & - & - & - \\
\hline Substrato & 10,03 & 12,63 & 28,86 & 37,63 & - \\
\hline Nit. $400^{\circ} \mathrm{C}$ & 7,77 & 9,99 & 12,65 & 15,15 & 16 \\
\hline Nit. $450^{\circ} \mathrm{C}$ & 2,17 & 8,61 & 10,42 & 11,40 & 28 \\
\hline Nit. $500^{\circ} \mathrm{C}$ & 3,34 & 6,06 & 8,60 & 9,62 & 45 \\
\hline Carb. $400^{\circ} \mathrm{C}$ & 4,65 & 7,59 & 12,27 & 17,79 & 19 \\
\hline Carb. $450^{\circ} \mathrm{C}$ & 2,27 & 4,60 & 11,78 & 13,88 & 31 \\
\hline Carb. $500^{\circ} \mathrm{C}$ & 2,08 & 3,57 & 4,94 & 14,63 & 53 \\
\hline Superduplex & - & - & - & - & - \\
\hline Substrato & 20,29 & 22,88 & 27,46 & 30,85 & - \\
\hline Nit. $400^{\circ} \mathrm{C}$ & 5,70 & 6,75 & 10,15 & 13,82 & 4 \\
\hline Nit. $450^{\circ} \mathrm{C}$ & 4,67 & 6,45 & 8,14 & 9,92 & 10 \\
\hline Nit. $500^{\circ} \mathrm{C}$ & 1,76 & 3,03 & 4,63 & 5,66 & 21 \\
\hline Carb. $400^{\circ} \mathrm{C}$ & 4,60 & 7,64 & 11,48 & 13,04 & 11 \\
\hline Carb. $450^{\circ} \mathrm{C}$ & 2,07 & 6,02 & 7,84 & 10,87 & 20 \\
\hline Carb. $500^{\circ} \mathrm{C}$ & 2,02 & 4,12 & 5,41 & 5,43 & 28 \\
\hline
\end{tabular}




\section{4 - ANÁLISES POR DIFRAÇÃO DE RAIOS-X.}

\subsection{1 - Amostras Nitretadas.}

Nas figuras 32 a 34 são mostrados os difratogramas referentes ao substrato e às camadas nitretadas produzidas nos aços inoxidáveis AISI 316L, super duplex ASTM A890 Gr5A e AISI 409 respectivamente.

A figura 32(a) referente ao substrato do aço AISI 316L, constituído de austenita, indica apenas a presença dos picos da austenita, correspondente à matriz cfc. Nas figuras 32 (b) e (c) referentes às amostras nitretadas nas temperaturas de 400 e $450^{\circ} \mathrm{C}$ verifica-se a presença dos picos padrões de difração da austenita do substrato e os picos característicos da austenita expandida ou fase "S", que são os picos $\gamma_{N}(111)$ e $\gamma_{N}(200)$ com ângulos de difração $(2 \theta)$ deslocados para a esquerda e mais largos que os picos padrões. Este alargamento dos picos é uma característica desta fase devido à supersaturação da austenita com o nitrogênio e deformação do parâmetro de rede.

No caso da amostra nitretada a $400^{\circ} \mathrm{C}$, devido à pequena espessura da camada, verifica-se também a presença dos picos do substrato da austenita. $\mathrm{Na}$ figura $32(\mathrm{~d})$ referente à amostra tratada a $500^{\circ} \mathrm{C}$ ocorre a presença da austenita expandida e nitretos de cromo. Os nitretos de cromo formados constituem-se na fase escura presentes na fotomicrografia da figura 11(c), uma vez que em temperaturas mais elevadas de tratamentos ocorrem condições mais favoráveis para a difusão do cromo, o que permite a formação de nitretos. 


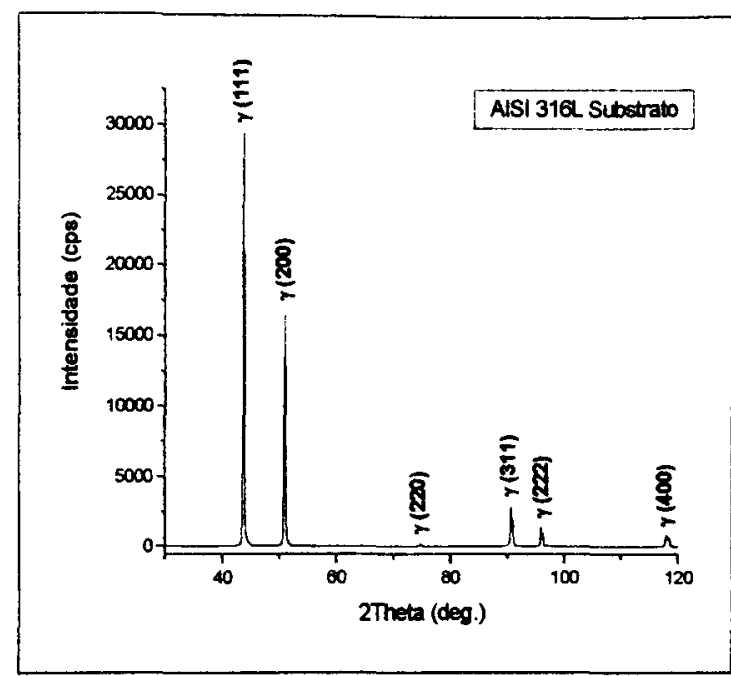

(a)

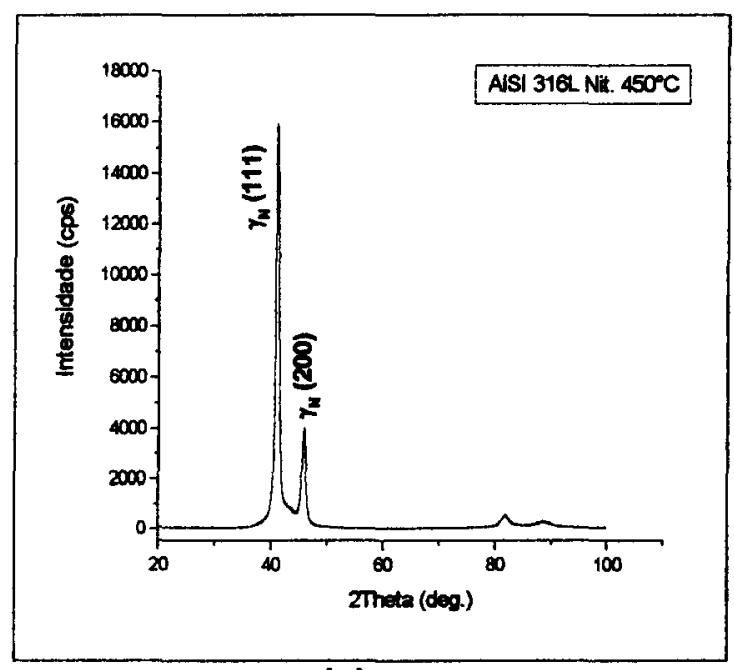

(c)

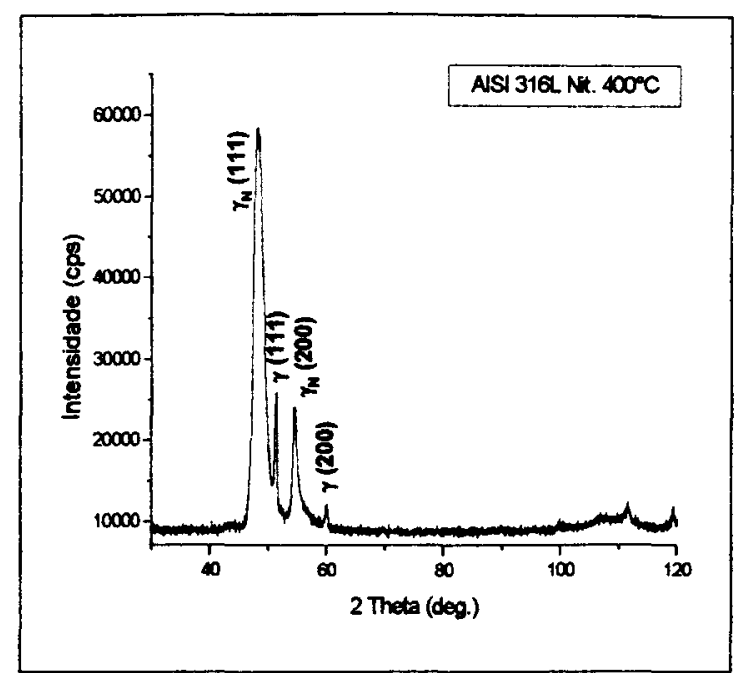

(b)

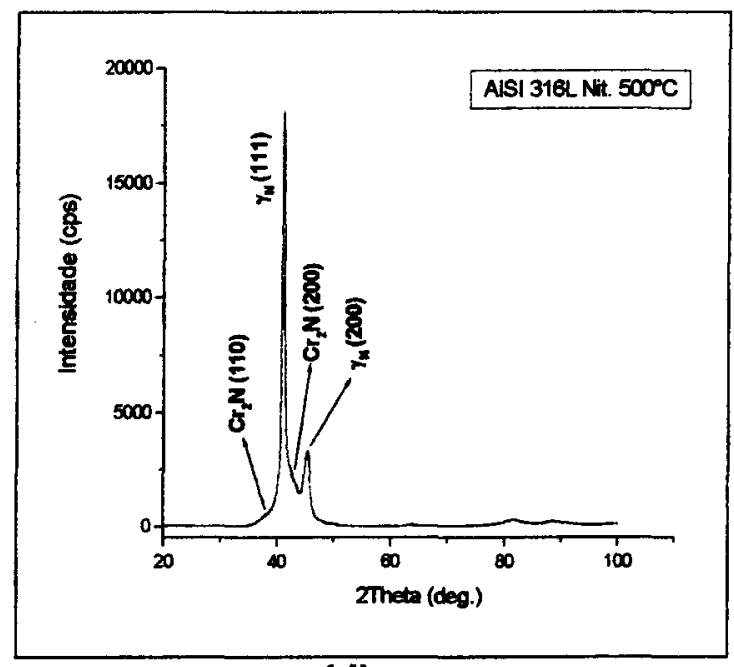

(d)

Figura 32- Difratogramas de raios $X$ das amostras do aço AISI 316L: (a) substrato; (b) Nit. $400^{\circ} \mathrm{C}$, (c) Nit. $450^{\circ} \mathrm{C}$ e (d) Nit. $500^{\circ} \mathrm{C}$ durante 5 horas.

De acordo com alguns autores a fase "S" pode também ser uma solução sólida metaestável, supersaturada com nitrogênio com uma estrutura cúbica de face centrada (cfc) desordenada, uma vez que as posições dos picos de difração de raios $\mathrm{X}$ da fase " $\mathrm{S}$ " desviam-se das posições ideais de um reticulado cúbico de face centrada (cfc) austenítico, Bell (2002); Dearnley (2002) e Li et al. (2002). O desenvolvimento de altas tensões residuais compressivas na camada nitretada 
obtida em baixas temperaturas pode também ser responsável pelo deslocamento dos picos de difração das posições ideais do reticulado cúbico de faces centradas (cfc), Sun et al. (1999).

Alguns pesquisadores, Cheng et al. (2004), também sugerem que as camadas nitretadas obtidas a temperaturas baixas apresentam a uma estrutura tetragonal de corpo centrado (tcc).

$\mathrm{Na}$ figura 33 são apresentados os padrões de difração de raios-X do substrato do aço super duplex ASTM A890 Gr5A e das camadas nitretadas obtidas por plasma durante 5 horas nas temperaturas de 400,450 e $500^{\circ} \mathrm{C}$.

$\mathrm{Na}$ figura 33(a), são indicadas as linhas de difração do substrato do aço super duplex ASTM A890 Gr5A indicando apenas a presença fases austenítica e ferrítica características do substrato e, na figura $33(b)$, aparecem linhas de difração referentes à austenita ou ferrita expandidas (fase clara) mostradas na figura 11(a). Novamente, verifica-se o deslocamento dos picos, tanto da austenita como da ferrita para ângulos menores e com alargamento desses picos, o que indica a presença dessas fases.

Nas figuras 33(c) e 33(d), são indicadas as linhas de difração dos nitretos de cromo (ver região escura nas figuras 11 (b) e 11(c)), nitretos de ferro e da austenita e ferrita expandidas ou fase "S". A presença dos nitretos de ferro é decorrente da decomposição da ferrita expandida. 


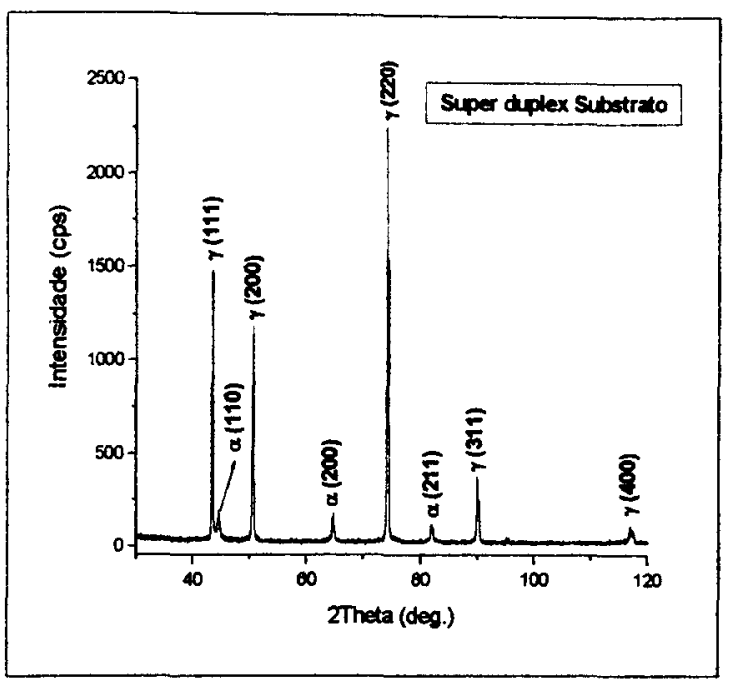

(a)

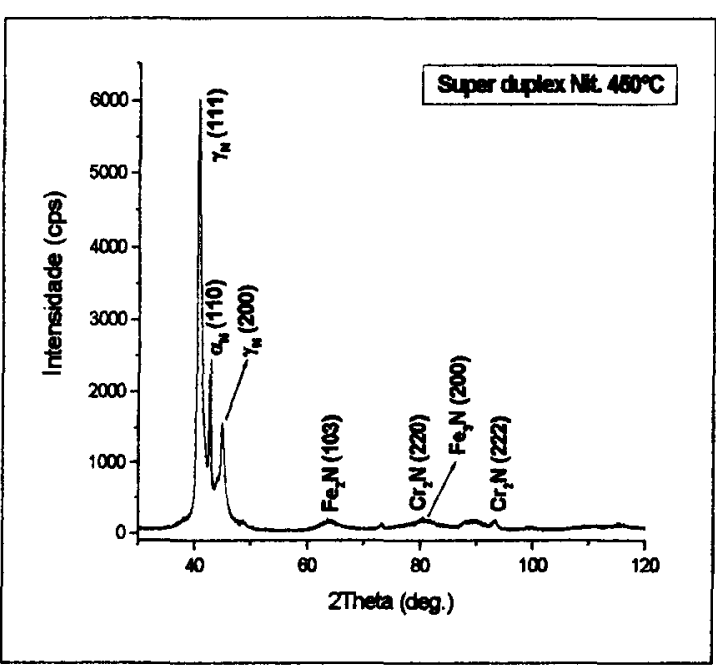

(c)

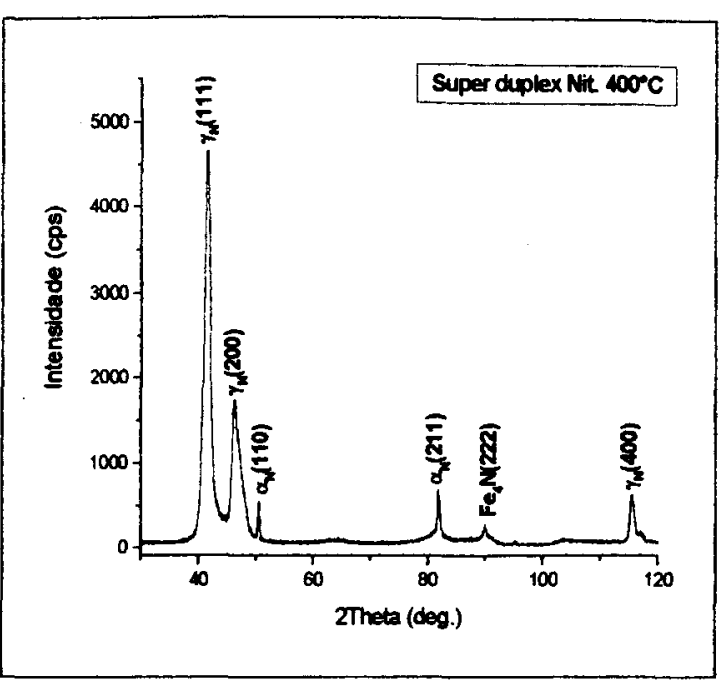

(b)

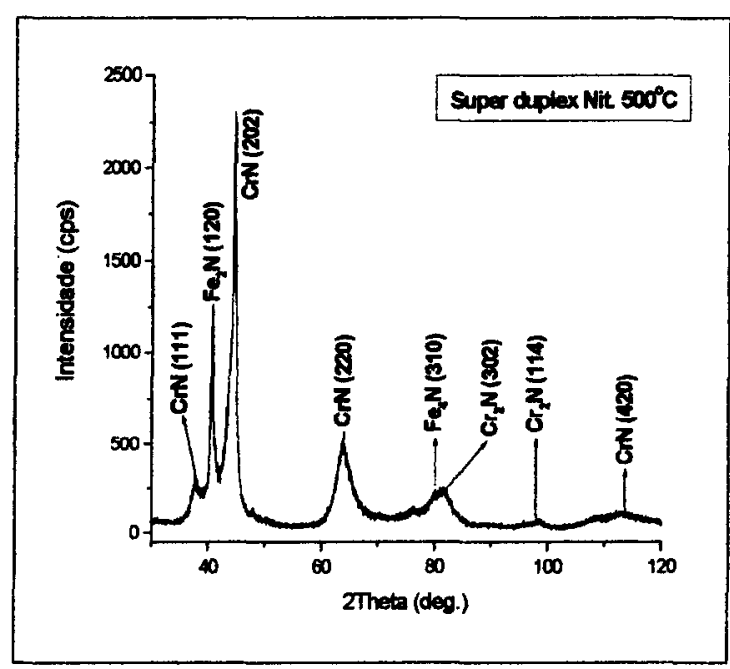

(d)

Figura 33- Difratogramas de raios $X$ das amostras do aço super duplex ASTM A890 Gr5A: (a) substrato; (b) Nit. $400^{\circ} \mathrm{C}$, (c) Nit. $450^{\circ} \mathrm{C}$ e (d) Nit. $500^{\circ} \mathrm{C}$ durante 5 horas.

Verifica-se novamente que os picos do substrato são mais estreitos e com ângulos $2 \theta$ de máximos bem definidos, enquanto que os picos da fase " $S$ " são mais largos, com ângulos $2 \theta$ variando para ângulos mais baixos com a concentração de nitrogênio na fase supersaturada. 
Os difratogramas do substrato e das camadas obtidas nos aço AISI 409 nas temperaturas de 400,450 e $500^{\circ} \mathrm{C}$ são mostrados nas figuras 34 (a), (b) (c) e (d) respectivamente.

Observa-se na figura 34(a) a presença dos picos de difração do ferro alfa ou ferrita do substrato com estrutura cristalina do tipo cúbica de corpo centrado (ccc). Nas figuras $34(b)$ e (c) verifica-se a presença das fases ferrita expandida $\left(\alpha_{N}\right)$ e nitretos de ferro. Tais nitretos apresentam morfologia acicular e também, encontram-se concentrados nos contornos de grãos (ver figuras 13(a) e (b)). Verifica-se que mesmo na temperatura mais baixa de tratamento $\left(400^{\circ} \mathrm{C}\right)$ já ocorreu à formação de nitretos de ferro, decorrentes da decomposição da ferrita expandida $\left(\alpha_{N}\right)$. Com o aumento da temperatura, ocorreram as condições adequadas à formação dos nitretos de cromo, devido ao favorecimento da difusão do cromo com tal aumento da temperatura. Na figura 34(d), o difratograma mostra a presença de várias fases tais como; ferrita expandida $\left(\alpha_{N}\right)$, nitretos de ferro e de nitretos de cromo. 


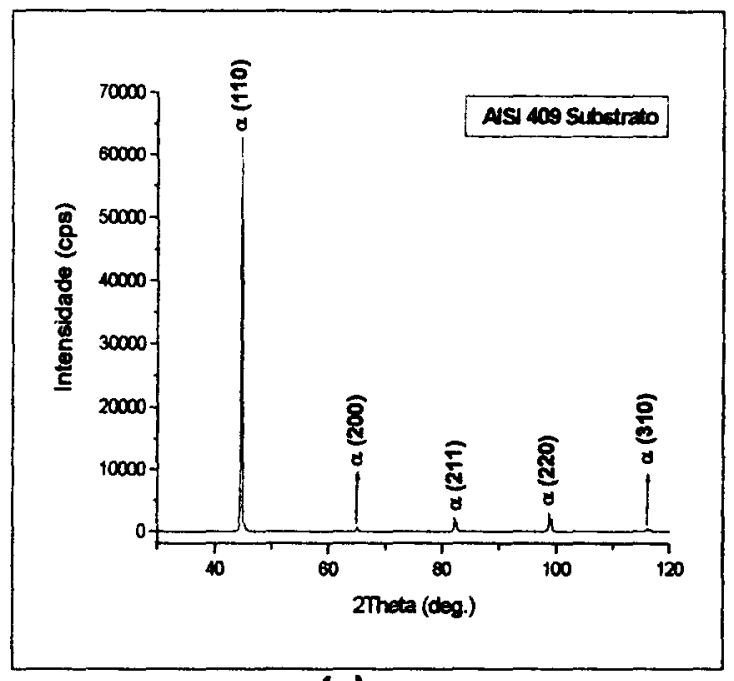

(a)

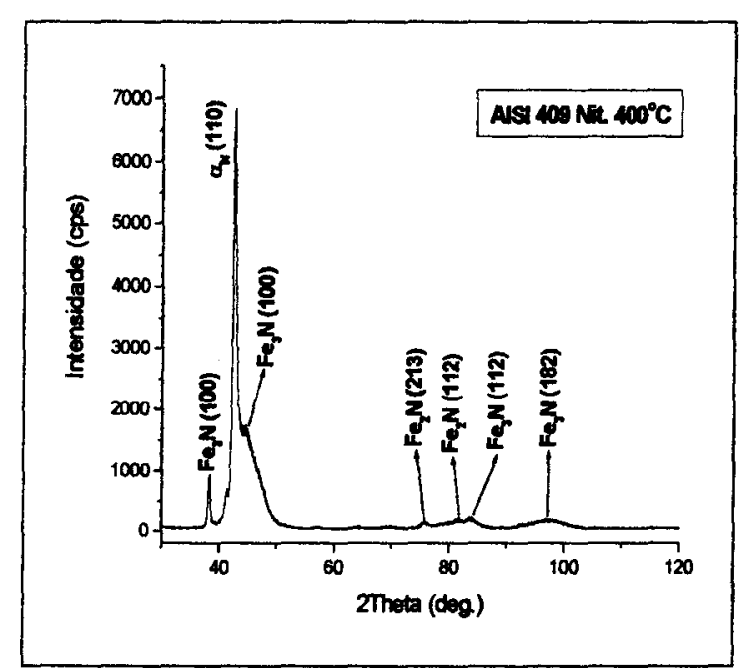

(b)

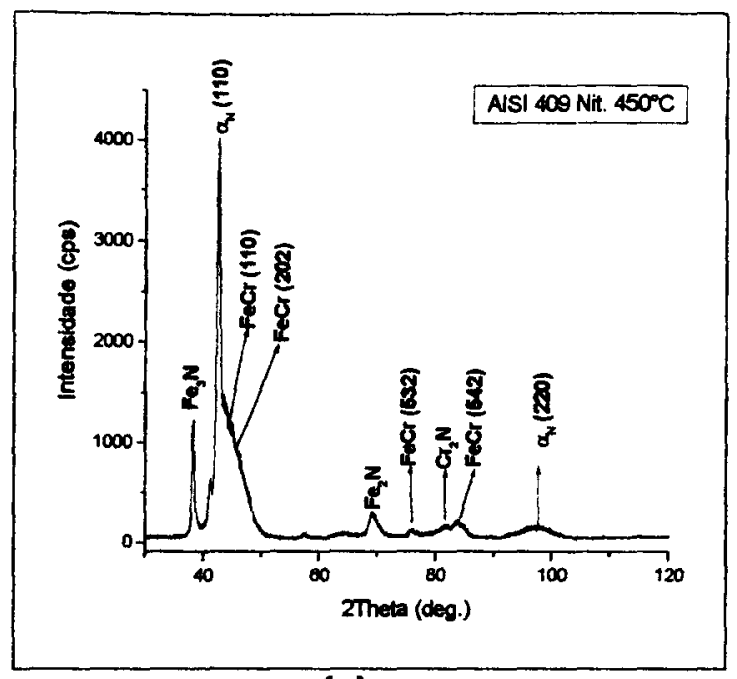

(c)

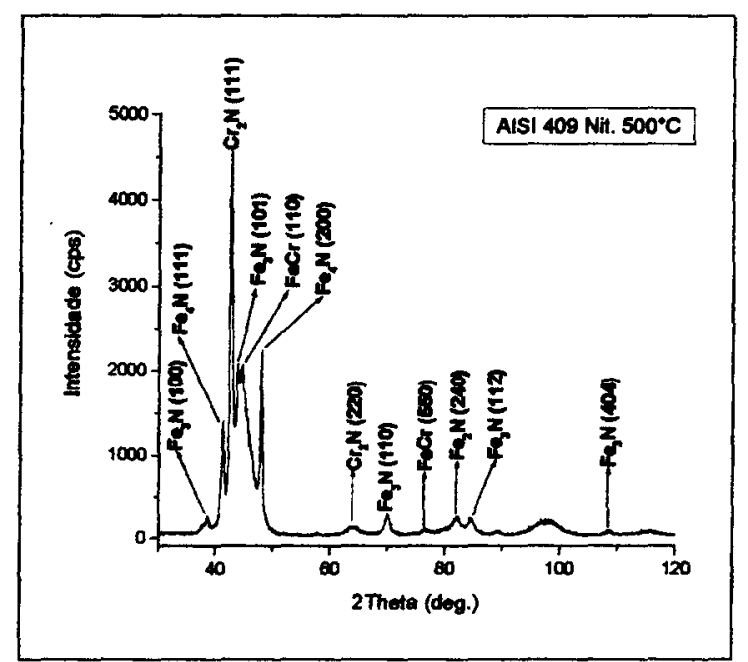

(d)

Figura 34- Difratogramas de raios $X$ das amostras do aço AISI 409: (a) substrato; (b) Nit. $400^{\circ} \mathrm{C}$, (c) Nit. $450^{\circ} \mathrm{C}$ e (d) Nit. $500^{\circ} \mathrm{C}$ durante 5 horas.

Visando-se demonstrar com maior detalhamento o comportamento da austenita com o aumento de temperatura de nitretação, foram nitretados amostras do aço inoxidável austenítico 304 nas temperaturas de 350,380 e $410^{\circ} \mathrm{C}$. Verificase na figura 35 , que à medida que a temperatura aumenta ocorre um aumento na intensidade dos picos de difração da fase " $S$ ", enquanto que a intensidade dos 
picos da austenita do substrato diminui devido à sua substituição gradativa para austenita expandida. Com o aumento da temperatura ocorre um deslocamento dos picos da austenita expandida para ângulos menores, devido à supersaturação de nitrogênio na camada e a conseqüente expansão do parâmetro de rede.

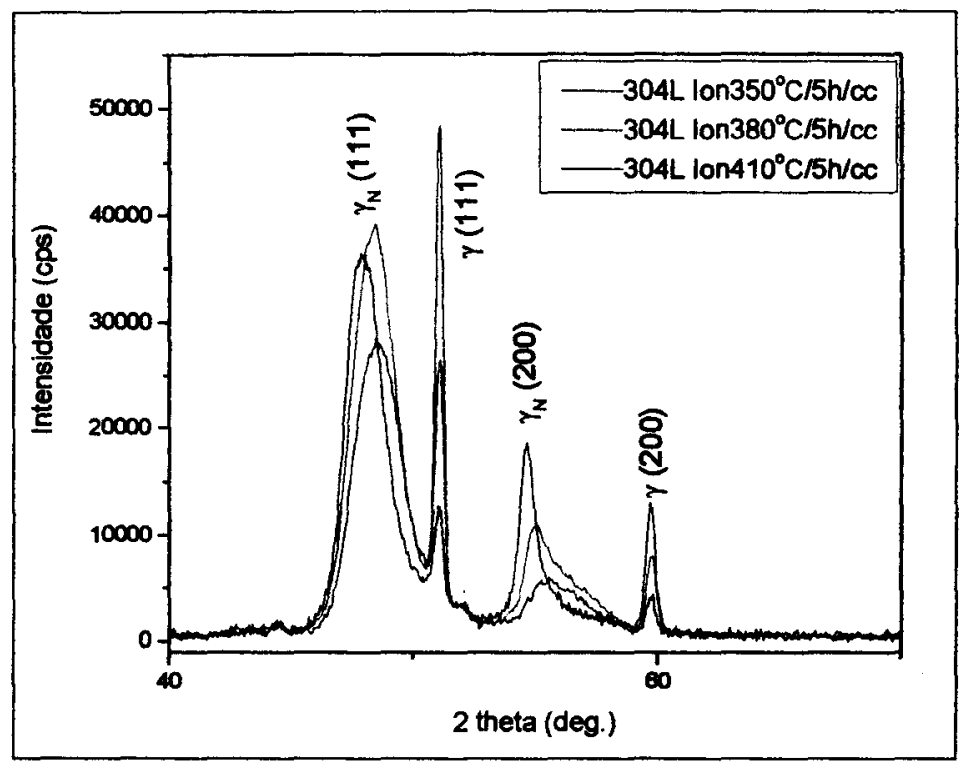

Fig. 35- Difratogramas de raios $X$ das amostras do aço AISI 304 nitretado por plasma nas temperaturas de 350,380 e $410^{\circ} \mathrm{C}$ durante 5 horas.

\subsection{2 - Amostras Carbonitretadas.}

Os difratogramas do substrato e das camadas carbononitretadas do aço AISI 316L são mostrados nas figuras 36(a), (b), (c), e (d). Os picos referentes ao substrato austenítico săo mostrados na figura 36(a). A figura 36(b) apresenta os picos de difração da fase "S" ou austenita expandida (fase clara observada na 
figura 17(a)). Nas figuras $36(c)$ e (d) verifica-se os picos das fases; nitretos e carbonitretos de ferro e de cromo.

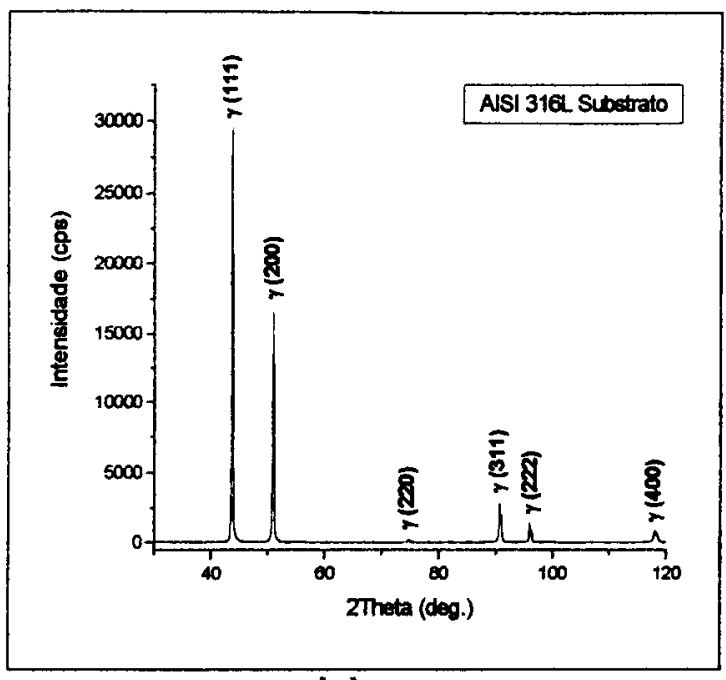

(a)

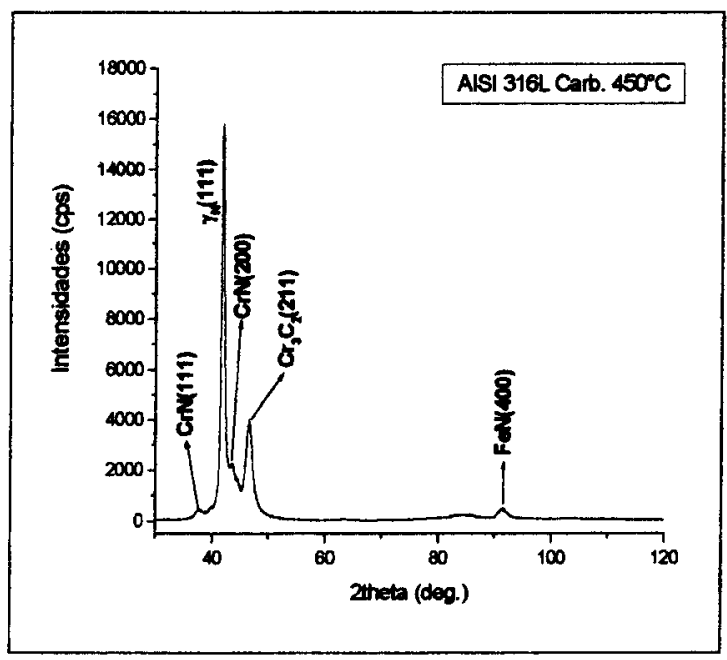

(c)

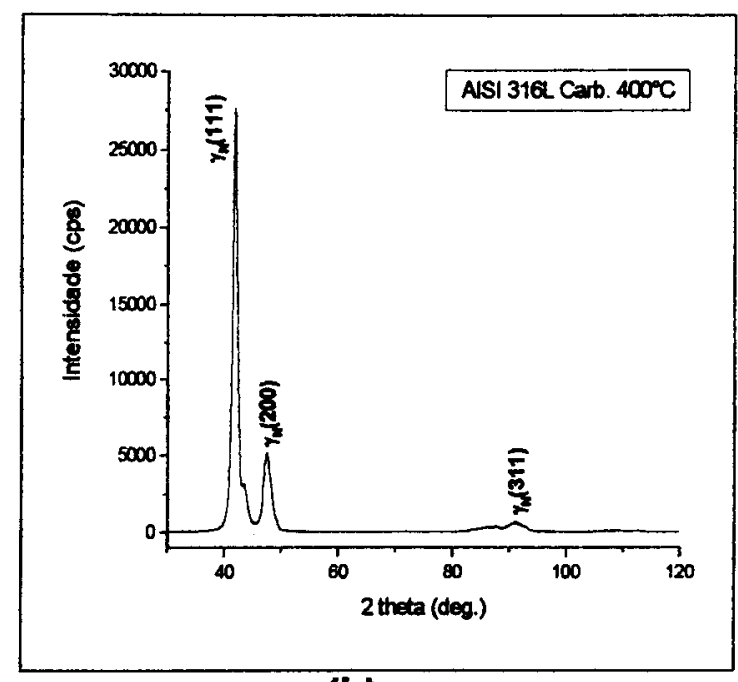

(b)

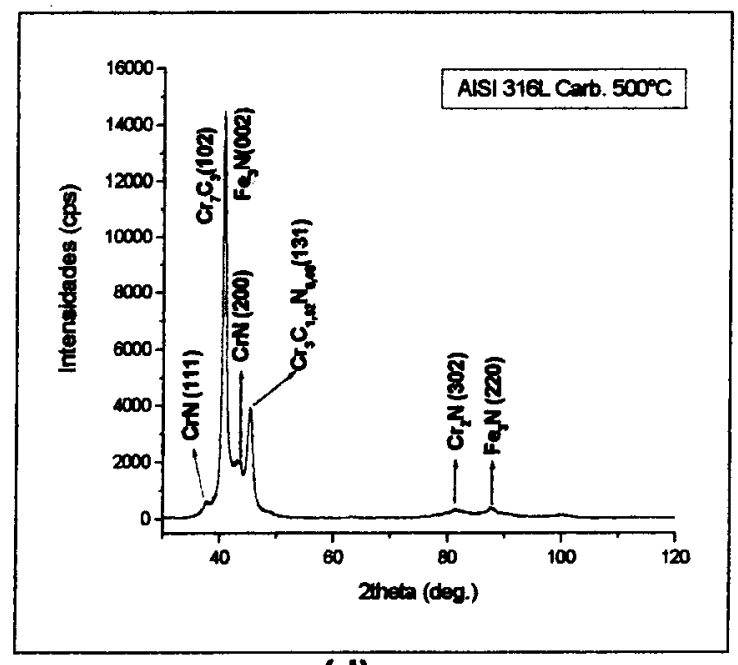

(d)

Figura 36- Difratogramas de raios $X$ das amostras do aço AISI 316L: (a) substrato; (b) Carb. $400^{\circ} \mathrm{C}$, (c) Carb. $450^{\circ} \mathrm{C}$ e (d) Carb. $500^{\circ} \mathrm{C}$ durante 10 horas.

Nas figuras 37 são mostrados os picos padrões de difração de raios $X$ do aço AISI 409 do substrato e das camadas produzidas a 400,345 e $500^{\circ} \mathrm{C}$. Na figura 37(a), observa-se os picos padrões de difração da ferrita, indicando a estrutura cristalina do tipo cúbica de corpo centrado (ccc). 


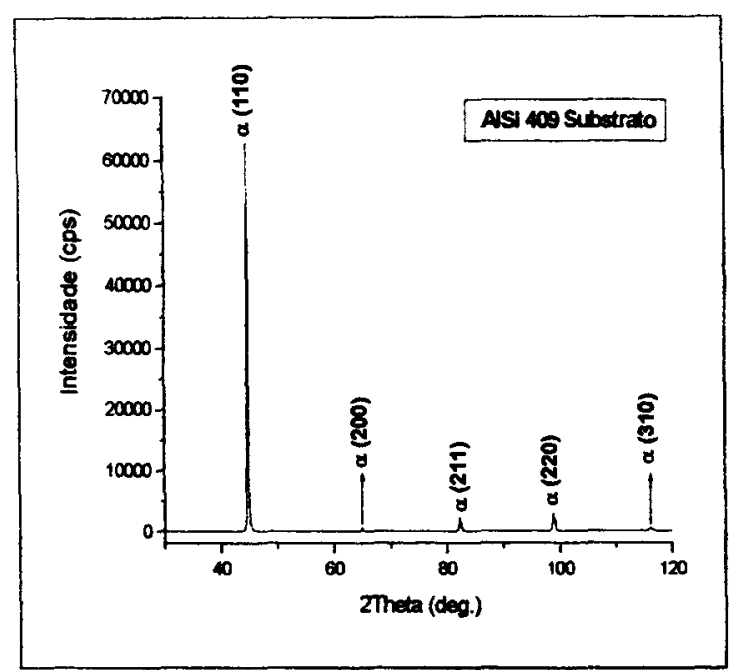

(a)

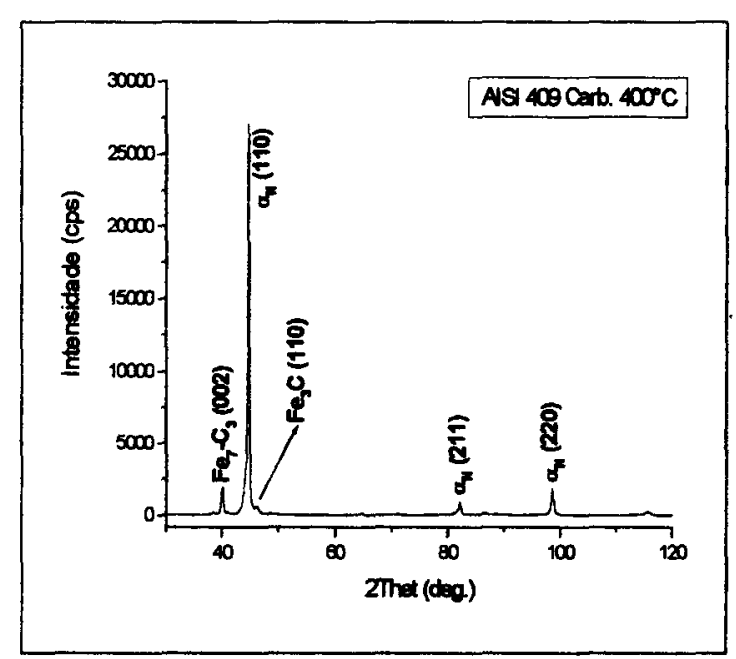

(b)

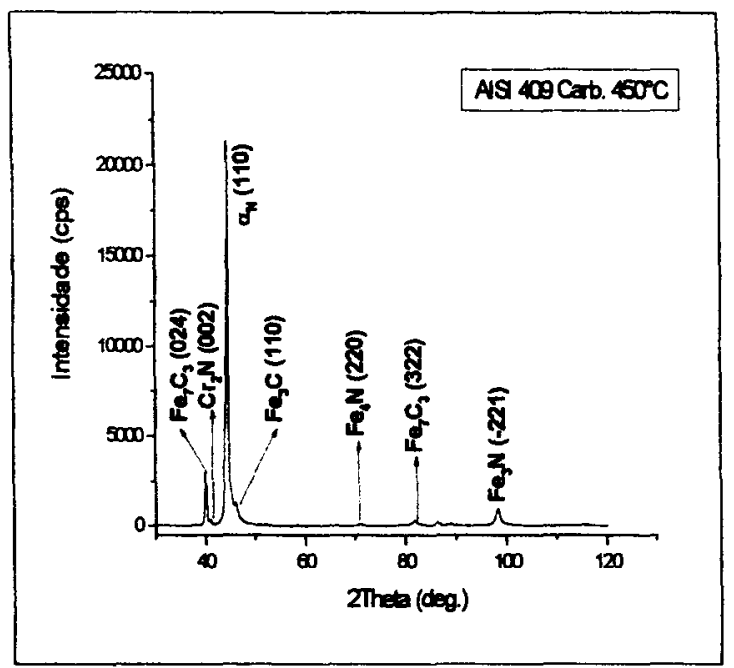

(c)

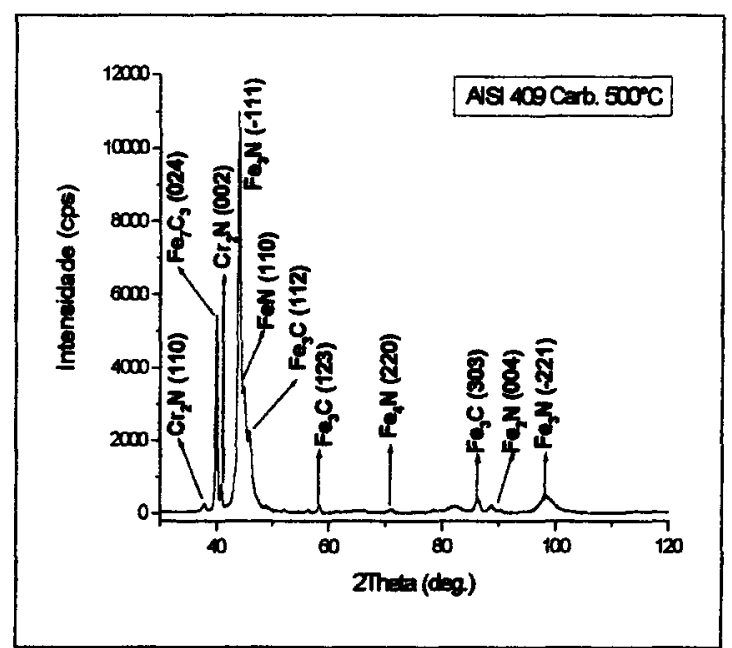

(d)

Figura 37- Difratogramas de raios $X$ das amostras do aço AISI 409: (a) substrato; (b) Carb. $400^{\circ} \mathrm{C}$, (c) Carb. $450^{\circ} \mathrm{C} \mathrm{e} \mathrm{(d)} \mathrm{Carb.} 500^{\circ} \mathrm{C}$ durante 10 horas.

$\mathrm{Na}$ figura 37(b) verifica-se a formaçăo da ferrita expandida, caracterizada pelo alargamento do pico e um pequeno deslocamento para a esquerda. Verifica-se também o início de formaçăo de carboneto de ferro. Com o aumento da temperatura para $450^{\circ} \mathrm{C}$, além das fases formadas anteriormente, ocorreu também o aparecimento de nitretos de cromo. $A 500^{\circ} \mathrm{C}$, acentua-se a formaçăo dos nitretos de cromo e ferro, devido à aceleraçăo da difusão do cromo nessa temperatura. 
$\mathrm{Na}$ figura 38(a), são apresentados os picos de difração correspondentes ao aço super duplex ASTM A890 Gr5A. Verificam-se a presença das fases ferrita e austenita, constituintes do substrato. No caso da camada obtida a $400^{\circ} \mathrm{C}$, verificase a presença de ferrita e austenita expandidas, bem como parte da ferrita se transformou em austenita expandida.

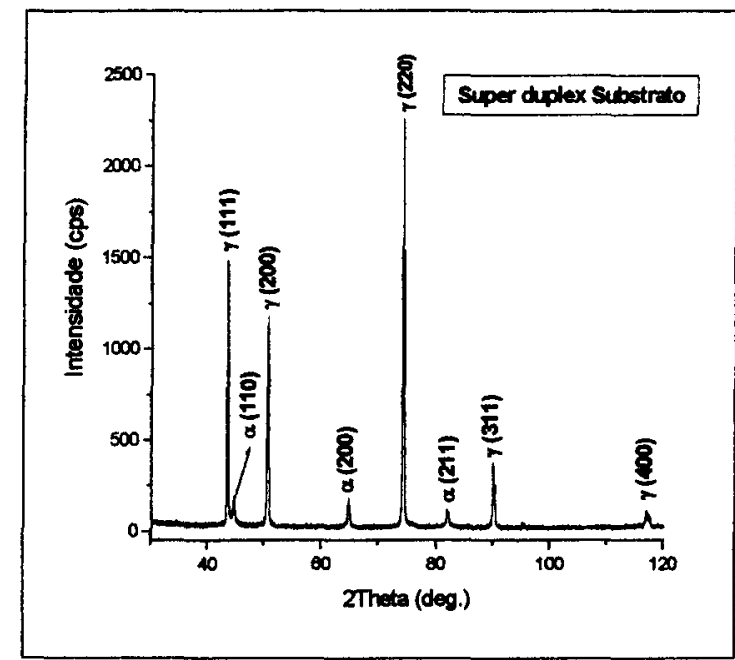

(a)

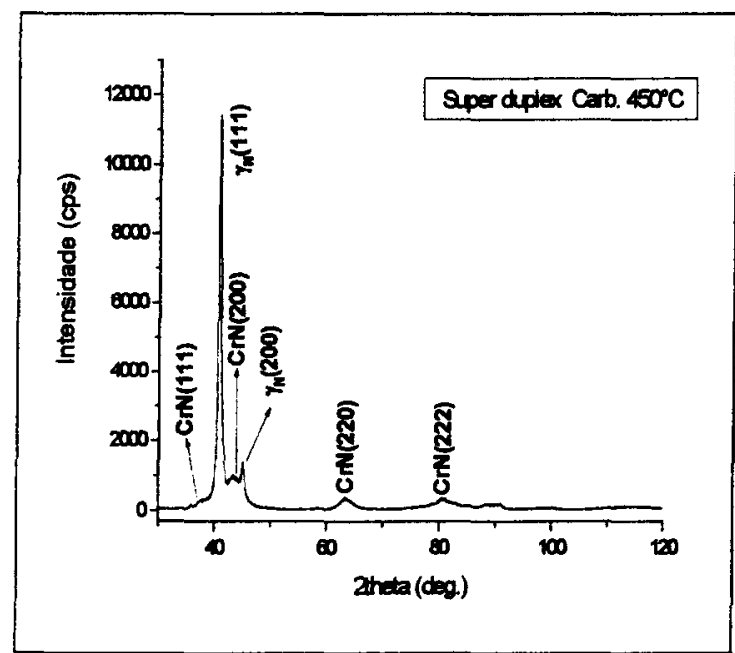

(c)

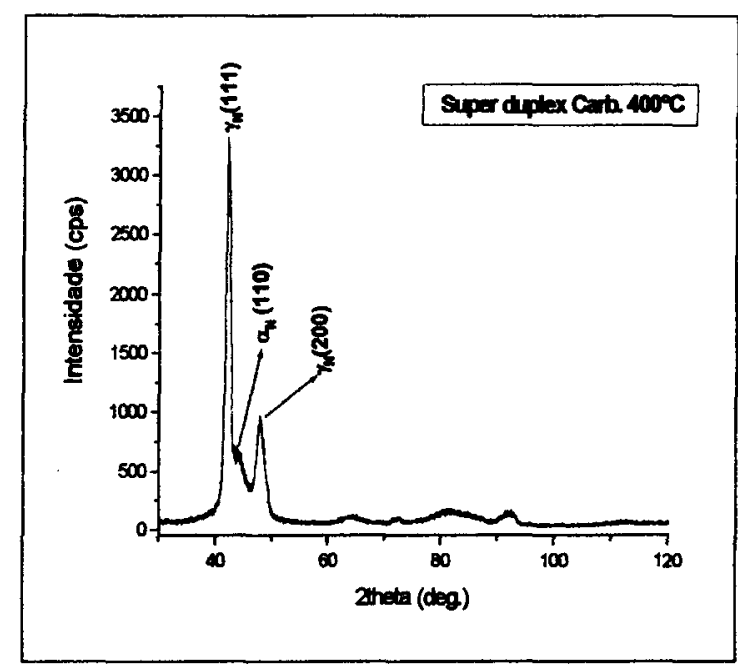

(b)

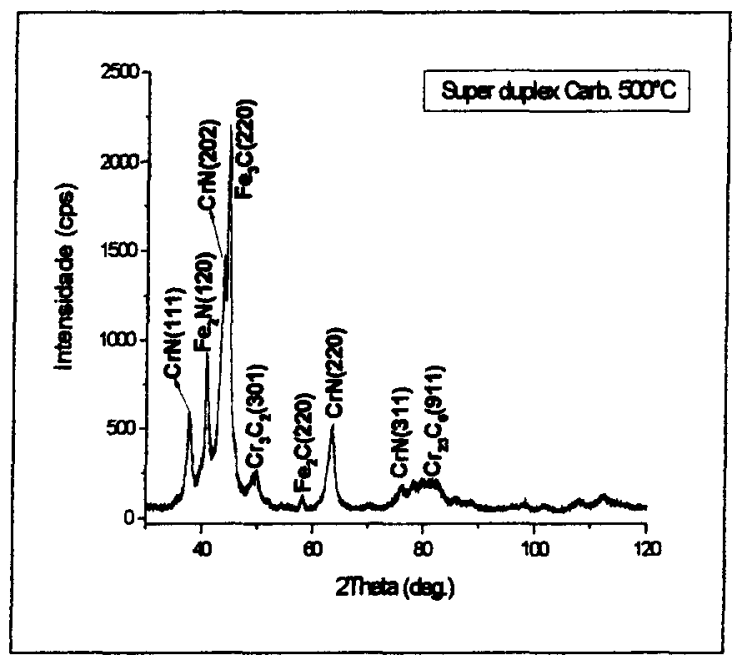

(d)

Figura 38- Difratogramas de raios $X$ das amostras do aço Super duplex ASTM A890 Gr 5A: (a) substrato; (b) Carb. $400^{\circ} \mathrm{C}$, (c) Carb. $450^{\circ} \mathrm{C}$ e (d) Carb. $500^{\circ} \mathrm{C}$ durante 10 horas. 
No tratamento realizado a $450^{\circ} \mathrm{C}$ observa-se a formação de nitretos de cromo. Tais resultados estão de acordo com os resultados obtidos por Blawert et. al. (1996) em seu trabalho.

$\mathrm{Na}$ camada produzida a $500^{\circ} \mathrm{C}$ já ocorreu uma intensa transformação, com decomposição da ferrita e austenita em nitretos e carbonitretos de cromo e ferro. Tal comportamento foi também observado por Mentle e Rie (1999).

\section{5 - ANÁLISES DA RESISTÊNCIA À CORROSÃO POR PITES}

\subsection{1 - Amostras Nitretadas.}

Os ensaios de corrosão foram realizados á temperatura ambiente em solução de cloreto de sódio em concentração de $3,5 \%$, com pH neutro, para determinação do potencial de pites dos substratos e das camadas. As figuras 39 a 41 apresentam as curvas de polarização potenciodinâmicas obtidas por meio dos ensaios realizados para os aços inoxidáveis AISI 316L, 409 e Super duplex na condição nitretados e não nitretados.

A figura 39 apresenta os resultados dos ensaios de corrosão realizados no aço inoxidáveis Super duplex. Verifica-se que a amostra nitretada a $400^{\circ} \mathrm{C}$ apresenta tanto uma resistência à corrosão por pite $\left(E_{\text {pite }}\right)$ quanto um potencial de repassivação superior ao do substrato, indicando que o tratamento aumentou a resistência à corrosão por pite, em comparação com o substrato. Tal fato deveu-se 
às presenças da austenita e ferrita expandidas, comprovando a efetividade das mesmas quanto a essa propriedade.

No caso das amostras nitretadas a $450^{\circ} \mathrm{C}$ e $500^{\circ} \mathrm{C}$ ocorreu uma queda na resistência à corrosão em comparação com a do substrato, embora verifique-se tendências à passivação na camada produzida a $450^{\circ} \mathrm{C}$. Tal queda deve-se à formação de nitretos de cromo, o que empobrece o substrato em cromo e nitrogênio em soluçăo sólida.

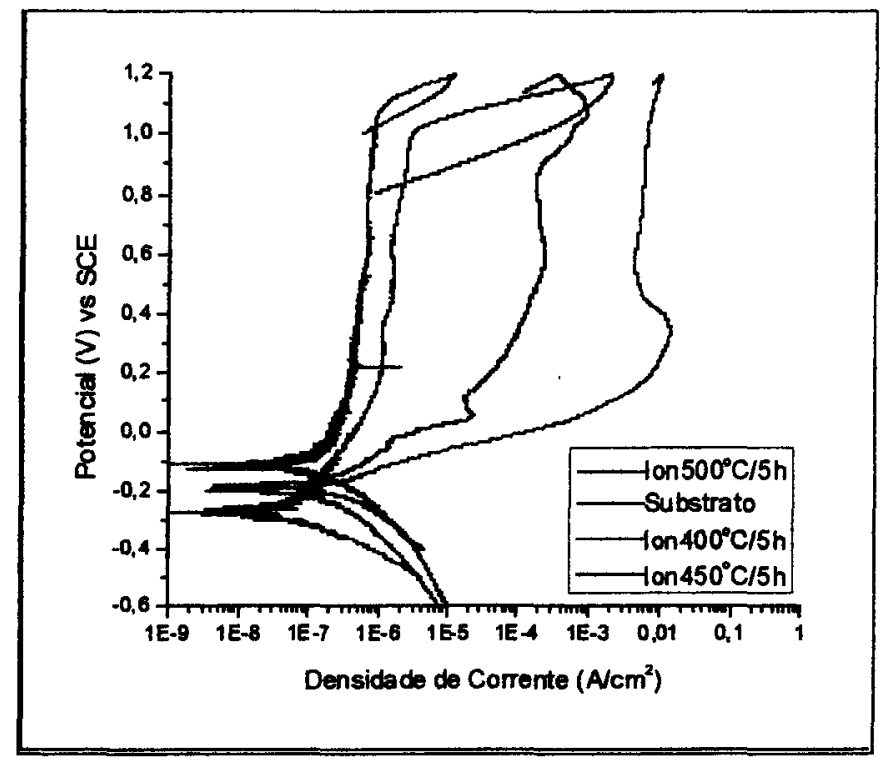

Figura. 39 Curvas de polarizaçăo anódicas potenciodinâmicas do aço inoxidável superduplex ASTM A890 Gr 5A solubilizado e nitretado por plasma nas temperaturas de $400^{\circ} \mathrm{C}, 450^{\circ} \mathrm{C}$ e $500^{\circ} \mathrm{C}$, obtidas em solução de cloreto $3,5 \%$ a temperatura ambiente e pHigual a 7 .

Verifica-se que o substrato apresentou potencial de repassivaçăo (laço da curva 39) devido ao seu elevado PREN=41,75. Os demais substratos (AISI 316L e 409) com PREN mais baixos 25,1 e 11,6 respectivamente não apresentaram essa caracteristica.

A figura $\mathbf{4 0}$ mostra as curvas de polarizaçăo anódicas para o aço inoxidável AISI 409 na condição não nitretada e nitretada nas temperaturas de $400^{\circ} \mathrm{C}, 450^{\circ} \mathrm{C}$ e 
$500^{\circ} \mathrm{C}$. Verifica-se que nas amostras tratadas a $400,450^{\circ} \mathrm{C}$ tanto 0 potencial de corrosão quanto a densidade de corrente apresentaram uma melhora significativa em relaçăo ao substrato indicando que o nitrogênio incorporado na camada superficial, impede a dissolução anódica, resultando numa densidade de corrente mais baixa e uma melhor resistência à corrosão. Portanto, a passividade e a resistência à corrosăo por pite do aço inoxidável AISI 409 foram melhoradas por meio da nitretação por plasma nas temperaturas de $400^{\circ} \mathrm{C}$ e $450^{\circ} \mathrm{C}$.

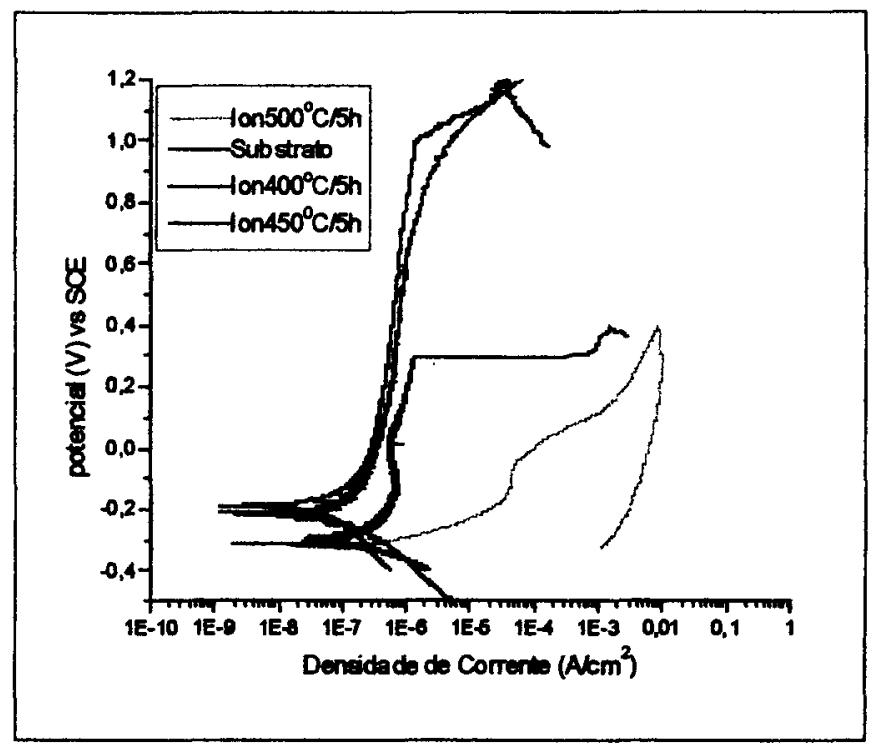

Figura. 40 - Curvas de polarizaçăo anódicas potenciodinåmicas do aço inoxidável AISI 409 solubilizado e nitretado por plasma nas temperaturas de $400^{\circ} \mathrm{C}, 450^{\circ} \mathrm{C}$ e $500^{\circ} \mathrm{C}$, obtidas em soluçăo de cloreto $3,5 \%$ a temperatura ambiente e pHigual a 7.

A amostra nitretada a $500^{\circ} \mathrm{C}$ apresentou a maior taxa de corrosăo, inclusive muito superior à do substrato, devido à presença de nitretos de cromo (CrN), que apresentam características de corrosåo inferiores às da fase " $S$ ", que possui alto teor de nitrogénio dissolvido e conseqüentemente um alto valor de PREN (número equivalente de resistência ao pite). 
A figura 41 mostra as curvas de polarização anódicas para 0 aço inoxidável AISI $316 \mathrm{~L}$ e para as camadas produzidas nas temperaturas de 400,450 e $500^{\circ} \mathrm{C}$. Observa-se que a resistência à corrosão generalizada da amostra nitretada a $400^{\circ} \mathrm{C}$ é superior à da amostra não nitretada e nitretadas a 450 e $500^{\circ} \mathrm{C}$.

Os tratamentos a 450 e $500^{\circ} \mathrm{C}$ produziram uma deterioração acentuada nas resistências à corrosăo das camadas nestes aços.

Esses resultados confirmam que nestes aços as camadas nitretadas obtidas em baixas temperaturas apresentam melhor resistência à corrosão por pite do que as amostras não tratadas, fato que se deve à maior concentração de nitrogênio mantido em solução sólida formando a chamada "austenita expandida" ou fase "S", (ver figura 32(b) e 35), resultados semelhantes foram obtidos por, Fewell et. al. (2000-(a)); Fewell et. al. (2000-(b)).

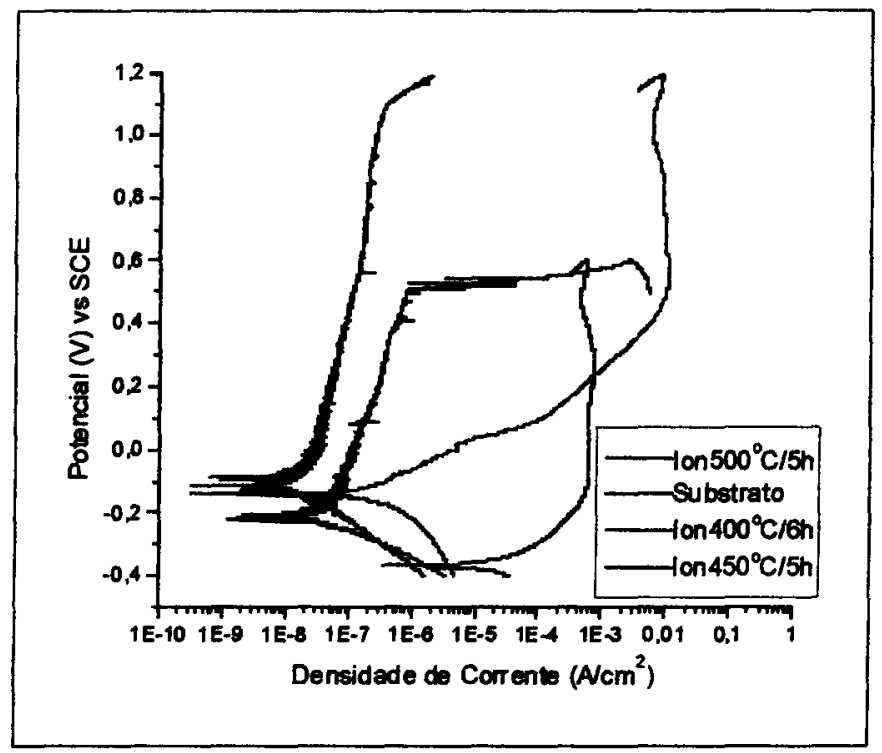

Figura. 41 - Curvas de polarizaçăo anódicas potenciodinâmicas do aço inoxidável AISI $316 \mathrm{~L}$ solubilizado e nitretado por plasma nas temperaturas de $400^{\circ} \mathrm{C}, 450^{\circ} \mathrm{C}$ e $500^{\circ} \mathrm{C}$, obtidas em solução de cloreto $3,5 \%$ a temperatura ambiente e pH igual a 7. 
Verifica-se também, que as curvas das amostras nitretadas a 450 e $500^{\circ} \mathrm{C}$, são deslocadas mais para a direita e não apresentaram passivação. A causa desse efeito está relacionada à precipitação dos nitretos de cromo e formação de ferrita na região próxima a superfície da camada de difusão, acompanhada de uma diminuição do teor de cromo da austenita do substrato, Czerwiec et al. (2000). Observa-se que não ocorreu a formação de pite nas camadas nitretadas a 450 e $500^{\circ} \mathrm{C}$ uma vez a corrosão generalizada metal.

$\mathrm{Na}$ amostra nitretada a $400^{\circ} \mathrm{C}$ ocorreu à formação de pite para um potencial de $1120 \mathrm{mV}$, enquanto que a formação de pite no substrato ocorreu para um potencial de $290 \mathrm{mV}$, indicando um aumento no minimo de 3,5 vezes no potencial de pite do aço. Fica claro que quando a nitretação por plasma é realizada em temperatura baixa $\left(<450^{\circ} \mathrm{C}\right)$, a densidade corrente crítica $\left(i_{\text {corr }}\right)$ aumenta levemente em relação ao material não tratado, mas, as características de passivação do aço são mantidas.

\subsection{2 - Amostras Carbonitretadas.}

As figuras 42 a 44 apresentam as curvas de polarização potenciodinâmicas obtidas por meio dos ensaios realizados para os aços inoxidáveis AISI 316L, 409 e super duplex na condição carbonitretados e não carbonitretados.

A figura 42 mostra as curvas de polarização anódicas para o aço inoxidável AISI 409 do substrato e na condição carbonitretado nas temperaturas de 400, 450 e $500^{\circ} \mathrm{C}$. 


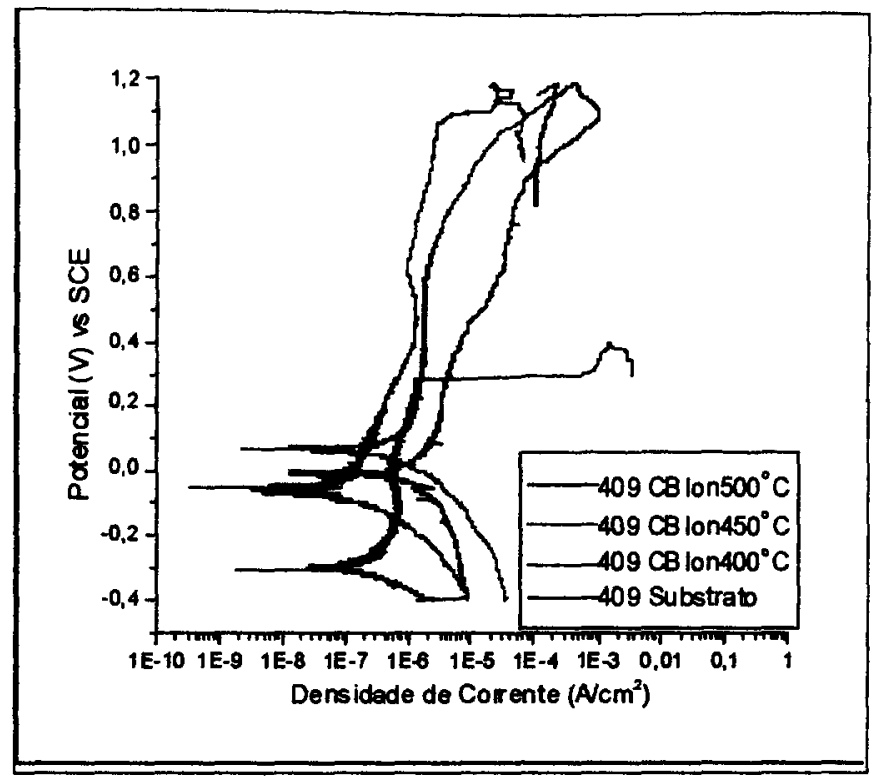

Figura 42- Curvas de polarização anódica potenciodinâmicas do aço inoxidável AISI 409 solubilizado e carbonitretado por plasma nas temperaturas de $400^{\circ} \mathrm{C}, 450^{\circ} \mathrm{C}$ e $500^{\circ} \mathrm{C}$, obtidas em solução de cloreto $3,5 \%$ a temperatura ambiente e pHigual a 7.

Analisando-se a figura, verifica-se que a resistência à corrosão por pites do aço inoxidável AISI 409 foi evidentemente melhorada por meio da carbonitretação por plasma nas temperaturas de 400 e $450^{\circ} \mathrm{C}$ em comparação com o substrato. Este comportamento foi semelhante ao das amostras nitretadas nessas temperaturas, indicando o papel predominante da fase " $S$ " na resistência à corrosão. A boa resistência à corrosăo das amostras carbonitretadas nessas temperaturas se deve à maior concentraçăo dos elementos intersticiais nitrogênio e carbono mantidos em solução sólida, dificultando a precipitaçăo dos nitretos e carbonitretos de cromo. Por outro lado, a carbonitretação a $500^{\circ} \mathrm{C}$ deslocou a curva mais para a direita, porém, sua passivação foi mantida.

A figura 43 mostra as curvas de polarizaçăo anódica para o aço inoxidável AISI 316L na condição carbonitretado e não carbonitretado nas temperaturas de 400,450 e $500^{\circ} \mathrm{C}$. Observa-se que as três amostras apresentaram um comportamento eletroquímico semelhante, com pouca diferença na densidade de 
corrente, apresentando melhores resistências à corrosão por pites que o substrato e comportamento de passivação semelhantes ao de substrato. Verifica-se também, que o potencial de corrosão de todas as amostras tratadas aumentou levemente em relação ao material não tratado, demonstrando uma melhor resistência à corrosão da camada obtida.

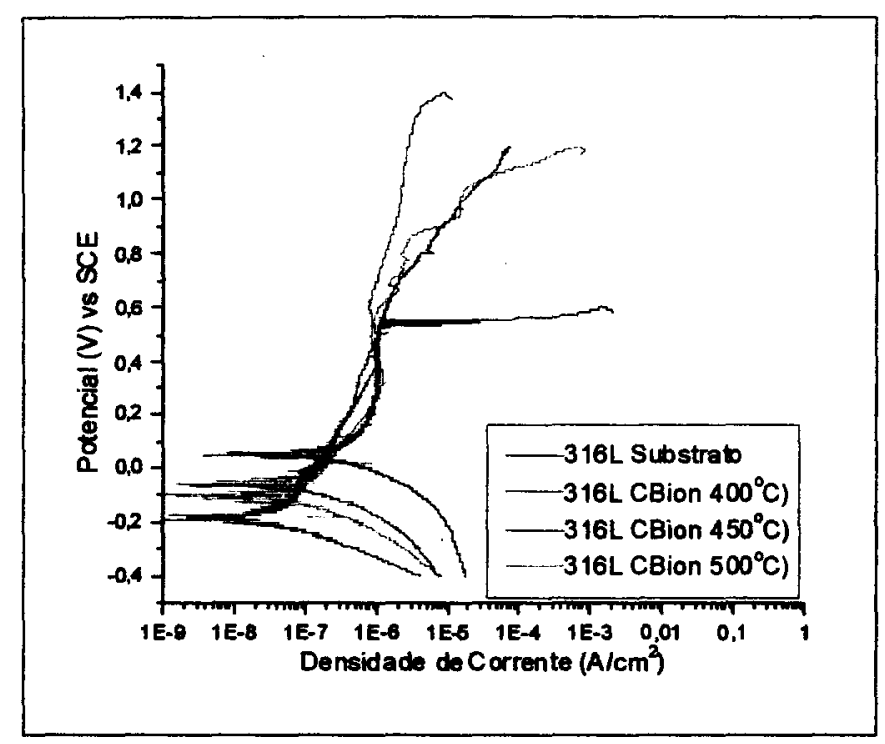

Figura 43 - Curvas de polarização anódica potenciodinâmicas do aço inoxidável AISI 316L solubilizado e carbonitretado por plasma nas temperaturas de $400^{\circ} \mathrm{C}, 450^{\circ} \mathrm{C}$ e $500^{\circ} \mathrm{C}$, obtidas em soluçăo de cloreto $3,5 \%$ a temperatura ambiente e pHigual a 7 .

Nas amostras carbonitretadas a 450 e $500^{\circ} \mathrm{C}$, durante 0 ensaio eletroquímico a camada é corroída mais lentamente no início e depois de certo potencial a taxa de corrosão aumenta, provavelmente, devido a influência dos carbonitretos de cromo de cromo formados na camada.

Comparando-se os comportamentos das amostras nitretadas com o das carbonitretadas, apenas no caso da amostra tratada a $400^{\circ} \mathrm{C}$ a condição nitretada apresentou melhor desempenho. Nas demais temperaturas as carbonitretadas foram superiores. 
O aumento na resistência à corrosão por pites desse material está relacionado com a formação de uma solução sólida supersaturada de carbono e nitrogênio com uma estrutura tetragonal de faces centrada (fct), Cheng et al. (2004).

A figura 44 apresenta as curvas de polarização anódicas realizadas no aço inoxidáveis super duplex ASTM A890 Gr5A. Para ambas as amostras, a passivação foi mantida, e, praticamente não se observa variação na densidade de corrente passiva das amostras em estudos. Nas curvas também se observa que após atingir o estado de passivaçăo a taxa de corrosão do aço é relativamente baixa, e quando - potencial alcança certo valor, inicia-se a corrosão por pite, resultando num repentino aumento na densidade de corrente.

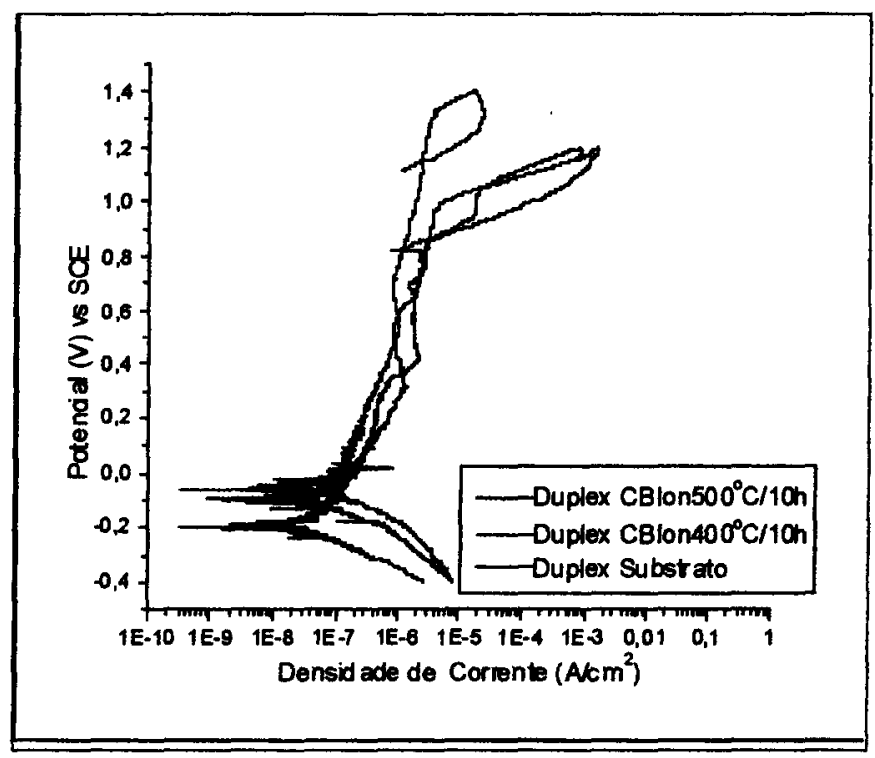

Figura 44 - Curvas de polarizaçăo anódicas potenciodinâmicas do aço inoxidável super duplex ASTM A890 Gr 5A solubilizado e carbonitretado por plasma nas temperaturas de $400^{\circ} \mathrm{C}$ e $500^{\circ} \mathrm{C}$, obtidas em solução de cloreto $3,5 \%$ a temperatura ambiente e pHigual a 7 .

As amostras carbonitretadas a 400 e $500^{\circ} \mathrm{C}$ apresentaram comportamentos semelhantes ao do substrato, quanto à corrosão. No caso da tratada a $400^{\circ} \mathrm{C}$, a resistẻncia à corrosão por pite foi superior. 
Todos os tratamentos de nitretação ou carbonitretação por plasma, realizados na temperatura de $400^{\circ} \mathrm{C}$, para todos os aços em estudo, apresentaram comportamentos de passivação e de resistência ao pite superiores aos dos materiais base. Isto comprova a eficácia de fase " $S$ " (austenita ou ferrita expandidas) na resistência à corrosão. Resultados semelhantes também foram observados pelos pesquisadores Blawert et. al. (2001).

As camadas obtidas por carbonitretação apresentaram desempenhos semelhantes aos dos substratos quanto à corrosão generalizada e muito superior com relação à resistência ao pite, independentemente das temperaturas de tratamento. As amostras carbonitretadas a 450 e $500^{\circ} \mathrm{C}$ apresentaram resistências à corrosão muito superior às das nitretadas nessas temperaturas. Tal fato decorre da maior estabilidade da camada carbonitretada em comparação com a nitretada, decorrente do retardamento da formação dos nitretos de cromo devido à competição difusional carbono/nitrogênio (figura 12c-16c).

Outro fator altamente significativo na temperatura de $500^{\circ} \mathrm{C}$ foi a formação dos nitretos de cromo no sentido de dentro para fora (figuras $15 \mathrm{c}$ e 16c).

Verifica-se na figura $13 \mathrm{c}$, que mesmo tratado a $500^{\circ} \mathrm{C}$, o aço AISI316 L ainda apresenta uma camada significativa da fase " $S$ ". Acima dela, e de dentro para fora, formaram-se os nitretos (fase escura). Acima desses nitretos permanece ainda uma camada constituída da fase " $S$ ", que foi a responsável pela resistência à corrosão apresentada nos ensaios.

$\mathrm{Na}$ figura $16 \mathrm{c}$, correspondente ao aço super duplex carbonitretado a $500^{\circ} \mathrm{C}$, verifica-se a estabilidade da fase " $\mathrm{S}$ " formada sobre a austenita (fase marrom), enquanto que na ferrita (fase verde) e no sentido de dentro para fora da camada, verifica-se a formação gradual de nitretos, enquanto que superficialmente a camada se mantém estável, sendo a responsável pela resistência à corrosão. 
As curvas de polarização anódicas das amostras nitretadas por plasma, obtidas nas temperaturas de 450 e $500^{\circ} \mathrm{C}$, observa-se um deslocamento das mesmas para valores de correntes mais elevados, provavelmente devido à presença de nitretos de cromo $\left(\mathrm{Cr}_{2} \mathrm{~N}\right)$, como observado nas micrografias óticas, (ver figuras, 11c, 12c e 13c).

Verifica-se que o potencial de pite do substrato é muito bem definido para os três aços em estudo. No entanto, as amostras nitretadas e carbonitretadas na temperatura de $400^{\circ} \mathrm{C}$, esse potencial é deslocado para altos valores de potenciais anódicos, devido à formação de uma solução sólida supersaturada com nitrogênio e/ou carbono, denominada de fase "S".

$\mathrm{Na}$ tabela 08 são apresentados os resultados gerais obtidos das curvas de polarização anódicas, realizados nas camadas nitretadas e carbonitretadas nos aços inoxidáveis austenítico AISI 316L, ferrítico AISI 409 e super duplex ASTM A $890 \mathrm{Gr} 5 \mathrm{~A}$. Observa-se por meio desses resultados que os aços inoxidáveis nitretados, podem ter um aumento ou redução na resistência à corrosão, dependendo da temperatura de tratamento utilizada.

Verifica-se por meio desses resultados que os aços inoxidáveis austeníticos AISI $316 \mathrm{~L}$ e ferrítico AISI409, tratados a $400^{\circ} \mathrm{C}$, tanto nitretados quanto carbonitretados, tiveram um aumento no potencial de formação de pite de $100 \%$, quando comparados com o substrato. 
Tabela 08 - Medidas da densidade de corrente de corrosão e de formação de pites ( $I_{\text {corr }}$ e $\left.l_{\text {pite }}\right)$, potencial de corrosão $\left(E_{\text {corr }}\right)$ e de formação de pites $\left(E_{\text {pite }}\right)$ dos aços inoxidáveis austeniticos AISI 316L, ferríticos AISI 409 e super duplex ASTM A890 Gr 5 A.

\begin{tabular}{|c|c|c|c|c|}
\hline \multirow{2}{*}{ AÇO } & \multicolumn{4}{|c|}{ Temperaturas de Tratamento $\left({ }^{\circ} \mathrm{C}\right)$} \\
\hline & Substrato & 400 & 450 & 500 \\
\hline AISI 316L & \multicolumn{4}{|c|}{ Nitretado por plasma } \\
\hline$I_{c o r r}\left(A / \mathrm{cm}^{2}\right)$ & $1,25 \times 10^{-8}$ & $7,27 \times 10^{-9}$ & $5,07 \times 10^{-6}$ & $4,46 \times 10^{6}$ \\
\hline$E_{\text {or }}(M)$ & $-0,21$ & $-0,11$ & 0,36 & $-0,14$ \\
\hline $\operatorname{lom}\left(\mathrm{Acm}^{2}\right)$ & $9.33 \times 10^{-7}$ & $3,27 \times 10^{-7}$ & -1 & - \\
\hline EN $(\mathrm{M})$ & 0,52 & 1,10 & -1 & 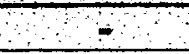 \\
\hline AISI 316L & \multicolumn{4}{|c|}{ Carbonitretado por plasma } \\
\hline$I_{\text {cor }}\left(A / \mathrm{cm}^{2}\right)$ & $1,25 \times 10^{-8}$ & $4,92 \times 10^{-8}$ & $1,36 \times 10^{-7}$ & $3,64 \times 10^{-8}$ \\
\hline$E_{\text {corr }}(V)$ & $-0,21$ & $-0,06$ & 0,05 & $-0,10$ \\
\hline$I_{\text {pite }}\left(\mathrm{A} / \mathrm{cm}^{2}\right)$ & $9,33 \times 10^{-7}$ & $4,01 \times 10^{-6}$ & $7,24 \times 10^{-5}$ & $1,69 \times 10^{-5}$ \\
\hline$E_{\text {pito }}(V)$ & 0,52 & 1,34 & 1,21 & 1,03 \\
\hline ASI 409 & \multicolumn{4}{|c|}{ Nitrotado por plasma } \\
\hline $\operatorname{loor}\left(A / \mathrm{cm}^{2}\right)$ & $9,65 \times 10^{8}$ & $3,16 \times 10^{-8}$ & $9,75 \times 10^{8}$ & $1,37 \times 10^{-7}$ \\
\hline$E_{\text {corr }}(V)$ & $-0,30$ & $-0,21$ & $-0,18$ & $-0,32$ \\
\hline$I_{\text {pite }}\left(\mathrm{A} / \mathrm{cm}^{2}\right)$ & $1,43 \times 10^{-6}$ & $4,17 \times 10^{-6}$ & $1,41 \times 10^{-6}$ & - \\
\hline$E_{\text {pito }}(V)$ & 0,30 & 0,97 & 1,0 & - \\
\hline AISI 409 & \multicolumn{4}{|c|}{ Carbonitretado por plasma } \\
\hline$l_{\text {corr }}\left(A / \mathrm{cm}^{2}\right)$ & $9,65 \times 10^{-8}$ & $5,21 \times 10^{-8}$ & $1,25 \times 10^{-7}$ & $3,0 \times 10^{-7}$ \\
\hline$E_{c o r r}(V)$ & $-0,30$ & 0,06 & $-0,06$ & $-0,01$ \\
\hline $\mathrm{I}_{\text {pito }}\left(\mathrm{A} / \mathrm{cm}^{2}\right)$ & $1,43 \times 10^{-6}$ & $3,45 \times 10^{-6}$ & $3,62 \times 10^{-5}$ & $9,50 \times 10^{-5}$ \\
\hline$E_{\text {pito }}(V)$ & 30 & 1,10 & 1,06 & 0,93 \\
\hline Super duplex & \multicolumn{4}{|c|}{ Nitrotado por plasma } \\
\hline $\mathrm{I}_{\text {cer }}\left(\mathrm{A} / \mathrm{cm}^{2}\right)$ & $1,42 \times 10^{-8}$ & $5,38 \times 10^{-8}$ & $6,26 \times 10^{-8}$ & $2,46 \times 10^{-8}$ \\
\hline$E_{\text {corr }}(N)$ & $-0,20$ & $-0,11$ & $-0,11$ & 0,20 \\
\hline$I_{\text {pin }}\left(A / \mathrm{cm}^{2}\right)$ & $4,88 \times 10^{-6}$ & $1,14 \times 10^{-8}$ & - & - \\
\hline$E_{\text {on }}(N)$ & 1,0 & 1,11 & $=$ & - \\
\hline$I_{\text {nopomen }}\left(\mathrm{Acm}^{2}\right)$ & $3,14 \times 10^{-6}$ & $7,78 \times 10^{-7}$ & - & $=$ \\
\hline$E_{\text {roman }}(V)$ & 0,87 & 1,02 & - & - \\
\hline Super duplex & \multicolumn{4}{|c|}{ Carbonltretado por plasma } \\
\hline$I_{\text {cor }}\left(A / \mathrm{cm}^{2}\right)$ & $1,42 \times 10^{-8}$ & $3,11 \times 10^{-8}$ & - & $3,38 \times 10^{-8}$ \\
\hline$E_{\operatorname{cor}}(V)$ & $-0,20$ & $-0,06$ & - & $-0,11$ \\
\hline$I_{\text {pite }}\left(\mathrm{A} / \mathrm{cm}^{2}\right)$ & $4,88 \times 10^{-6}$ & $3,45 \times 10^{-6}$ & - & $2,35 \times 10^{-5}$ \\
\hline$E_{\text {pite }}(V)$ & 1,0 & 1,32 & - & 1,06 \\
\hline $\mathrm{I}_{\text {repases }}\left(\mathrm{A} / \mathrm{cm}^{2}\right)$ & $3,14 \times 10^{-6}$ & $2,42 \times 10^{-6}$ & - & - \\
\hline$E_{\text {repos }}(V)$ & 0,87 & 1,14 & - & \\
\hline
\end{tabular}




\section{CONCLUSÕES}

Todas as temperaturas de tratamento, utilizadas em todos os aços estudados produziram camadas com grande regularidade, que tiveram suas espessuras e durezas aumentadas com os aumentos das temperaturas de tratamento. No caso dos aços super duplex nitretados, foi verificada a formação de camadas diferenciadas sobre a ferrita e sobre a austenita. As camadas formadas sobre a ferrita foram mais suscetiveis ao ataque metalográfico, sendo atacadas com maior intensidade.

Verificou-se por meio de difração de raios $X$, a variação que ocorre nos picos da austenita ou ferrita para a formação da fase " $S$ ", responsável pelo excelente desempenho das camadas quanto à dureza, desgaste e corrosão.

Em todos os casos, ocorreu um grande aumento nas resistências ao desgaste microabrasivo das amostras nitretadas ou carbonitretadas, em comparação com o substrato, comprovando a efetividade da fase " $\mathrm{S}$ ", produzida nas temperaturas mais baixas, no aumento das durezas e resistências ao desgaste. No caso das amostras tratadas em temperaturas mais elevadas, o nitreto de cromo foi o responsável principal pelo aumento dessa resistência.

O aço inoxidável ferrítico AISI 409 nitretado ou carbonitretado apresentou os maiores niveis de durezas e de espessuras das camadas, em comparação com os aços AISI 316L e super duplex. 
Verificou-se por meio dos resultados dos ensaios de corrosão potenciodinâmicos das camadas nitretadas e carbonitretadas a $400^{\circ} \mathrm{C}$, que para os três tipos de aços em estudo, tais camadas apresentaram comportamentos semelhantes ou superiores aos dos substratos. No caso das temperaturas de tratamentos de 450 e $500^{\circ} \mathrm{C}$, as amostras carbonitretadas apresentaram desempenhos superiores aos das nitretadas e, próximos aos dos substratos, não tendo ocorrido degradação dessa propriedade mesmo com essas temperaturas mais elevadas de tratamento.

De acordo com os resultados gerais obtidos no presente trabalho, pode-se concluir que os tratamentos de nitretação a $400^{\circ} \mathrm{C}$, de todos os aços inoxidáveis estudados, foram altamente efetivos quanto ao melhoramento da resistência ao desgaste e à corrosão dos mesmos. No caso dos tratamentos de carbonitretação todas as temperaturas de tratamento produziram a melhoria dessas propriedades. A disponibilidade de tais dados indica a possibilidade de ampliação do uso desses aços para aplicações onde tais características são fundamentais. 


\section{6 - SUGESTÕES PARA TRABALHOS FUTUROS}

Estudar o efeito do tempo de tratamento de nitretação e carbonitretação por plasma sobre o mecanismo de formação das fases austenita e ferrita expandidas e suas respectivas decomposições com o aumento da temperatura de tratamento.

Determinar para os três tipos de aços inoxidáveis as temperaturas de início de formação tanto da austenita e ferrita expandidas quanto à de formação de nitretos e carbonitretos de cromo nos respectivos aços.

Estudar o mecanismo de difusão para o crescimento das camadas carbonitretadas com a variação da temperatura de tratamento. 


\section{7- REFERÊNCIAS BIBLIOGRÁFICAS}

Adachi, K.; Hutchings, I. M.. Sensitivity of wear rates in the micro-scale abrasion tes to test conditions and materials hardness. Wear, Artigo in press, p. 1-4, 2004.

Adachi, K.; Hutchings, I. M.. Wear-mode mapping for the mode-scale abrasion test. Wear, vol. 255, p 23-29, 2003.

Aksoy, M.; Kuzucu, V.; Korkut, M. H.; Yilderim, M. M.. Journal of Materials Processing Technology. 91, p. 172-177, 1999.

Aksoy, M.; V. Korkut, M. H.. Wear, vol. 211, p. 265-270, 1997.

Aksoy, M.; Yilmaz, O.; Korkut, M. H.. Wear, vol. 249, p. 639-646, 2001.

Alves JR, C.. Nitretação em plasma pulsado: equipamento preparação e caracterização das camadas nitretadas. São Carlos: UFSCar, 1995. 176p. Tese (Doutorado) - Departamento de Ciência e Engenharia de Materiais, Universidade Federal de São Carlos.

Alves Jr., D.. Nitretação a Plasma: Fundamentos e Aplicações, UFRN, 2000.

American Society for Testing and Materials.. E384-99e1: Standard Test Method for Microindentation Hardness of Materials, 2003, vol. 03.01.

American Society for Testing and Materials.. G 5: Standard reference test method for making potentiostatic and potentiodynamic anodic polarization measurements, 1991, vol. 03.02, p. 73-79.

American Society for Testing and Materials.. G 61: Standard test method for conducting cyclic potentiodynamic polarization measurements for localized corrosion susceptibility of iron-, nickel-, or cobalt-based alloys. 1994, vol. 03.02, p. 223-227.

Asphahani, A. I.; Silence, W. L.. Pitting corrosion. Metals Handbook, v. 13 corrosion, p. 113-114, 1987.

Ayala, P.; Maia da Costa, M. E. H.; Prioli, R.; Freire Jr., F. L.. Nano and micro-scale wear of fluorinated carbon films. Surface \& Coatings Technology, vol. 182, p. 335-341, 2004. 
Bell, T.; Li, C. X.. Low temperature nitriding and carburizing stainless steel. Advanced Materials \& Progress, junho de 2002.

Bell, T.. Surface engineering of austenitic stainless steel. Surface Engineering, vol. 18, n'. 6, p. 415-422, 2002.

Bian, E. C.; Griffiths, W. E.. An introduction to the iron-chromium-nickel alloys. The American Institute of Mining and Metallurgical Engineers, vol. 75, p. 166$211,1927$.

Blawert, C.; Weisheit, A.; Mordike, B. L.; Knoop, F. M.. Plasma immersion ion implantation of stainless steel: austenitic stainless steel in comparison to austenitic-ferritic stainless steel. Surface and Coatings Technology vol. $85 \mathrm{p}$. 15-27, 1996.

Blawert, C.; Kalvelage, H.; Mordike, B. L.; Collins, G. A.; Short, K. T.; Jirásková, Y.; Schneeweiss, O.. Nitrogen and carbon expanded austenite produced by $\mathrm{Pl}^{3}$. Surface and Coatings Technology vol. 136, p. 181-187, 2001.

Buzza, D. W.; Alkire, R. C.. Journal of the Electrochemical Society, vol. 142, 1995.

Chao, C. Y.; Lin, L. F.; Macdonald, D. D.. Journal of the electrochemical Society, vol. 128, p. 1187-, 1981.

Cheng, Z.; Li, C. X.; Dong, H.; Bell, t.. Low temperature plasma nitrocarburising of AISI 316 austenitic stainlessw steel. Surface \& Coatings Technology. Artigo in press, 2004.

Czerwiec, T.; Renevier, N.; Michel, H.. Low-temperatura plasma-assisted nitriding. Surface and Coatings Technology, v. 131, p. 267-277, 2000.

Davis, J.R.. (Editor): ASM Speciality Handbook: Stainless Steel, p. 13-65, ASM International, Materials Park, Ohio, 1994.

Dearnley, P. A.. Corrosion wear response of "S" coated 316L. Surface Engineering, vol. 18, $n^{\circ} 6$, p.429-432, 2002.

Denton, Rod. S.. Ion nitriding vs chrome plating for automotive fender dies. Heat Treatment, vol. 22, ํo. 8, p. 20-23, 1990.

Edenhofer B.. Production ionitriding. Metals Progress, vol. 109, n‥ 3, p. 38-42, 1976.

Edenhofer, B.. Physical and metallurgical aspects of ion nitriding, Heat Treatment of Metals, vol. 1 p. 59-67, 1974.

Eyre, T. S. Wear characteristics of metals. In: Source book or wear control technology. Metals Park Ohio, American Society for Metals. p. 1-10, 1978.

Fewell. M. P; Priest, J. M.; Baldwin, M. J.; Collins, G. A.; Short, K. T.. Nitriding at low temperature. Surface and Coatings Tecnology, v. 131, p. 284-290, 2000-(a). 
Fewell. M. P; Mitchell, D. R. G.; Priest, J. M.; Short, K. T; Collins, G. A.. The nature of expanded austenite. Surface and Coatings Tecnology, v. 131, p. 300-306, 2000-(b).

Fontana, M. G.; Greene, N. D.. Corrosion engineering. Mcgraw-hill, 555p, 1987.

Frankel, G. S.; Stockert, L.; Hunkeler, F.; Boehni, H.. Metastable pitting of stainless steel. Corrosion, Houston, vol. 43, nº.7, 1989.

Galvele, J. R.. Corrosion Science, vol. 21, 1981.

Gates, J. D.. Two-body and three-body abrasion: a critical discution. Wear, v. 214, p.139-146, 1998.

Gemma, K. and Kawakami, M.. Enhancement of nitriding rate in SUS304 austenitic stainless steel under gas nitriding. High Temp. Mater. Processes. Vol. 8, n‥ 4, p205-216, 1989.

Gemma, K.; Satoh, Y.; Ushioku, I.; Kavakami, M.. Abnormal nitriding behaviour of a high chromium, high manganese austenitic steel, Surface Engeneering, vol.11, p. 240-245, 1995.

Greene, Joseph M.. Introduction to glow discharge plasma processes. Metal Heat Treating. vol. 4, p23-24, 1994.

Grün, R.; Güther, H.. Plasma nitriding in industry, problems, new solutions 37nd limits. Materials Science and Engineering, A140, p. 435-441, 1991.

Hansen, M.. Metallurgy and metallurgycal engineering series. MacGraw-Hill Book Company, p. 671, 1958.

Honeycombe, R. W. K.. Aços - microestrutura e propriedades. Fundação Calouste Gulbenkian, 1985.

Hudis, M.. Study of ion nitriding. Journal of Applied Physics, vol. 44, n 4, p. 148996, 1973.

Ichii, K.; Fujimura, K.; Takase T.. Structure of the ion-nitrided layer of 18-8 stainless steel. Technol. Rep. Kansi Univ. n. 27, p. 135-144, 1986.

Jack, K. H.. The iron-nitrogen system: the crystal structures of $\varepsilon$-phase iron nitrides. Acta Crystallographica, v. 5, p. 404-411, 1952.

Jack, D. H.; Jack, K. H.. Carbides and nitrides in steel. Materials Science and Engineering, v. 11, p. 01-27, 1973.

Jánosi, S.; Kolozsvary, Z.; Sándor, V.; Rusu, A.. A few remarks on plasma nitriding behavior of austenitic and martensitic stainless steels. In: 20th ASM Heat Treating Society Conference Proceedings, 9-12 October (2000), p. 198-207.

Jones, C. K.; Martín, S. W.; Hudis, M.. Ion Nitriding. In: The Metals Society Proceedings Conference - Heat Treatment, London, p. 71-77, 1973. 
Kliauga, A. M.. A layer grow mechanism proposed on studies on a gas nitrided AISI 316L austenitic stainless steel. Steel Research, vol. 69, p. 102-106, 1998.

Krainer, H.. Krupp Techn. Mitt. 20, p.165-179, 1962. In: Pohl, M. The ferrite/austenite ratio of duplex stainless steels. Z. Metallkd, vol. 86, p. 97-102, 1995.

Ku, J. S.; HO, N. J.; Tjong, S. C.. Properties of electron beam welded SAF 2205 duplex stainless steel. Journal of Materials Processing Tecnology, vol. 63, p. 770-775, 1997.

Kusano, Y.; Acker Van, K.; Hutchings, I. M.. Methods of data analysis for the microscale abrasion test on coated substrates. Surface and Coatings Technology, v. 183, p. 312-327, 2004.

Kuzucu, V.; Aksoy, M.; Korkut, M. H.. Journal of Materials Processing Technology, vol. 82, p. 165-171, 1998.

Lampe, T.; Eisenberg, S.; Laudien, G.. Compound layer formation during plasma nitriding and plasma nitrocarburising. Surface Engineering, vol. 9, no. 1, p. 6976, 1993.

Larisch, B.; Brusky, U.; Spies, H. -J.. Plasma nitriding of stainless steels at low temperatures. Surface and Coatings Technology, vol. 116-119, p. 205-211, 1999.

Laycock, N. J.; Newman, R. C.. Localised dissolution kinetics, salt films and pitting potentials. Corrosion Science, vol. 39, n². 10-11, p 1771-1979, 1997.

$\mathrm{Li}, \mathrm{X}$. Y.. Low temperature plasma nitriding of 316 stainless steel-nature of "S" phase and its thermal stability. Surface Engineering, vol. 17, $n^{\circ}$. 2, p. 147-152, 2001.

$\mathrm{Li}, \mathrm{X}$. Y.; Haiwatthana, S.; Dong, T. H. and Bell, T.. Thermal stability of carbon "S" phase in 316 stainless steel. Surface Engineering, vol.18, $n^{\circ} .6,2002$.

Liang, W.; Bin, X.; Zhiwei, Y.; Yaqin, S.. The wear corrosion properties of stainless steel nitrided by low-pressure plasma-arc ion nitriding at low temperature. Surface and Coatings Technology, vol. 130, p. 304-308, 2000.

Menthe, E.; Rie, K. T.; Schultze, J. W.; Simson, S.. Structure and properties of plasma nitrided stainless steel. Surface and Coatings Technology, vols.74-75 p. 412-416, 2000.

Menthe, E.; Rie, K. T.. Further investigation of the structure and properties of austenitic stainless steel after plasma nitriding. Surface and Coatings Technology. vols. 116-119, p. 199-204, 1999.

Mittermmeijer, E. J.; Sommers, M. A. J.. Layer growth kinetics on gaseous nitriding of pure iron: evalution of diffusion coefficients for nitrogen in iron nitriding. Metallurgical and Materials Transactions A, vol. 26A, p. 57-74, 1995.

Moustafa, I. M.; Moustafa, M. A.; Nofal, A. A.. Materials Letters, vol. 42, p. 371$379,2000$. 
Newman, R. C.. The dissolution and passivation kinetics of stainless.

Nilsson, J. O.. Super duplex stainless steel. Science and Technology, vol. 8, p. 685-699, 1992.

O'brien, J.; Goodman, D.. Plasma (ion) nitriding. In: AMERICAN SOCIETY FOR METALS. Heat Treating. Ohio (ASM Handbook, 4) p. 420-424, 1991.

Padilha, A. F.; Guedes, L. C.. Aços inoxidáveis austeníticos: microestrutura e propriedades, Hemus Editora Ltda, São Paulo, 1994.

Pohl, M.. The ferrite/austenite ratio of duplex stainless steels. Z. Metallkd, vol. 86, p. 97-102, 1995.

Pranevicius, L. Templier, C.; Rivière, J. P.; Méheust, P.; Pranevicius, L. L.; Abrasonis, G.. On the mechanism of ion nitriding of an austenitic stainless steel. Surface and Coatings Technology, vol. 135, p. 250-257, 2001.

Pye, D.. Ion nitriding of holes and cavities using a combination of variable pressure control and power pulsation techniques. In: International Heat treating conference equipment and processes. ASM Anais, Ohio, p. 353-359, 1994.

Pye, D.. Pulsed plasma ion nitriding and control of the compound zone (or white layer). In: $2^{\text {nd }}$. INTERNATIONAL CONFERENCE ON CARBURIZING AND NITRIDING WITH ATMOSPHERES, Cleveland, Ohio, December 95, p. 315-321 1995.

Ramanathan, L. V.. Corrosão e seu controle. Hemus Editora Ltda., 339p, 1989.

Reick, H.; Pohl, M.; Padilha, A. F.. O desenvolvimento dos aços inoxidáveis ferríticos-austeníticos com microestrutura duplex. Metallurgla \& Materlals ABM, vol. 48, n. 409, p. 551-563, 1992.

Rembges, W.. Fundamentals, applications and economical considerations of plasma nitriding. In: ASM International Conference on Ion Nitriding. Anais, Cleveland, Ohio, USA, Sept, 1986. p. 189-198, 1987.

Rie, K. T.. Current status of plasma diffusion treatment technique and trends in new application In: INTERNATIONAL CONFERENCE ON ION NITRIDING/CARBONITRIDING, 2, Cincinnati, 1989. Procedings, Materials Park, ASM International, p. 45-54, 1989.

Rouby, M.; Blancharf, P.. Physical and mechanical properties of stainless steels (Chapter 4). In: Stainless Steel, Lacombe, P. Baroux, B.; Beranger, G. (Scientific Editors), p. 109-160, Les Editions de Physique, France, 1993.

Rozendaal, H. C. F.;Mittemeijer, E. J.; Colijn, P. F.; Van der Schaaf, P.J.. The development of nitrogen concentration profiles on nitriding iron. Metallurgical Transactions, vol. 14A, p. 395-399, 1983.

Rucet, C.. Influence of pressure on temperature uniformity in the plasma nitriding process. Heat Treatmente of Metals, p. 81-84, 1991. 
Rutherford, K. L.; Hutchings, I. M.. A micro-abrasive wear test, with particular application to coated systems. Surface and Coatings Technology, vol. 79, p. 231-239, 1996.

Rutherford, K. L.; Hutchings, I. M.. Theory and application of a micro-scale abrasive wear test. Journal of Testing and Evaluation, vols. 25 e 2, p. 250-260, 1997.

Sedriks, A. J.. Corrosion of stainless steels. 2a ed., A. Wiley, Interscience Puplication, 1996.

Shipway, P. H.. The role of test conditions on the microabrasive wear behaviour of soda-lime glass. Wear, vol.233-235, p. 191-199, 1999.

Solomon, H. D.; Devine, Jr. T. M.. Duplex stainless steels - A tale of two phases. ASM, Metals Park, Ohio (R. A. Lula ed.), p. 693-756, 1982.

Spalvins, T.. Tribological and microstructural characteristics of ion-nitreded steel.In: INTERNATIONAL CONFERENCE ON METALLURGYCAL COATINGS. Anais, San Diego, USA, p. 157-163, 1983.

Sun, Y.; Bell, T.;Colosvary, Z.;Flis, J.. The Response of Austenitic Stainless Steels to Low-temperature Plasma Nitriding. Heat Treatment of Metals. vol. 01, p. 9161999.

Sun, Y.; Bell, T.. A numerical model of plasma nitriding of low alloy steels, Materials Science and Engeneering A, vol. 224, p. 33-47, 1997.

Sun, Y.; Li, C. X.; Bell, T.. Low temperature plasma carburising of austenitic stainless steels for improved wear and corrosion resistance. Surface Engineering, v. 15, p. 49-54, 1999.

Szklarska-Smialowaka, Z.. Pitting corrosion of aluminum. Corrosion science, vol. 41, p. 1743-1767, 1999.

Szklarska-Smialowska, Z.. Mechanism of pit nucleation by electrical breakdown of the passive film. Corrosion Science, vol. 44, p. 1143, 2000.

Thaiwatthana, S.; Li, X. Y.; Dong, H.; Bell, T.. Comparison studies on properties of nitrogen and carbon "S" phase on low temperature plasma alloyed AISI 316 stainless steel. Surface Engineering, vol.18, $n^{\circ} .6,2002$.

Tibbetts, G.G. Role of nitrogen atoms in ion nitriding. Journal of Applied Physics, vol. $45, n^{\circ} .11$, p. $5072-3,1974$.

Torchane, L.; Bilger, P.; Dulcy, J.; Gantois, M.. Control of iron nitride layers growth kinetics in the binary Fe-N system, Metallurgical and Materials Transactions, vol. 27A, p. 1823-1835, 1996.

Trezona, R. I.; Allsopp, D. N.; Hutchings, I. M.. Transitions between two-body and three-body abrasive wear: influence of test conditions in the microscale abrasive wear test. Wear, vols. 225-229, p. 204-214, 1999. 
Trezona, R. I.; Hutchings, I. M.. Three-body abrasive wear testing of soft materials. Wear, vols. 233-235, p. 209-221, 1999.

Tsujikawa, M.; Yamauchi, N.; Ueda, N. Sone, T.; Hirose, Y.. Behavior of carbon in low temperature plasma nitriding layer of austenitic stainless steel. Surface \& Coatings Technology, (2004), in press.

Uhlig, H. H.. Metals Handbook, vol. 13, corrosion, p. 113, 1987.

Vatavuk, J.; Vendramin, J. C.; Bloem Silveira Jr., L. A.. Estudo comparativo entre os processos de nitrocarbonetação em banho de sal e por plasma para aplicação em êmbolos. Society of Automotive Engineers, 2000.

Zhang, Z. L.; Bell, T.. Structure and corrosion resisrtance of plasma nitrided stainless steel. Surface Engineering. vol. 1, ํㅜ. 2, p. 131-136, 1985.

Zhu, X.; Huang, H.; Xu, K.; He, J.. Structure and properties of plasma nitrided austenitic stainless steel. In: 20th ASM Heat Treating Society Conference Proceedings, 9-12 October, p. 217-221, 2000. 


\section{8- TRABALHOS PUBLICADOS}

\section{I - ARTIGOS COMPLETOS PUBLICADOS EM PERIÓDICOS}

A. M. de Oliveira; R. M. Munöz Riofano; L. C. Casteletti; G. F. Tremiliosi e C.A.S. Bento. Effect Of the Temperature of Plasma Nitriding in Aisi 3161 Austenitic Stainless Steel. Revista Brasileira de Aplicações de Vácuo, v. 22, $n^{\circ}$ 2, p. 63-66, 2003.

FREITAS BATISTA, S. R.; OLIVEIRA, A. M.; KURI, S. E. Aspects of the metallographic preparation of duplex stainless steels for analysis by optical microscopy. Acta Microscópica, supplement A, vol. 1, p. 221-222, 2002.

\section{II - TRABALHOS COMPLETOS PUBLICADOS EM ANAIS DE EVENTOS}

OLIVEIRA, Antonio Maia de, CASTELETTI, L. C., RIOFANO, Rosamel Melita Munõz.Avaliação da resistência ao desgaste e à corrosão de aços inoxidáveis ferríticos com $\mathrm{Nb}$ nitretados por plasma In: $59^{\circ}$. Congresso Anual da ABM Internacional, 2004, São Paulo, SP. Anais DO 59 . Congresso Anual da ABM Internacional. São Paulo, SP: ABM, 2004. v. CD-ROM. p. 4015 - 4023.

OLIVEIRA, Antonio Maia de, CASTELETTI, L. C., RIOFANO, Rosamel Melita Munõz. Influência da nitretação por plasma na resistência à corrosão e ao desgaste do aço inoxidável austenítico AISI 316L In: 59 . Congresso Anual da ABM - Internacional, 2004, São Paulo, SP.Anais DO 59. Congresso anual da ABM - Internacional. São Paulo, SP: ABM, 2004. v. CD-ROM. p. 3995 - 4004. 
OLIVEIRA, Antonio Maia de, CASTELETTI, L. C. A qualidade metalográfica In: Congresso de Pós-Graduação em Ciência e Engenharia de Materiais, 1992, 1992, São Carlos, SP.Anais do Congresso de Pós-Graduação em Ciência e Engenharia de Materiais,. São Carlos, SP: FAPESP/ CNPq/RHAE/UFSCar, 1992. p. $317-320$.

III - TRABALHOS RESUMIDOS PUBLICADOS EM ANAIS DE EVENTO

OLIVEIRA, Antonio Maia de, CASTELETTI, L. C., RIOFANO, Rosamel Melita Munõz. Avaliação da resistência ao desgaste e à corrosão de aços inoxidáveis ferríticos com $\mathrm{Nb}$ nitretados por plasma In: $59^{\circ}$. Congresso Anual da ABM Internacional, 2004, São Paulo, SP. Resumos do $59^{\circ}$. Congresso Anual da ABM - Internacional. São Paulo, SP: ABM, 2004. p. 65-65.

OLIVEIRA, Antonio Maia de, CASTELETTI, L. C., RIOFANO, Rosamel Melita Munõz. Influência da nitretação por plasma na resistência à corrosão e ao desgaste do aço inoxidável austenítico AISI $316 \mathrm{~L}$ In: $59^{\circ}$. Congresso anual da ABM - Internacional, 2004, São Paulo, SP. Resumos do 59 . Congresso Anual da ABM - Internacional. São Paulo, SP: ABM, 2004. p. 152- 152.

OLIVEIRA, Antonio Maia de, RIOfANO, Rosamel Melita Munõz, CASTELETTI, L. C. Efeito da temperatura de nitretação por plasma em aço inoxidável austenítico In: XXIV Congresso Brasileiro de Aplicações de Vácuo na Indústria e na Ciência, 2003, Bauru, SP. Programa Oficial Congresso Brasileiro de Aplicações de Vácuo na Indústria e na Ciência. Bauru, SP: UNESP, 2003. p. $132-132$.

OLIVEIRA, Carlos Kleber Nascimento de, OLIVEIRA, Antonio Maia de, RIOFANO, Rosamel Melita Munõz, CASTELETTI, L. C. Influência da microestrutura na nitretação iônica do aço AISI D2 In: XXIV Congresso Brasileiro de Aplicações de Vácuo na Indústria e na Ciência, 2003, Bauru, SP. Programa Oficial XXIV Congresso Brasileiro de Aplicações de Vácuo na Indústria e na Ciência. Bauru, SP: UNESP, 2003. p. 95 - 95. 
SOUFEN, Carlos Alberto, CASTELETTI, L. C., OLIVEIRA, Antonio Maia de. Nitretação iônica de aços fundidos grafíticos austemperados ao nióbio In: XXIV Congresso Brasileiro de Aplicações de Vácuo na Indústria e na Ciência, 2003, Bauru, SP. Programa Oficial do XXIV Congresso Brasileiro de Aplicações de Vácuo na Indústria e na Ciência. Bauru, SP: UNESP, 2003. p. 62 - 62.

CASTELETTI, L. C., OlIVEIRA, Antonio Maia de, RIOFANO, Rosamel Melita Munõz. Estudo da resistência ao desgaste abrasivo no aço inoxidável ferrítico solubilizado nitretado por plasma In: XV Congresso Brasileiro de Engenharia e Ciências dos Materiais, 2002, Natal, RN. Resumos. Natal, RN: PDCEMUFRN, 2002. v. CD ROM.

CASTELETTI, L. C., OLIVEIRA, Antonio Maia de. Nitretação iônica de camadas metálicas depositadas em aços In: IV Simpósio Interunidades em Ciência e Engenharia de Materiais, 2001, São Carlos, SP. Resumos do IV Simpósio em Ciência e Engenharia de Materiais. São Carlos, SP: EESC/IFSC/IQSC, 2001. p. $143-144$.

\section{IV - TRABALHOS RESUMIDOS EXPANDIDOS PUBLICADOS EM ANAIS DE EVENTO}

OLIVEIRA, Antonio Maia de, CASTELETTI, L. C. Microestrutura e propriedade de camadas nitretadas por plasma nos aços inoxidáveis ferríticos AISI $430 \mathrm{E}$ e 441 In: VI Simpósio Interunidades em Ciência e Engenharia de Materiais, 2003, São Carlos, SP. Resumos do VI Simpósio Interunidades em Ciência e Engenharia de Materiais. São Carlos, SP: IQSC/USP, 2003. p. $119-120$.

OLIVEIRA, Antonio Maia de, RIOFANO, Rosamel Melita Munõz, CASTELETTI, L. C., TREMILIOSI FILHO, Germano, BENTO, Carlos Alberto da Silva. Microstructural analysis of the ion nitrided layer of the ferritic stainless steel AISI 439 In: XIX Congresso da Sociedade Brasileira de Microscopia e Microanálise, 2003, Caxambu, MG. Anais do XIX Congresso da Sociedade Brasileira de Microscopia e Microanálise. Rio de Janeiro, RJ: UFRJ/SBMM, 2003. v. CR ROM. 
OLIVEIRA, Antonio Maia de, CASTELETTI, L. C. Influência da pressão de nitretação por plasma na obtenção de camadas nitretadas em aços inoxidáveis ferríticos In: V Simpósio Interunidades em Ciência e Engenharia de Materiais, 2002, São Carlos, SP. Resumos do V Simpósio em Ciência e Engenharia de Materiais. São Carlos, SP: IFSC/USP, 2002. p. $135-136$. 